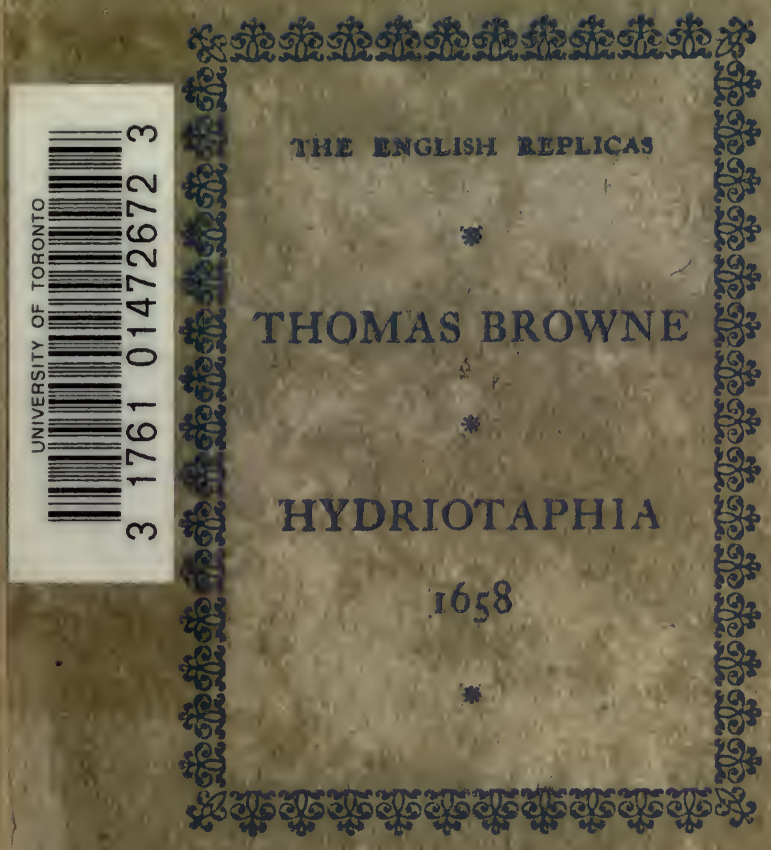










\section{Desesh}

\section{(THE ENGLISH REPLICAS) Sir THOMAS BROWNE HYDRIOTAPHIA}

THEOCTAVOEDITIONOF BROWNE's Hydriotaphia I 658 WAS FOLLOWED IN THE SAME YEAR BY A SECOND EDITION WHICH APPEARED IN QUARTO TOGETHER WITH THE FOURTH EDITION OF Pseudodoxia Epidemica - Urne Buriall AND The Garden OF Cyrus ARE INCLUDED IN THE EDITIONS OF THE Pseudodoxia OF 1659 AND I 669 AND IN ALL SUBSEQUENT COLLECTED EDITIONS OF BROWNE'S WORKS - THE SECOND SEPARATE EDITION APPEARED IN 1736 AND IS EVEN SCARCER THAN THE FIRST WHICH IS REPRODUCED HERE FROM A COPY IN THE BRITISH MUSEUM - FOR DETAILED INFORMATION ABOUT THIS AND LATER EDITIONS OF THE BOOK KEYNES' Bibliograpby OF sir 'Thomas

Browne CAMBRIDGE I924 SHOULD BE CONSULTED

THIS BOOK

IS NOW PUBLISHED IN THE UNITED STATES

BY COLUMBIA UNIVERSITY PRESS

FOR

THE FACSIMILE TEXT SOCIETY

2960 BROADWAY, NEW YORK, N. Y.

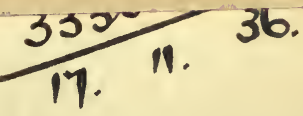





\section{berish}

\section{(THE ENGLISH REPLICAS) Sil THOMAS BROWNE HYDRIOTAPHIA}

THE OCTA VO EDITIONOF BROWNE'S Hydriotaphia I6 58 WAS FOLLOWED IN THE SAME YEAR BY A SECOND EDITION WHICH APPEARED IN QUARTO TOGETHER WITH THE FOURTH EDITION OF Pseudodoxia Epidemica - Urne Buriall AND The Garden OF cyrus ARE INCLUDED IN THE EDITIONS OF THE Pseudodoxia OF 1659 AND I 669 AND IN ALL SUBSEQUENT COLLECTED EDITIONS OF BROWNE'S WORKS - THE SECOND SEPARATE EDITION APPEARED IN 1736 AND IS EVEN SCARCER THAN THE FIRST WHICH IS REPRODUCED HERE FROM A COPY IN THE BRITISH MUSEUM - FOR DETAILED INFORMATION ABOUT THIS AND LATER EDITIONS OF THE BOOK KEYNES' Bibliograpby OF sir Thomas Browne CAMBRIDGE 1924 SHOULD BE CONSULTED

1927

Payson of clarke Ltd

New York

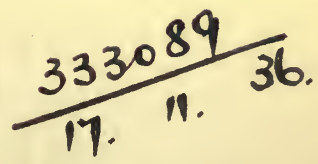




\section{927 \\ MADE AND PRINTED IN ENGLAND BY PERCY LUND, HUMPHRIES \& CO. LTD. BRADFORD AND LONDON}





$$
\begin{aligned}
& P R \\
& 3327 \\
& A 65 \\
& 1658 a
\end{aligned}
$$


-

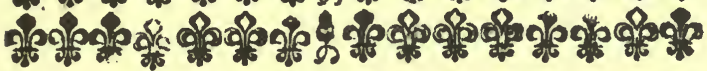

\section{TO MY}

Worthy and Honoured Friend

\section{THOMAS Le GROS of Croftwick Efquire.}

Hen the Funerall pyre was
out, and the laft valedi-
cion Over, men took a
lafting adieu of their in-
terred Friends, little expecting the curiofity of furure ages fhould comment upon their alhes, and having no old experience of the duration of their Reliques, held no opinion of fuch after confiderations.

But who knows the fate of his bones, or how ofren he is to be buried? who Pompeics hath the Oracle of his alhes, or whether juvenes $A$ they are to be feattered? The Reliques Europa.fed of many lie like the ruines of 2 Pompeys,

$$
\mathrm{A}_{2} \text { in }
$$
t: it Lybitso 


\section{The Epistle}

in all parts of the earth; And when they arrive at your hands, thefe may feem to have wandred far, who in a di. - Little di- rect $\mathrm{b}$ and Meridian Travell, have but rectly, but Sea be-

houle ad Greenland. - Brought back by Cimon. Plutarch.

That the bones of The feas fhould be feen ag in $c$ in Atbers, was not beyond conjecture, and hopeful expectation; but that thefe thould arile fo opporcunely to ferve your felf, was an hit of fate and honour beyond prediction.

We cannot but with thefe Urnes might have the effect of Theatrical veffels, and - The great great d Hippodrome Urnes in Rome ; to reurnes in found the acclamations and honour due the Hippodrome at Rome conceived to refound the voices of people at their thows - Worthily poffeffed by that true Genrleman Sir Horatio Townsbend any honored Friend. onto you. But thefe are fad and fepulchral Pitchers, which have no joyful voices; filently expreffing old mortality, the ruines of forgotten times, and can only fpeak with life, bow long in this corruptible frame, fome parts may be uncorrupted; yet able to out-laft bones long unborn, and nobleft pyle $\mathrm{e}^{\mathrm{among}} \mathrm{us.}$

We prefent not thefe as any ftrange fight or fpectacle unknown to your eyes, who have beheld the beft of Urnes, and nobleft 


\section{Dedicatory.}

nobleft variety of Afhes; Who are your felf no flender mafter of Antiquities, and can daily command the view of fo many Imperiall faces; Which raifeth your thoughts unto old things, and confideration of imes before you, when cven living men were Antiquities; when the living might exeeed the dead, and to depart this world, could not be properly faid, to go unto the $f$ greater number. ' $\mathrm{f}$ Abit ad And fo run up your thoughts upon the plures. ancient of dayes, the Antiquaries trueft object, unto whom the eldeft parcels are young, and earth it felf an Infant ; and without $\mathrm{g}$ \&gyptian account makes but fmall noife in thoufands.

We were hinted by the occafion, not catched the opportunity to write of old 6 Which makes the world fo many years old. things, or intrude upon the Antiquary. We are coldly drawn unto difcourfes of Antiquities, who have fcarce time before us to comprebend new things, or make out learned Novelties. But feeing they arofe as they lay,almoft in filence among us, at leaft in fhort account fuddenly paffed over; we were very unwilling they fhould die again, and be buried twice among us.

A 3

Befide 


\section{The Epiftle}

Befide, to preferve the living, and make the dead to live, to keep men ont of their Urnes. and difoourfe of humane fragments in them, is not impertinent uneo our profeffion; whofe ftudy is life and death, who daily behold examples of mortality, and of all men leaft need artificial mensento's, or coffius by our bed fide, to minde us of our graves.

'Tis time to obferve Cccurrences, and let nothing remarkable efcape us; The Supinity of elder dayes hath left fo much in filence, or time hath fo martyred the

wherein

M. Dugdale hath excel. lently well endeavoured, and worthy to be countenanced by ingenuous and noble perfons.

Records, that the moft $h$ induftrious heads do finde no eafie work to erect a new Britannia.

'Tis op portune to look back upon old times, and contemplate our Forefathers. Great examples grow thin, and to be fetched trom the paffed world. Simplicity flies away, and iniquity comes at long ftrides upon us. We have enough to do to make up our felves from prefent and paffed times, and the whole ftage of things fearce ferveth for our inftruction. A compleat peece of vertue muft be made up from the Centes of all ages, as 


\section{Dedicatory,}

as all the beauties of Greece could make but one handfome Venws.

When the bones of King Arthur were digged up $i$, the old Race might think, iIn the time they beheld therein fome Originals of of Henny themfelves; Unto thefe of our Urnes none here can pretend relation, and can only behold the Reliques of thofe perfons, who in their life giving the Laws unto their predeceffors, after long obfcurity, now lye at their mercies. But remembring the early civility they brought upon thefe Countreys, and forgetting long paffed mifchiefs; We mercifully preferve their bones, and piffe not upon their athes.

In the offer of thele Antiquities we drive not at ancient Families, fo long out-lafted by them; We are farre from erecting your worth upon the pillars of your Fore-fathers, whofe merits you illuftrate. We honour your old Virtues, conformable unto times before you, which are the Nobleft Armoury. And having long experience of your friendly converfation, void of empty Formality, full of freedome, conftant the fecond, Cambden. 


\title{
The Epiftle, \&c.
}

- Adamess de and Generous Honefty. I look upon rupe veteri you as a Gemme of the k Old Rock, and mrefantiffr. muft profefie my felf evento Urne and Alhes,

Nanvich

May Is.

\section{Your ever faithfull Friend,}

\author{
and Servant,
}

Thomas Brosone.
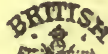

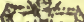

(n)

79.5

isEorit 


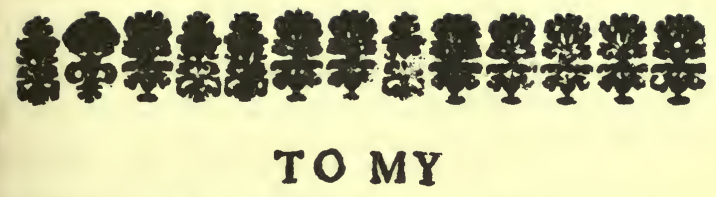

\section{Worthy and Honored Friend}

\section{$\mathcal{N}$ ICHOLAS BACON of Gillingbam Efquire.}

Id I not obferved that a Pur- Plempius,

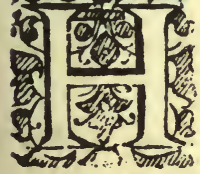
blinde mern bave difcourfed Cabems, \&c: well of light, avd Some b with- $b$ D.Haray. out iffue, excellertly of Generotion; I that was never magiter of any confederable garden, had not attempsed this Subject. Bat the Earth is the Garden of Nature, and each fruitfull Cousatrey a Paradife. Diofcorides made most of his Obfervations in bis march about with Antonius; and Theophraftus raiJed bis generaluties chrefly from the field.

Befsic we wortte no Herball, nor can this . Befleri Volwose deocive you, who bave bandled the Hortus Eyc maffeeft tbereof: who know that three fetenfis. a Folio's are yet too little, and bow New Meatrum Herbals fly from America upon us, from Boranicum, per\&c. 


\section{The Epitte}

- Mywor. perfevering Enquirers, and c old in thole thy friend fingularities, noe expect /uch Defcriptions. an ancient Wherein f England is now fo exact, that it

and learned yeelds not to orber Countreys.

FAs in Lon. dan and di- fons by Quincuncial and Reticulate plants; whereof we or ereat a new Phytology. The Field of mention knowledge batbleen fo traced, it is bard to none, left pring any thing new. Of old tbings we omitany. write formetbing uew, if trutb may receive addition, or envy wall bave any tbing new; fence the Ancients knew the late Analomicall difcoveries, and Hippocrates the Circulation.

rou bave been fo long out of trite learn. ing, that 't is bard to finde a Jubject proper for you; and if you bave met with a shees upon this, we bave mifjed our intention. In this multiplicity of writing, bye and barren Tbemes are beft fitted for invention; Sub. jects fo ofien difcourfed confire the Imagination, and fix our conceptions whto the notions of fore-moriters. Befide, /uch Difcour(es allow excurfions, and venially admit of colla. terall trutbs, though at fome difasice from - Hippocrates their principals. Wherein if we fometimes de Superfeetatione, de dentitione. take wide liberty, we are not fingle, bus erre by great $g$ example. 


\section{Dedicatory.}

He that will illufirate the excellency of this order, wray enfly fail upon so proce a Subjert, wherein we bave not affrighted the commone Reader with any otber Diagramms, then of it felf; and bave induftrioufly declined illhfrations from rare and unknoson plants.

Your difcerning judgement fo well acquairsted with thas ftudy, woill expect berein no matbematicall trutbs, is well underftanding bow feen generalities and $\mathrm{h} V$ finita's there are in natare. How Scaliger bath found exceptions in moft Univerfals of Ariftotle and

$\rightarrow$ Rules without exceptions.

Theophraftus. How Botanicall Maximes muft bave fair allowosnce, and are toler abb surrant, if not intolerably over-ballanced by exceptions.

You have wifely ordered your vegetable delights, beyond the reach of exception. The Twrks woho pafft their dayes in Gardens here, will bave Gardens alfo bereafier, and delighting in Flowers on earth, mujt bave Lillies and Rofes in Heaven. In Garden Delighes 'tis not eafie to bold a Mediocrity; that infinuat ing pleafure is Seldome without fome extremity. The Antients venially delighted in flourifbing Gardens; Many woere Florifts that knew not the true use of a Flower; And in Plinies dayes none bad directly trea- 


\section{The Epifte}

ted of that subject. Some commendably affected Plantations of venemows Vegetables, Jome confined their delights unso fingle plants, and Cato/eemed to dote upon Cabbadge; Whale the Irgennous delight of Twlipifts, ftands faluted roith bard language, e-

i Tulipomamia, Narrencrurid, Lau. renberg.Pst. Hondius. in Jib. Belg. ven by their own i Profefors.

That in this Garden Difconr $\int e$, we range into extraneous things, and muny parts of Art an 2 Cature, we follow herein the example of old and new Plantations, wherein noble $\beta$ erits contented not themfelves mith Trees, but by the attendance of Aviaries, Fifl Ponds, and all variety of Animals, thcy made their gardens the Epitome of the earth, and fome refembiance of the Secular bows of old.

That we conjoyn the $\int e$ parts of aifferent subjects, or that this fhoild fucceed the ather; Your judgem:nt wall adnoit woithout impure of incongruity; since the delightfull world comes after death, and Paradife fucceeds tbe Grave. Since the verdant pate of tbings is the Symbole of the Refurrection. and to flowith in the fate of Glory, ne muft firft be fown in corrupsion. Befold the anciess practife of 2 Koble Perfons, to conclue in Garden-Graves, and Vrnes themf:lises of old. 


\section{Dedicatory.}

old, to be wrapt up flowers and garlaseds.

Nullum fine venia placuiffe eloquium, is more Senfibly underflood by Writers, then by Readers; nor well apprebended br eitber, till works bave bang? Pidures; wherein even common eyes will firsde fosset bing for emendation.

To woifh all Readers of your abilities, soere nnreafonably to multiply the number of Scholars beyond the temper of thefe times. But weto tbis ill-judging age, we charitably defire a portion of your equity, judgement, canzdour, and ingensity ; wherein you are fo rich, as not to lose by diffufson. And being a flouri|Jing branch of that $\mathrm{k}$ Noble Family, unto k of the wobich soe owe fo much obfervance, you are not new fet, but long rooted in jacb perfections whereof baving bad fo lasting confirmation in your wort by converfation, const anet amity, and expreffion; and knowing you a $S_{2-}$ vious student in the bigbeft arcana's of $\mathrm{Na}$ moft worthy Sr Ed. mund Bacon prime Baronet, my true and noble Friend. ture; with much excuse roe bring thefe low delights, and poor maniples to your Treafure. Norwicb May I.

Your affectionate Friend and Servant,

\section{Thomas Browne.}




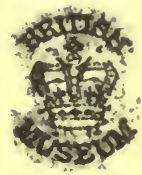




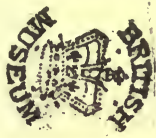

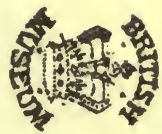




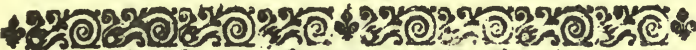

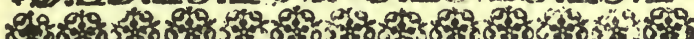

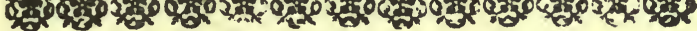

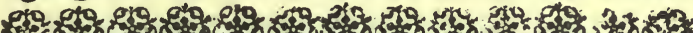

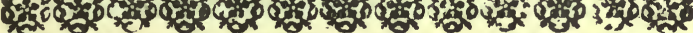

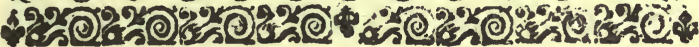

\section{HY D R IOT A PHI A}

Vrne-Buriall.

OR,

A Brief Difcourle of the $\mathrm{Se}$ pulchrall Urnes lately found in NOR FOL K.

CHAPTER I.

- $\mathrm{N}$ the deep difcovery of the

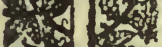
Subterranean world, a thallow part would fatisfie fome enquirers; who, if two or three yards were open about the furface, would not care to rake the bowels of $p:-$ tog 8 a, and regions towards the Centre. 
Nature hath furnilhed one part of the Earth, and man another. The treafures of time lie high, in Urnes, Coynes, and Monuments, fearce below the roots of fome vegetables. Time hath endleffe rarities, and hows of all varieties; which reveals old things in heaven, makes new difcoveries in earth, and even earth it felf a difcovery. That great Antiquity America lay buried for a thoufand years; and a large part of the earth is fill in the Urne unto us.

Though if Adam were made out of an extract of the Earth, all parts might challenge a reftitution, yet few have returned their bones farre lower then they might receive them; not affetting the graves of Giants, under billy and heavy coverings, but content with leffe then their owne depth, have wilhed their bones might lie fofe, and the earth be light upon them; Even fuch as hope to rile again, would not be contenr with centrall interrment, or fo defperately to place their reliques as to lre beyond difcovery, and in no way to be feen again; which happy contrivance hath made communication with our forefachers, 
thers, and lefe unto our view fome parts, which they never beheld themfelves.

Though earth hath engroffed the name yet water hath proved the Imarteft grave; which in forty dayes fwallowed almoft mankinde, and the living creation; Fithes not wholly efcaping, except the Salt Ocean were handfomely contempered by a mixture of the frefh Element.

Many have taken voluminous pains to determine the ftate of the foul upon difanion; but men bave been moft phantaficall in the fingular contrivancss of their corporall diffolution: whileft the fobreft Nations have refted in two wayes, of fimple inhumation and búrning.

That carnall interment or burying, was of the elder date, the old examples of Abrabam and the Patriarchs are fufficient to illuftrate; And were without competition, if it could be made out, that $A$ dam was buried near Damafcus, or Mount Calvary, according to fome Tradition. God himfelf, that buried but one, was pleafed to make choice of this way, collectible from Scripture-exprefion, and the

B 2

hot 


\section{Hydriotaphia,}

hot conteft between Satan and the ArchAngel, about difcovering the body of Moofes. But the practice of Burning was alfo of great Antiquity, and of no lender extent. For (not to derive the fame from Hercules) noble defcriptions there are hereof in the Grecian Funerals of Homer, In the formall Obfequies of Patroclus, and Acbilles; and fomewhat elder in the Theban warre, and folemn combufton of Meneceus, and Archemorus, contemporary unto fair the Eighth Judge of Ifrael. Confirmable allo among the Tro. jans, from the Funerall Pyre of Hectar, burnt before the gates of Troy, And the bo. Cala- b burning of Penibifoles the Amazoneass ber. ib.r. Queen: and long continuance of that practice, in the inward Countries of $A$ fas; - Ammia. whille as low as the Reign of Julran, we linus, Gumbrates King of Chionia a Countrey near Perfis. * Arnoldis Montanis not in $C x$. Commetar. L.L. Gvraldus. Kirkmannus.

finde that the King of cliowia c burnt the body of his $S_{0}$, and interred the afhes in a filver Urne.

The fame practice extended alfo farre Weft *, and befides Herulians, Getes, and Thracians, was in ufe with moft of the Celta, Sarmatians, Germens, Geuls, Danes, Swedes, Norwegians; not to omit fome ufe thereof among Cartbaginians and Americans: 


\section{Vrne-Buriall.}

ricans: Of greater Antiquity among the Romans then moft upinion, or Pliny feems to allow. For (befide the old Table Laws of burning ${ }^{d}$ or burying within the City, ${ }^{d}{ }_{12}$. Tabul. of making the Funerall fire with plained wood, or quenching the fire with wine.) Manlius the Cunful burne the body of his Mantius the Conf Son : Num a by lpeciall claufe of his Will, fepelito, was not burnt but buried; And R. mus neve urito. was folemnly buried,according to the defeription of Ovide.

part. I. de jure ficro. Hominem mortuum tom 2. Rogum af́ciân ne polito.

to.4. Item vigeneri Annotat. in Livium. \& Alex.ab Alex. cum Tiraquello. Rofcinus cum dempftero. - Ultima prolato fubdita flamma rogo. De Faft. lib.4. cum Car. Neapol. anapty xi.

Cornelius sylla was not the firft whofe body was burned in Rome, but of the Cornelian Family, which being indifferently, not frequently ufed before; from that time fpread, and became the prevalent practice. Not totally purfued in the highe ft runne of Cremation; For when even Crows were funerally burnt, Popsea the Wife of Nero found a peculiar grave enterment. Now as all cuftomes were founded upon fome bottome of Reafon, fo there wanted not grounds for this; according to feverall a pprehenfions of the moft rationall diffolution. Some

$$
\text { B } 3
$$

being 
being of the opinion of Thales, that water was the originall of all things, thought it moft equall to fubmit unto the principle of putrefaction, and conclude in a moift relentment. Others conceived it moft natural to end in fire, as due unto the mafter principlein the compofition, according to the doctrine of Heraclitus. And therefore heaped up large piles, more actively to waft them toward that Element, whereby they allo declined a vifible degeneration into worms, and left a lafting parcell of thcir compofition.

Some apprehended a purifying virtue in fire, refining the groffer commixture, and firing out the Ethereall particles fo deeply inmerfed in it. And fuch as by tradition or rationall conjecture held any hint of the finall pyre of all things; or that this Element at laft mult be too hard for all the reft ; might conceive moft nanaturally of the fiery diffolution. Others pretending no natural grounds, politickly declined the malice of enemies upon their buried bodies. Which confideration led sylla unto this practife; who having thus ferved the body of Marius, could not but fear a retaliation upon 


\section{Vrie-Buriall.}

his own; entertained after in the Civill wars, and revengeful cont entionsof Rome. But as many Nations einbraced, and many left it indifferent, fo others too much affected, or Atrictly declined this practice. The Imdian Bracbmans feemed too great friends unto fire, who burnt themfelves alive, and thought it the nobleft way to end their dayes in fire; according to the expreffion of the Indian, burning himfelf at Atbens, in his laft words upon the pyre unto the amazed Ipectators, Thus I make my Selfe Immortall.

But the Cbaldcans the great Idolaters of fire, abhorred the burning of their carcaffes, as a pollution of that Deity. The Perfian Magi declined it upon the like feruple, and being only follicitous about the ir bones, expored their tleth to the prey of Birds and Dogges. And the Perfees now in Isdra, which expofe their bodies unto Vultures, and endure not fo much as feretra or Beers of Wood, the proper Fuell of fire, are led on with fuch niceties. But whether the ancient Germans who burned their dead, held any fuch fear to pollute their Deity of Herthus, or

$$
\text { B } 4
$$

f And therefore the Infcription of his Tomb wis made accordingly. Nic.Damasc. 
the earth, we have no Authentick conjecure.

The Egyptians were afraid of fire, not as a Deity, but a devouring Element, mercilcny confuming their bodies, and leaving too little of them; and therefore by precious Embalments, depofiture in dry earths, or handfome inclofure in glatfes, contrived the notableft wayes of intezrall confervation. And from fuch Egyprian fcruples imbibed by Pythagoras, it may be conjectured that Numa and the Pyrhagoricall Sect firft waved the fiery foluxion.

The Scythians who fwore by winde and fword, that is, by life and death, were In farre from burning their bodies, that they diclined all interrment, and made their graves in the ayr: And the I6htbyophagi or fih-eating Nations about Egypt, affected the Sea for their grave: Thereby declining vifible corruption, and refturing the debt of their bodies. Whereas the old Heroes in Homer, dreaded nothir g more than water or drowning; probably upon the old opinion of the fiery fubftunce of the foul, only extinguifhable by that Element; And

there- 


\section{Vrne-Buriall.}

therefore the Poet emphatically implieth the totall deftruction in this kinde of death, which happened to Ajax Oileus.

The old * Balearians had a peculiar Magius mode, for they ufed great Umes and much wood, but no fire in their burials, while they bruifed the fleth and bones of the dead, crowded them into Urnes, and laid heapes of wood upon them. And the * Chinois without cremation or * Ramufun urnall interrment of their bodies, make in Navigat. ufe of trees and much burning, while they plant a Pine-tree by their grave, and burn great numbers of printed draughts of flaves and horfes over it, civilly content with their companies in effigie, which barbarous Nations exact unto reality.

Chriftians abhorred this way of oblequies, and though they ftickt not to give their bodies to be burnt in their lives, detefted that mode after death; affecting rather a depofiture than abfumption, and properly fubmitting unto the Fentence of God, to return not unto aThes but unto duft againe, conformable unto the practice of the Patriarchs, the

Siculws. 
terrment of our Saviour, of Peter, Paul, and the ancient Martyrs. And fo farre at laft declining promifcuous enterrment

Martialis with Pagans, that fome have fulfered Ecthe Bifhop. clefiaftical cenfures, for making no fcruCyprian. ple thereof.

The Mufelman beleevers will never admit this fiery refolution. For they hold a prefent trial from their black and white Angels in the grave; which they muft have made fo hollow, that they may rife upon their knees.

The Jewilh Nation, though they entertained the old way of inhumation, yet fometimes admitted this practice. For the men of $f a b e ß\}$ burnt the body of Saul. And by no prohibited practice to avoid contagion or pollution, in tiune of peftiAmos 6. lence, burnt the bodies of their friends $h$.

ro. And when they burnt not their dead bodies, yet fometimes ufed great burnings neare and about them, deducible from the expreflions concerning Feboram, Sedechias, and the fumptuous pyre of $A \int_{a}$ :

i Sueton. in And were fo little averfe from i Pagan vita. Ful. burning, that the Jews lamenting the
cef. death of $c e \int a r$ their friend, and revenger on Pompey, frequented the place where 


\section{Wrne-Buriall.}

his body was burnt for many nights together. And as they raifed noble Monuments and Maufoleums for their own $\mathrm{Na}$ tion *k, fo they were not fcrupulous in $\mathrm{e}$ recting fome for others, according to the practice of Daniel, who left that laft. ing fepulchrall pyle in $\varepsilon$ chbatana, for the Medean and Perfias Kings 1.

But even in times of fubjection and hotteft ufe, they conformed not unto the Romane practice of burning; whereby the Prophecy was fecured concerning the body of Chrift, that it thould not fee corruption, or a bone fhould not be broken; which we beleeve was alfo providentially prevented, from the Souldiers As that magnificent fepul; chral Mo. nument erected by Simon. Mach.I.J3.

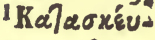

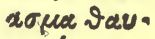

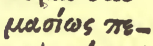
roinutrov, whereof a Jewilh Prieft had alwayes the cuftody unto fofopbus his dayes. Fof. Spear and nails that paft by the little bones both in his hands and feet : Not of ordinary contrivance, that it thould nat comupt on the Croffe, according to the Laws of Romane Crucifixion, or an hair of his head perifh, though obfervable in Jewifh cuftomes, to cut the hairs of Malefactors.

Nor in their long co-habitation with Egy ptians, crept into a cuftome of their exact embalming, wherein deeply flathing the mufcles; and taking out the 
brains and entrails, they had broken the fubject of fo entire a Refurrection, nor fully anfwered the types of Enoch, Eliah, or Jonah, which yet to prevent or reftore, was of equall facility unto that rifing power, able to break the fafciations and bands of death, to get clear out of the Cere-cloth, and an hundred pounds of oyntment, and out of the Sepulchre before the ftone was rolled from it.

But though they embraced not this practice of burning, yet entcrtained they many ceremonies agreeable unto Greeke and Romane obfequies. And he that obferveth their funerall Feafts, their Lamentations at the grave, their mufick, and weeping mourners; how they clored the eyes of their friends, how they wathed, anointed, and kiffed the dead; may eafily conclude thefe were not meere Pagan-Civilities. But whether that mournfull burthen, and treble calling out after Abfalom, had any reference unto the laft conclamation, and triple valediction, ufed by other $\mathrm{Na}$ tions, we hold but a wavering conjecture. 


\section{Urne-Bmriall.}

civiliass make fepulture but of the Law of Nations, others doe naturally found it and difcover it alfo in animals. They that are fo thick skinned as ftill to credit the ftory of the Phoenix, may fay fomething for animall burning: More Ferious conjectures finde fome examples of fepulture in Elephants, Cranes, the Sepulchrall Cells of Pifmires and pratice of Bees; which civill fociety carrieth out their dead, and hath exequies, if not interrments. 


\section{CHAP. II.}

THE Solemnities, Ceremonies, Rites
of their Cremation or enterrment, fo folemnly delivered by Authours, we thall not difparage our Reader to repeat. OnJy the laft and lafting part in their Urns, collected bones and Alhes, we cannot wholly omit, or decline that Subject, which occafion lately prefented, in fome difcovered among us.

Ina Field of old walsinghawn, not ma* ny moneths paft, were digged up between fourty and fifty Vrnes, depofited in a dry and fandy foile, not a yard deep, nor farre from one another: Not all ftrictly of one figure, but moft anfwering thefe defcribed: Some containing two pounds of bones, diftingurthable in skulls, ribs, jawes, thigh-bontes, and teeth, with frefh impreffions of their combuftion. Befides the extraneous

* In one fent me by my worthy friend. D* Thomas Witherley of Walfingham. fubftances. like peeces of fmall boxes, or combes handfomely wrought, handles of fmall braffe inftruments, brazen nippers, and in one fome kinde of opale*. 
Near the fame plot of ground, for about fix yards compaffe were digged up coals and incinerated fubftances, which begat conjecture that this was the Ufring or place of burning their bodies.or fome facrificing place unto the Marzes, which was properly below the furface of the ground, as the Are and Altars unto the gods and Heroes above it.

That thefe were the Vrnes of Romanes from the common cuftome and place where they were found, is no obfcure conjecture, not farre from a Romane Garrifon, and but five Miles from Brancuster, fet down by ancient Record under the name of Brannodunum- And where the adjoyning Towne, containing feven Parifhes, in no very different found, but Saxon Termination, ftill retains the Name of Burnham, which being an early ftation, it is not improbable the neighbour parts were filled with habinations, either of Romanes themfelves, or Britreins Romanifed, which obferved the Romonne cuftomes.

Nor is it improbable that the Romanes early poffeffed this Countrey; for though we meet not with fuch ftritt particulars 
of thefe parts, before the new Inftituti. on of Conflantine, and military charge of the Count of the Saxonfhore, and that about the Saxon Invafions, the Dalmatian Horfemen were in the Garrifon of Brancafer: Yet in the time of Claudius, $\mathrm{Ve}$ ppafsan, and severus, we finde no leffe then three Legions difperfed through the Province of Brittain. And as high as the Reign of Claudius a great overthrow was given unto the Iceni, by the Romane Lieutenant oftoriw. Not long a frer the Countrey was fo molefted, that in hope of a better ftate, Prafta agus bequeathed his Kingdome unto Nero and his Daughters 3 and Boadicea his Queen fought the laft decifive Battle with Paulinus. After which time and Conqueft of Agricole the Lieutenant of Vefpafiant, probable it is they wholly poffeffed this Countrey, ordering it into Garrifons or Habitations, beft fuitable with their fecurities. And fo fome Romanse Habitations, not improbable in thefe parts, as high as the time of Vepajan, where the Saxons after leated, in whofe thin-fill'd Mappes we yet finde the Name of Walfingham. Now if the Iceni were but Gammadims, Ancorians, 
nisss, or men that lived in an Angle wedge or Elbow of Brittain, according to the Originall Etymologie, this countrey will challenge the Emphaticall appellation, as moft properly making the Elbow or Iken of Icenia.

That Britans was notably populous is undeniable, from that expreffion of $\mathrm{C}_{e-}$ far $\mathrm{m}$. That the Romans themfelves were a Hominum early in no fmall Numbers, Seventy ivfinitarnubThoufand wich their affociats flain by titudo ef, Boadicea, affords a fure account. And gue adificia though many Roman habitations are now knowne, yet fome by old works, Rampiers, Coynes, and Urnes doe teftifie their Poffeflions. Some Urnes have ferè Galli. is confmilia. Car.de bello Gal. 1.5.

been found at Caftor, fome alfo about soushcreake, and not many years paft, no leffe then ten in a Field at Buxtonn, not near any recorded Garifon. Nor is it ftrange to finde Romane Coynes of Copper and Silver among us; of $V e j p a-$ fan, Irajan, Ad́rian, Commodus, Lsktoninus, Severus, \&ac. But the greater number of Dioclefian, Conftantine, ConJtans, Valens, with many of Viaforinus foflbumius, Tetricus, and the thirty TyIn the ground if miy worthy Friend Rob Figon Efq. whered in fome things contained were preferved hy the moft worthy Sir Williain P rants in the Reigne of Gallienus; and fon $B^{x}$.

fome 
fome as high as Adrianus have been found about Thet ford,'or Sitomagus, mentioned in the itinerary of Antoninus, as the way from Venta or Cafior unto Lon- From Ca. don ${ }^{\circ}$. But the moft frequent difcovery ford the Romanes accounted thirty two miles, and

from thence obferved not our common iroad to London, but paffed by Combretonium ad anfam, Canonium, Casaromagus, \&ec. by Bretenbam, Coggefs all, Chelmeford, Burntwood, \&c. B Moft at Cuffer by Yarmouth, fo und in a place called Eaft-bloudy-burgb furlong, belonging to Mr Thomas Wood, a perfon of civility, induftry and knowledge in this way, who hath made obfervation of remarkable things about him, and from whom we have received divers Silver and Copper Coynes. a Belonging to that Noble Gentleman, and true example of worth Sir Ralph Hare Baronet, my honoured Friend.

Befides, the Norman, Saxon and Danijh peeces of Cutbred, Canutus, William MaA peece of tilda ${ }^{a}$, and others, fom Brittilh Coynes maud the of gold have been difperfedly found; faid to be And no fmall number of filver peeces found in near b Norwicb; with a rude head upon Buckenham
Caftle with the obverfe, and an ill formed horfe on this Infri- the reverfe, with Infcriptions 1C. Duro.T. prion, Elle whether implying Iceri, Durotriges, I af
n'a elle. Bt Thoope. cia, or Trinobantes, we leave to higher conjecture. Vulgar Chronology will have Norwich Caftle as old as Fulius Ce- 
far; but his diftance from thefe parts, and its Goibick form of ftructure, abridgeth fuch Antiquity. The Britiff Coyns afford conjecture of early habitation in thefe parts, though the City of 2kerporth arofe from the ruines of Venta, and though perhaps not without fome habitation before, was enlarged, builded, and nominated by the Saxons. In what bulk or populofity it ftood in the old Eaft-angle Monarchy, tradition and hiftory are filent. Confiderable it was in the Daniff Eruptions, when Sueno burnt Thetford and Norwichc, and Vlfketel the Governour thereof, was able to make fome refiftance, and after endeavoured to burn the Danifh Navy.

How the Romannes left fo many Coynes in Countreys of their Conquefts, feems of hard refolution, except we confider how they buried them under ground, when upon barbarous invafions they were fain to defert their habitations in moft part of their Empire, and the ftrictneffe of their laws forbidding to transfer them to any other ufes; Wherein the d spartans were fingular, who to make their Copper c Brampron Abbas foernallenjis, money ufeleffe, contempered it with vi-

d Pluto in vita Lycurg. 
 \\ Hydriotapbia,}

negar. That the Brittains left any, fome wonder; fince their money was iron, and Iron rings before $C_{a} \int_{a r}$; and thore of after ftamp by permiffion, and but fmall in bulk and bigneffe; that fo few of the Saxcons remain, becaule overcome by fucceeding Conquerours upon the place, their Coynes by degrees paffed into other ftamps, and the marks of after ages.

Then the time of thefe Urnes depofited, or precife Antiquity of thefe Reliques, nothing of more uncertaintyFor fince the Lieutenant of claudius feems to have made the firtt progreffe into thefe farts, fince Boadicea was overthrown by the Forces of 2 (ero, and Agricola put a full end to thefe Conquefts; it is not probable the Countrey was fully garrifon'd or planted before; and therefore however thefe Urnes might be of later date, not likely of higher Antiquity.

And thefucceeding Emperours defift. ed not from their Conqueits in thefe and other parts ; as teftified by hiftory and medall infeription yet extant. The Province of Brittain in fo divided a diftance from Rome, beholding the faces 


\section{Vrne-Buriall.}

many Imperiall perfons, and in large account no fewer then CaSar, Claudius, Britannisus, Veßpafian, Titws, Adrian, severus; Commodus, Get a, and Caracalla.

A great obfcurity herein, becaufe no medall or Emperours Coyne enclofed, which might denote the date of their enrerrments. obfervable in many Urnes, stowes Surand found in thofe of spittle Fields by vey of LonLondon, which contained the Coynes of don.

Clandius, Vefpafran, Commodus, Antoninus, attended with Lacrymatories, Lamps, Bottles of Liquor, and other appurtenances of affectionate fuperftition, which in thefe rurall interrements were wanting.

Some uncertainty there is from the period or term of burning, or the cellation of that practife. Macrobius affirmeth it was difufed in his dayes, But moft agree, though without authestick record, that it ceafed with the Antonini. Moft fafely to be underftood after the Reigne of thole Emperours, which affumed the name of Antoninus, extending unto Heliogabalus. Not ftrictly after cuarcas; For about fifty years later we finde the magnificent burning, and con-

$$
C_{3} \text { fecration }
$$


fecration of Severus; and if we fo fix this period or ceffation, thefe Urnes will challenge above thirteen bundred years.

But whether this practife was onely then left by Emperours and great perfons, or generally about Rome, and not in other Provinces, we hold no authentick account. For after Tertullias, in the dayes of Minucius it was obviounly objected upon Chrittians, that they condem- Execrantur ned the practife of burning e. And we rogos, \&o

damnant ig. mixm Sepulsuram. Min. in $\mathrm{OA}$. S Sidon. A. pollinario. finde a paffage in sidonins $\mathrm{f}$, which afferteth that practife in France unto 2 lower account. And perhaps not fully difufed till Chriftianity fully eftablifhed, which gave the finall extinction to thefe fepulchrall Bonefires.

Whether they were the bones of men or women or children, no authentick decifion from ancient cuftome in diftinct places of buriall. Although not improbably conjectured, that the double Sepulture or burying place of Abrabasm, had in it fuch intenfion. But from exi. lity of bones, thinneffe of skulls, fmallneffe of teeth, ribbes, and thigh-bones; not improbable that many thereof were perfons of minor age, or women. Confirmable 


\section{Vrne-Buriall.}

firmable alfo from things contained in them: In moft were found fubftances refembling Combes, Plates like Boxes, faftened with Iron pins, and handfomely overwrought like the necks or Bridges of Muficall Inftruments, long brafle plates overwrought like the handles of neat implements, brazen nippers to pull away hair, and in one a kinde of opale yer maintaining a blewifh colour.

Now that they accuftomed to burn or bury with them, things wherein they excelled, delighted, or which were dear unto them, either as farewells unto all pleafure, or vain apprehenfion that they might ufe them in the other world, is teftified by all Antiquity. Obfervable from the Gemme or Berill Ring upon the finger of Cynthia, the Miftreffe of Propertius, when after her Funerall Pyre her Ghoft appeared unto him. And notably illuftrated from the Contents of that Romane Urne preferved by Cardinall Farnefe $\mathrm{g}$, wherein befides great 8 Vigeneri number of Gemmes with heads of Gods Annor, in 4. and Goddeffes, were found an Ape of Liv. Azath, a Grafhopper, an Elephant of Ambre, a Cryftall Ball, three glaffes,

$$
\mathrm{C}_{4}
$$

two 


\section{Hydriotapbia,}

two Spoones, and fix Nuts of Cryftall. - chifset in And beyond the content of Urnes, in Anaft. Childer. the Monument of childerick the firft $h$, and fourth King from Pharamond, cafually difcovered three years paft at Tour$n a y$, reftoring unto the world much gold richly adorning his Sword, two hundred Rubies, many hundred Imperial Coyns, three hundred golden Bees, the bones and horfelhoe of his horfe enterred with him, according to the barbarous magnificence of thofe dayes in their fepulchral Oblequies. Although if wre fteer by the conjecture of many and Septuagint expreffion; fome trace thereof may be found even with the ancient Hebrews, not only from the Sepulcrall treafure of David, but the circumcifion knives which gofuab allo buried.

Some men confidering the contents of there Vrnes, lafting peeces and toyes incluaded in them, and the cuftome of burning with many other Nations, might fomewhat doubt whether all Vrnes found among us, were properly Romane Reliques, or fome not belonging unto our Brittifh, Saxon, or Danifh Forefathers.

In sbe form of Burial! among the ancicue 


\section{Vrne.Buriall.}

cient Brittains, the large Dilcourfes of

Cafar, Tacitus, and Strabo are filent: For the difcovery whereof, with other particulars, we much deplore the loffe of that Letter which Cicero expected or received from his Brother 2uintus, as a refolution of Brittifl cuftomes; or the account which might have been made by Scribowins Largus the Phyfician, accompanying the Emperour Claudius, who might have alfo difcovered that frugall Bit i of i Dionis-exthe Old Brittains, which in the bigneffe cerpstaper of a Bean could fatisfie their thirft and $\begin{gathered}\text { Xnphilim } \\ \text { in Severo. }\end{gathered}$ hunger.

But that the Druids and ruling Priefts ufed to burn and bury, is expreffed by Pomponius; That Bellinus the Brother of Brenwus, and King of Brittains was burnt, is acknowledged by Polydorus, as alfo by Amsandus Zierexenfos in Hiftoria, and Pineda in his Vniverja bistoria. Spanifh. That they held that practife in Gallia, Cafar exprefly delivereth. Whether the Brittains (probably defcended from them, of like Religion, Language and Manners) did not fometimes make ufe of burning; or whether at leaft fuch as were after civilized unto the Romane life 
and manners, conformed not unto this practife, we bave no hiftoricall affertion or deniall. But fince from the account of Tacitas the Romanes early wrought fo much civility upon the Brittifh ftock, that they brought them to build Temples, to wear the Gowne, and ftudy the Romane Laws and language, that they conformed alfo unto their religious rites and cuftomes in burials, feems no im. probable conjecture.

That burning the dead was ufed in Sarmatia, is affirmed by Gaguinus, that the Sueons and Gotblanders ufed to burne their Princes and great perfons, is delivered by Saxo and Olans; that this was the old Germane practife, is allo afferted by Tacitus. And though we are bare in hiftoricall particulars of fuch obfequies in this Inland, or that the Saxcons, Futes, and Angles burnt their dead, yet came they from parts where 'twas of ancient practife; the Germanes ufing it, from whom they were defcended. And even in Futland and slefroick in Anolin Cymbrica, Vrnes with bones were found not Roifoldi many years before us. Brendetiides
Ild tyde. 


\section{Urne-Buriall.}

have salfed an IFra or point of compute from their Cuftome of burning their dead: Some deriving it from Vnguinus, fome from Frotbo the great; who ordained by Law, that Princes and Chief Commanders fhould be committed unto the fire, though the common fort had the common grave enterrment. So Starketterus that old Herce was burnt, and Ringo royally burnt the body of Harald the King flain by him.

What time this cuftome generally expired in that Nation, we difcern no affured period; whether it ceafed before Chriftianity, or upon their Converfion, by Aus garius the Gaul in the time of $\mathrm{Lu}$ dovicus Pius the Sonne of Charles the great, according to good computes; or whether it might not be ufed by fome perfons, while for a hundred and eighty years Paganifme and Chriftianity were promifcuoufly embraced among them, there is no affured conclufion. About which times the Danes were bufie in Engand, and particularly in fefted this Counrey: Where many Caftles and ftrong rolds, were built by them, or againft hem, and great number of names and 
Families ftill derived from theri:o' But fince this cuftome was probably difufed before their Invafion or Conqueft, and the Romanes confeffedly practifed the fame, fince their polfeffion of this Ifland, the moft affured account will fall upon the Romanes, or Brittains Romanized.

However certain it is, that Vrnes conceived of no Romane Originall, are often digged up both in Norway, and Demmark. handfomely defcribed, and graphically reprefented by the Learned Phyfician olaiWor- Wormius', And in fome parts of Denmii monnmenta o Antiquitat.

Dan.

- Adolpbus Cyprius in Annal. Sles. soic. urnis adeo abundabat collis; \& ic.

- In Ox. fordfhire; Cambden. mark in no ordinary number, as ftands delivered by Authours exactly defcribing thofe Countreys $m$. And they contained not only bones, but many other fubftances in them, as Knives, peeces of Iron, Braffe and Wood, and one of 2 Corwaye a braffe guilded Jewes-harp.

Nor were they confuled or careleffe in difpnfing the nobleft fort, while they placed large ftones in circle about the Vrnes, or bodies which they interred: Somewhat anfwerable unto the Monument of Rollicich ftones in Exglasd $n$, or fepulcrall Monument probaby erected by Rollo, who afrer conquered Normandy. 


\section{Vrne-Buriall.}

Where 'tis not improbable fomewhat might be difcovered. Mean while to what Nation or perfon belonged that large Vrne found at Afbburie ${ }^{\circ}$, contain- $\triangle$ Inche. ing mighty bones, and a Buckler; What fhire, Tmithofe large Vrnes found at little Maßing - nus de rebus . Albionicis. bam P, or why the Anglefea Urnes are p In Nor. placed with their mouths downward, folk, Holremains yet undifcovered. lingjbead. 


\section{CHAP. III.}

of a righteous ; vlyes in Hecubab

PLayftered and whited Sepulchres, 1 were anciently affected in cadaverous, and corruptive Burials; And the rigid Jews were wont to garnifh the Sepulchres Mat.23. Of the a righteous; Eurspides. cared not how meanly he lived, fo he might finde a noble Tomb after death. Great Princes affected great Monuments And the fair and larger Urnes contained no vulgar afhes, which makes that difparity in thole which time difcovereth among us, The prefent Urnes were not of one capacity, the largeft containing above a gallon, Some not much above half that meafure; nor all of one figure, wherein there is no ftriat conformity, in the fame or different Countreys; Obfervable from thofe reprefented by $\mathrm{Ca} / \mathrm{a}$ lius, Bofso, and others, though all found in Italy. While many have handles, ears, and long necks, but moft imitate a circular figure, in a fphericall and round 
compofure; whether from any myftery, beft duration or capacity, were but a conjecture. But the common form with necks was a proper figure, making our Iaft bed like our firft; nor much unlike the Urnes of our Nativity, while

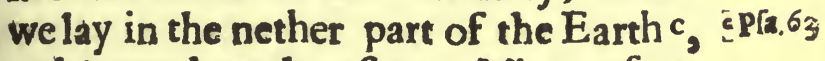
and inward vault of our Microcofme. Many Urnes are red, thefe but of a black colour, fomewhat fmooth, and dally founding, which begat fome doubt, whether they were burnt, or only baked in Oven or Sunne: According to the ancient way, in many bricks, tiles, pots, and teftaceous works; and as the word testa is properly to be taken, when occurring without addition: And chiefly intended by Pliny, when he commendeth bricks and tiles of two years old, and to make them in the fpring. Nor only thefe concealed peeces, but the open magnificence of Antiquity, ran much in the Artifice of Clay. Hereof the houfe of Marfolus was built, thus old Fupiter ftood in the Capitoll, and the Statua of Hercules made in the Reign of Tarqwinias Prijcus, was extant in Plinies dayes. And fuch 
fuch as declined burning or Funerall Urnes, affected Coffins of Clay, according to the mode of Pythagoras, a way preferred by Varro. But the Ipirit of great ones was above thefe circumfcriptions, affecting copper, filver, gold, and Porphyrie Urnes, wherein Severus lay, after a ferious view and fentence on that which thould contain himd. Some of thefe Urnes were thought to have been

dXcopnosis $\operatorname{Tov} \alpha^{x} v \vartheta \rho \omega^{\circ}$ $\pi 0 \%$, ov $v$

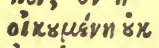
ix ćpnozy. Dion. filvered over, from fparklings in feveral pots, with fmall Tinfell parcels; uncertain whether from the earth, or the firft mixture in them.

A mong thefe Urnes we could obtain no good account of their coverings; Only one feemed arched over with fome kinde of hrickwork. Of thofe found at Buxton fome were covered with Hints, fome in other parts with tiles, thofe at $Y_{\text {armouth }}$ Cafter, were clofed with Romane bricks. And fome have proper earthen covers adapted and fitted to them. But in the Homericali U rne of Patroclus, whatever was the folid Tegument, we finde the immediate covering to be a purple peece of filk: And fuch as had no copeece 


\section{Vrre Buriall.}

vers might have the earth clofely preffed into them, after which difpofure were probably fome of there, wherein we found the bones and athes half mortered unto the fand and fides of the Urne; and fome long rocts of Quich, or Dogs-grafs wreathed about the bones.

No Lamps, included L quors, Lachrymatories, or Tear-bottles attended thefe rurall Urnes, either as facred unto the Manes, or paffionate expreffions of their furviving friends. While with rich tlames, and hired tears they folemnized their Oblequies, and in the molt lamented Monuments made one part of their Infcriptions c. Some finde fepulchrall Veffels containing liquors, which time hath incraffated into gellies. For befide thefe Lachrymatories, notable Lamps, with Veffels of Oyles and Aromaticall Liquors attended noble Offuaries. And fome yet retaining a * Vinofity and * Laxius. Ipirit in them, which if any have tafted they have farre exceeded the Palats of Antiquity.Liquors not to be computed by years of annuall Magiftrates, but by great conjunctions and the fatall periods suere. 
${ }^{\text {A Abour five Kingdomes }} \mathrm{f}$. The draughts of Confuhundred years. Plato. 8 Vinum 0 . pimis ian:m anroo:um centum. Petron. lary date, were but crude unto thefe, and Opimian $\mathrm{g}$ Wine but in the muft unto them.

In fundry Graves and Sepulchres, we meet with Rings, Coynes, and Chalices; Ancient frugality was fo fevere, that they allowed no gold to attend the Corps, but only that which ferved to -12. Tabul. 1.xi. de $y_{u}$ re facro. Nieve aurum addiro, aft quoi curo denies vinsti e i unt, imsumallo Sipelive do urein, je fraine effo. faften their teeth $h$. Whether the Opaline ftone in this Urne were burnt upon the finger of the dead, or caft into the fire by fome affectionate friend, it will confift with either cuftome. But other incinerable fubftances were found fo frefh, that they could feel no findge from fire. Thefe upon view were judged to be wood, but finking in water and tried by the fire, we found them to be bone or Ivory. In their hardneffe and yellow colour they moft refembled Box, which in old expreffions found the Epii Plin l. .xvi. thete ${ }^{i}$ of Eternall, and perhaps in fuch In: $\operatorname{si} \xi u^{\prime} \lambda \alpha$

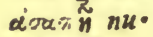
merai Theo. thrafius. confervatories might have paffed uncorrupted.

That Bay-leaves were found green in s suivus. the Tomb of S.Humbert $k$, after an hundred and fifty years, was looked upon 
as miraculous, Remarkable it was unto oid Spectators, that the Cypreffe of the Temple of Diana, lafted fo many hundred years: The wood of the Ark and Olive Rod of Aaron were older at the Captivity. But the Cyprefle of the Ark of Noab, was the greateft vegerable Anciquity, if fo/ephus were not deceived, by fome fragments of it in his dayes. To omit the Moore-logs, and Firre-trees found under-ground in many parts of England; the undated ruines of windes, flouds or earthquakes; and which in Flanders ftill thew from what quarter they fell, as generally lying in a NorthEaft pofition?.

But though we found not thefe peeces to be Wood, according to firft apprehenfion, yet we miffed not altogether of fome woody fubftance; For the bones were not fo clearly pickt, but fome coals were found amongtt them; A way to make wood perpetuall, and a fit affociat for metall, whereon was laid the foundation of the great $\varepsilon p h e f z a n$ Temple, and which were made the lafting tefts of old boundries and Landmarks; Whileft we look on thefe, we admire lofeopio. 


\section{$3^{6}$ \\ Hydriotapbia,}

not Obfervations of Coals found freth, bof Berin- after four hundred years $\mathrm{m}$. In a long guccio nella pyrosecbnia. at Elmaham, deferted habitation ${ }^{n}$, even Egge-lhels have been found frefh, not tending to corruption.

In the Monument of King Cbilderick, the Iron Reliques were found all rufty and crumbling into peecees. But our little Iron pins which faftened the Ivory works, held well together, and loft not their Magneticall quality, though wanting a tenacious moifture for the firmer union of parts, although it be hardly drawn into fufion, yet that metall foon fubmitteth unto reft and diffolution. In the brazen peeces we admired not the duration but the freedome from ruft, and ill favour; upon the hardeft attrition, but now expofed unto the piercing Atomes of ayre; in the fpace of a few moneths, they begin to fot and betray their green entrals. We conceive not thefe Urnes to have defcended thus naked as they appear, or to have entred their graves without the old habit of flowers. The Urne of Pbilopamen was fo laden with flowers and ribbons, that it afforded no fight of it felf. The rigid $L y$ cor- 
$g$ us allowed Olive and Myrtle. The Athenians might fairly except againtt the practife of Demecritus to be buried up in honey; as fearing to embezzle a great commodity of their Countrey, and the beft of that kinde in Europe. But Plaso feemed too frugally politick, who allowed no larger Monument then would contain for Heroick Verfes, and defigued the moft barren ground for fepulture: Though we cannot commend the goodneffe of that fepulchrall ground, which was fet at no higher rate thea the mean falary of 7 mas. Though the earth had confounded the athes of thefe Offuaries, yet the bones were fo fmartly burnt, that fome thin plates of braffe were found half melted among them : wheraby we apprehend they were not of the meaneft carcaftes, perfunctorily $f$ red as fometimes in military, and commonly in peftilence, burnings; or afier the manner of abject corps, hudled forth and carelefly burnt, without the Efquiline Port at Rome; which was an affront continued upon Tiberius, while they but half burnt his body *, and in the Amphitheatre, according to the cu-

D 3 ftome

* Sueton.in vita Trb. 6 in Ampio. thearro fes minftulian: chem, nor. confonto 


\section{$3^{8} \quad$ Hydriotapbia,}

ftome in notable Malefactore; whereas 2Nero feemed nos fo much to feare his death, as that his head fhould be cut off, and his body not burnt entire.

Some finding many fragments of fculs in thefe Urnes, fufpected a mixture of bones; In none we fearched was there caufe of fuch conjecture, though fometimes they declined not that practife; bSutton. in The afhes of b Domitian were mingled

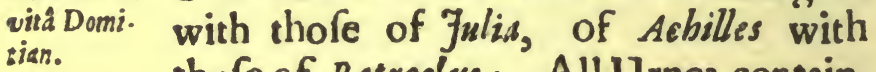

thufe of Patroclus : All Urnes contained not fingle alhes; Without confufed burnings they affectionately compounded their bones; paffionately endeavouring to continue their living Unions. And when diftance of death denicd fuch conjunctions, unfatisfied affections, conceived fome fatisfaction to be $n$-ighbours in the grave, to lye Urne by Uirne, and touch but in their names. And many were fo curious to continue their living relations, that they contrived large, and

\& S. the family Ulrnes, wherein the Alhes of their

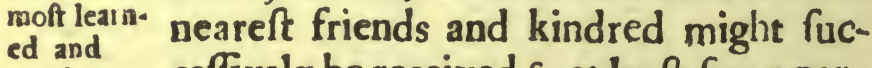
swo: thy M× M.CaSuben upon Linto vimes. ceffively be received c, at leaft fome parcels thereof, while their collaterall memorials lay in minor veffels about them. 


\section{Vrme-Buriall.}

Antiquity held too light thoughts from Objects of mortality, while fome drew provocatives of mirth from Ana- a sic erimus tomies $\mathrm{d}$, and Juglers thewed tricks with ${ }_{\mathrm{E} \text { rgo dum }}^{\mathrm{cungi}}$, \&c. Skeletons. When Fidlers made not fo vivimus vipleafant mirth as Fencers, and men could vamus. fit with quiet ftomacks while hanging e'Avxwivn was plaied e before them, Old confide- aristrv. A barbarous

paftime at Feafts, when men ftnod upon a rolling Globe, with their necks in a Rope, and a knife in their hands, ready to cut it when the ftone was rolled away, wherein if they failed, they loft their lives to the laughter of their fpectators Aibenaus.

rations made few memento's by fculs and bones upon their monuments. In the Egyptian Obelisks and Hieroglyphicall figures it is not eafie to meet with bones. The fepulchrall Lamps fpeak nothing leffe then fepulture; and in their literall draughts prove often obfcene and antick peeces : Where we finde $D . M{ }_{0}{ }^{\mathrm{f}}$ it is obvious to meet with facrificing patera's, bus and veffels of libation, upon old fepulchrall Monuments. In the Jewilh Hypogaum 8 and fubterranean Cell ac Rome, was little obfervable befide the variety of Lamps, and frequent draughts of the holy Candleftick. In authentick draughts of Anthony and Jerome, we meet with

$$
\text { D } 4 \text { thigh- }
$$


thigh-bones and deaths heads; but the cemireriall Cels of ancient Chriftians and Martyrs, were filled with draughts of Scripture Stories; not declining the flourithes of Cypreffe, Palmes, and $\mathrm{O}$ live; and the myfticall Figures of Peacocks, Doves and Cocks. But iterately affecting the pourtraits of Enoch, Lazarus, Fonas, and the Vifion of Ezechiel, as hopefull draughts, and hinting imagery of the Refurrection; which is the life of the grave, and Tweetens our habitations in the Land of Moles and Pifmires.

Gentile Infcriptions precifely delivered the extent of mens lives, feldome the manner of their deaths, which hiftory it felf fo often leaves obfcure in the records of memorable perfons. There is fcarce any Philofopher but dies twice or thrice in Laertius; Nor almoft any life without two or three deaths in Plutarch; which makes the tragicall ends of noble per. fons more favourably refented by compaffionate Readers, who finde fome relief in the Election of fuch differences.

The certainty of death is attended with uncertainties, in time, manner, $\checkmark$

places. 


\section{Urne-Buriall.}

places. The variety of Monuments hath often obfcured true graves : and Cersotaphs confounded Sepulchres. For befide their reall Tombs, many have found honorary and empty Sepulchres. The variety of Homers Monuments made him of various Countreys. Euripides had his "Paufan, in Tomb in Africa, but his fepulture in Mz- Aticis * cedonis. And severus i found his real Sepulchre in Korse, but his empty grave in Gallie.

He that lay in a golden Urne ${ }^{k}$ eminently above the Earth, was not like to iLamprid. in vit. Alexo= and. Severi. Trajanus. Dion. finde the quiet of there bones. Many of thefe Urnes were broke by a vulgar difcoverer in hope of inclofed treafure. The afhes of usarcellus ${ }^{1}$ were loft above ground, upon the like account. Where 1 Plut. in profit hath prompted, no age hath wanted fuch miners. For which the mott barbarous Expilators found the moft civill Rhetorick. Gold once out of the earth is no more due unto it; What was unrealonably committed to the ground is reafonably refumed from it : Let Monuments aud rich Fabricks, not Riches adorn mens athes. The commerce of the living is not to be trrnsfer-

The Com. miffion of rhe Gothiffo King 1beodoric for finding out fepulchrall treafure. Caffodor. Var.1.4。 red 
red unto the dead : It is not injuftice to take that which none complains to lofe, and no man is wronged where no man is poffeffor.

What virtue yer. Aleeps in this terra damnats and aged cinders, were petty magick to experiment ; Thefe crumbling reliques and long-fired particles fua Briamis perannate fuch expectations : Bones, bodie sam ationitécedebrat tantis hairs, nails, and teeth of the dead, were the treafures of old Sorcerers. In vain ceremoniis, ut dediff? Perfis videri pofit. Plin.1.29. we revive fuch practices; Prefent fuperftition too vifibly perpetuates the folly of our Fore-fathers, wherein unto old Oblervation this Ifland was fo compleat, that it might have inftructed Perfia.

Plato's hiftorian of the other world, lies twelve dayes incorrupred, while his foul was viewing the large ftations of the dead. How to keep the corps feven dayes from corruption by anointing and walhing, without exenteration, were an hazardable peece of art, in our choifeft practife. How they made diftinct feparation of bones and alhes from fiery admixture, hath found no hiftoricall folution. Though they feemed to make a diftinct 


\section{Vrne-Buriall.}

diftinct collection, and overlooked not Pyrrbus his toe. Some provifion they might make by fictile Veffels, Coverings, Tiles, or flat ftones, upon and about the body. And in the fame Field, not farre from thefe Urnes, many ftones were found under ground, as alfo by carefull feparation of extraneous matter, compofing and raking up the burnt bones with forks, obfervable in that notable lump of Galuarnes Martianus b, who had the fight of the Vas V?frinum, or veffell wherein they burnt the dead, found in the Eqquiline Field at Rome, might have afforded clearer folution. But their infatisfaction herein begat that remarkable invention in the Funerall Pyres of fome Princes, by incombuftible fheets made with a texture of Asbefos, incremable flax, or Salamanders wool, which preferved their bones and afhes $\mathrm{c}$ incommixed.

How the bulk of a man thould fink into fo few pounds of bones and athes, may feem ftrange unto any who confiders not its conftitution, and how flender a maffe will remain upon an open and urging fire of the carnall compofition.

b Topyerapbia Roma ex Martiaano. Erat or vass uffrinum appellatum quod in eo cadevera comburerentur. Cap.de Campo Ef. quilino. 'To be feen in $\mathrm{Li}$. cet. de reconditis veterum lucervis. 
on. Even bones themfelves reduced in to alhes, do abate a notable proportion And confifting much of a volatile falt, when that is fired out, make a light kind of cinders. Although their bulk be difproportionable to their weight, when the heavy principle of Salt is fired out, and the Earth almoft only remaineth; Obfervable in fallow, which makes more Afhes then Oake; and difcovers the common fraud of felling Afhes by meafure, and not by ponderation.

- Old bones according to Lyferus. Thofe of young perfons not tali nor fat according toicolumbus b In vite. Gracc. -Tbucydides. d Laxrent. Valla.

- Excutósa-

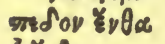
iี้

Some bones make beft Skeletonsa, fome bodies quick and fpeedieft antes : Who would expect a quick flame from Hydropicall Heraclitus? The poyfoned Souldier when his Belly brake, put out two pyres in Pluzarch b. But in the plague of Atbens c, one private pyre ferved two or three Intruders; and the Saracens burnt in large beaps, by the King of Caftiled, Thewed how little Fuell fufficeth. Though the Funerall pyre of Patrochis took up an hundred foot $e$, a peece of an old boat burnt Pompey; And if the burthen of $1 \int a a c$ were fufficient for an holocauft, a man may carry his owne pyre. 


\section{Urne-Buriall.}

From animals are drawn good burning lights, and good medicines $f$ againft burning; Though the feminall humour feems of a contrary nature to fire, yet the body compleated proves a combuftible lump, wherein fire findes flame even from bones, and fome fuell almoft from all parts. Though the \& Metropolis of humidity feems leaft difpofed unto tThe brain. Hippocrates. it, which might render the foulls of thefe Urnes leffe burned then other bones. But all flies or finks before fire almoft in all bodies: When the common ligament is diffolved, the attenuable parts afcend, the reft fubfide in coal, cals or afhes.

To burn the bones of the King of $\mathrm{d} E$ - ¿Amos 2.r. dom for Lyme, feems no irrationall ferity; But to drink of the afhes of dead relations $\mathrm{e}$, a paffionate prodigality. $\mathrm{He}$ that hath the alhes of his friend, hath an everlafting treafure: where fire taketh

Speran. A.lb, Ovot?

leave, corruption flowly enters ; In bones well burnt, fire makes a wall againft it felf; experimented in copels, and refts of metals, which confift of fuch ngredients. What the Sun compoundeth, fire analyfeth, not tranfmuteth.

- As Arte mifia of her Husband Maw: folus. 
$46 \quad$ Hydriotapbia,

That devouring agent leaves almoft all. wayes a morfell for the Earth, whereof all things are but a colonie; and which, if time permits, the mother Element will have in their primitive malfe again.

He that looks for Urnes and old fepulchrall reliques, muft not feek them in the ruines of Temples; where no Religion anciently placed them. Thefe were found in a Field, according to ancient cuftome, in noble or private buriall; the old practife of the Canaanites, the Family of Abrabam, and the burying place of fofwa, in the borders of his polfeffions; and allo agreeable unto Roman practice to bury by high-wayes, whereby their Monuments were under eye: Memorials of themfelves, and memento's of mortality into living paffengers; whom the Epitaphs of great ones were fain to beg to ftay and look upon them. A language though fometimes ufed, not a sife via- fo proper in Church-Infcriptions a. The ter.

fenfible Rhetorick of the dead, to exemplarity of good life, firft admitted the bones of pious men, and Martyrs within Church-wals; which in fucceeding ages

crepe 


\section{Vrne-Buriall.}

crept into promifcuous practife. While conftantine was peculiarly favoured to be admitted unto the Church Porch;and the firft thus buried in England was in the dayes of Cuthred.

Chriftians difpute how their bodies frould lye in the grave. In urnall en-

terrment they clearly efcaped this Controverfie: Though we decline the Religious confideration, yet in cemiteriall and narrower burying places, to avoid confufion and croffe pofition, a certain pofture were to be admitted; Which even Pagan civility obferved, The Per/zans lay North and South, The Megarians and Pbrenicians placed their heads to the Eaft: The Atbenians, fome think, towards the Weft, which Chriftians ftill retain. And Beds will have it to be the pofture of our Saviour. That he was crucified with his face towards the Weft, vre will not contend with tradition and probable account; But we applaud not the hand of the Painter, in exalting his Crofle fo high above thofe on either fide; fince hereof we finde no authentick account in hiftory, and even the croffes found by Helena pretend no fuch 
diftinction from longitude or dimenfron.

To be knav'd out of our graves, to have our fculs made drinking-bowls, and our bones turned into Pipes, to delight and fport our Enemies, are Tragicall a. bominations, efcaped in burning $\mathrm{Bu}$. rials.

Urnall enterrments, and burnt Reliques lye not in fear of worms, or to be an heritage for Serpents; In carnall fepulture, corruptions feem peculiar unto parts, and fome fpeak of fnakes out of the fpinall marrow. But while we fuppofe common wormes in graves, 'tis not cafie to finde any there; few in Churchyards above a foor deep, fewer or none in Churches, though in frefh decayed bodies. Teeth, bones, and hair, give the moft lafting defiance to corruption. In au Hydropicall body ten years buried in a Church-yard, we met with a fat concretion, where the nitre of the Earth, and the falt and lixivious liquor of the body, had coagulated large lumps of fat, into the confiftence of the hardeft caftle-foap; whereof part remaineth with us. After a battle with the Perfrans 


\section{Vrne Euriall.}

fruss the Romans Corps decayed in few dayes, while the Perfata bodies remained dry and uncorrupeed. Bodies in the fame ground do not uniformly diffolve, nor bones equally moulder; whereof in the opprobrious difeafe we expect no long duration. The body of the Marqueffe of Dorfet feemed found and handfomely cereclothed, that after feventy eight years was found uncoirupted c. Common Tombs preferve not beyond powder: A firmer confiftence and compage of parts might be expected from $A$ refaction, deep buriall or charcoal. The greateft Antiquities of mortall bodies may remain in patrified bones, whereof, shough we take not in the pillar of Lots wife, or Metamorphofis of Ortelias d, fome may be older then Pyramids, in the putrified Reliques of the generall inundation. When Alexander opened the Tomb of cyrss, the remaining bones difcovered his proportion, whereof urnall fragments afford but a bad conjeCure, and have this difadvantage of

c Of Thoma Marquefie of Dorfets, whore body being buried 1530. was 1608 up on the cutting 0 . pen of the Cerecleth found perfect and nothing corrupted, the flefh not hardened. but. in colour, proportion, and foltenefíc like an ordinary corps newly to be interred. Burtons defcript, of I eicefferffire. I In bis Map of $\mathbb{R} u$ Jia. 


\section{0 \\ Hydriotapbia,}

grave cnterrments, that they leave usignorant of moft perfonall difcoveries. For fince bones afford not only rectitude and frability, but figure unto the body; It is no impoffible Phyfiog. nomy to conjecture at flefhy appendencies; and after what thape the mufcles and carnous parts might hang in their full confiftences. A full rpread Cariola thews a well-thaped horfe behinde, handfome formed fculls, give fome analogie of thefhy refemblance. A criticall view of bones makes a good diftinction of fexes. Even colour is - not beyond conjecture; fince it is hard to be deceived in the diftinction of 2 - The Poet gro's fculls. " Dantes Characters are Dante in his to be found in fculls as. well as faces. view of Purgatory, found gluttons Io $_{0}$ ineagre, and exte. Hercules is not onely known by his foot. Other parts make out their comproportions, and inferences upon whnle or parts. And fince the dimenfions of the muated, that headmeafure the whole body, and the be concei-

red them to have been in the Siege of $F_{\text {erufalem, and that it was cafie }}$ to have difcovered Homo or Omo in their faces: M being made by the two lines of their cheeks, archlng over the Eye brows to the nofe, and their funk eyes making 00 which makes up Omo. Parean l'occbiaie anella fenza gemme cbe nel vifo de gli bucment legge buomo Ben' hauria quinu conofizuso $l$ ermune. 


\section{Vrne-Buriall.}

figure thereof gives conjecture of the principall faculties; Phyfiognomy outlives our felves, and ends not in our graves.

Severe contemplators obferving thefe lafting reliques, may think them good monuments of perfons paft, little advantage to future beings. And confidering that power which fubdueth all things unto it felf, that can refume the fcattered Atomes, or identifie out of any thing, conceive it fupertluous to expect a refurrection our of Reliques. But the foul fubfifting, other matter clothed with due accidents, may falve the individuality: Yet the Saints we obferve arofe from graves and monuments, about the holy City. Some think the ancient. Patriarchs fo earneftly defired to lay their bones in Canaan, as hoping to make a part of that Refurrection, and though thirty miles from Mount Calvary, at leaft to lie in that Region, which thould produce the firt-fruits of the dead. And if according to learned conjecture, the bodies of men thall rife where their greateft Reliques remain, many are not like to erre in the Topography of their Refurrecti- 
on, though their bones or bodies be after tranlated by Angels into the field of $E$ zecbiels vifion, or as fome will order it, into the Valley of Judgement, or Jebofaphat. 


\section{CHAP. IV.}

CHriftians have handfomely gloffed the deformity of death, by careful confideration of the body, and civil rites which take of brutall terminations. And though they conceived all reparable by a refurrection, caft not off all care of enterrment. And fince the afthes of Sacrifices burnt upon the Altar of God, were carefully carried out by the Priefts, and depofed in a clean field; fince they acknowledged their bodies to be the lodging of Chrift, and temples of the holy Ghoft, they devolved not all upon the fufficiency of foul exiftence; and therefore with long fervices and full folemnities concluded their laft Exequies, wherein a to all diftinctions the Greek devotion feems moft pathetically cerremonious.

Chriftian invention hath chiefly driven at Rites, which Speak hopes of an-

Rituale Gracumiopera 7.Goar in officio exsquiarum. E 3 other 
other life, and hints of a Relurrection. And if the ancient Gentiles held not the immortality of their better part, and fome fubfiftence after death ; in feverall rites, cuftomes, actions and expreffione, they contradicted their own opinions: wherein Democritus went high, even tc. the thought of a refurrection $b$, as fcofisimilis fingly recorded by Pliny. What can be promifya Democrito vanitas, qui non revixit appe. Qua, malum, iffe dimentia esi?; iterari vitam morte. Plin 1 . 7. c. 55. "Kair $\tau \alpha^{\prime} x^{\alpha}$ Stex yoins

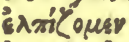
is $\cos \cos ^{2} \lambda$ -

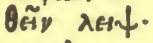
av itros. Xoúprov. of deincepsi Cedit enim retro de zerrá quod fuit ante more expreffe than the expreffion of Phocyllides c? Or who would expect from Lucretius d a fentence of Ecclefsaftes? Before Plato could fpeak, the foul had wings in Homer, which fell not, but flew out of the body into the manfions of the dead; who allo obferved that handfome diftinction of Demas and soma, for the body conjoyned to the foul and body feparated from it. Lucion fpoke much truth in jeft, when he faid, that part of Hercules which proceeded from Alchmena perifhed, that from fupiter remained immortall. Thus c socrates was content that his friends fhould bury his bo$\mathrm{dy}$, fo they would not think they buriIn tirram, \&ec. Lucrer. e Plato in Phed. 


\section{Urme-Buriall.}

ed socrutes, and regarding only his immortall part, was indifferent to be burnt or buried. From fuch Confiderations Diogenes might contemn Sepulture. And being fatisfied that the foul could oot perifh, grow careleffe of corporall enterrment.The Stricks who thought the fouls of wife men had their habitation about the moon, might make flight account of fubterraneous depofition; whereas the ythagorians and tranfcorporating Phiofophers, who were to be often burid, held great care of their enterrment. and the Platonicks rejected not a due are of the grave, though they put their thes to unreafonable expeatations, in heir tedious term of return and long fet evolution.

Men have loft their realon in nothing - much as their religion, wherein ftones nd clouts make Martyrs; and fince the eligion of one feems madneffe unto anther, to afford an account or rationall if old Rites, requires no rigid Reader; That they kindled the pyre averny, ir turning their face from it, was an rand fome Symbole of unwilling minitration; That they wafhed their bones 
with wine and milk, that the mother wrapt them in Linnen, and dryed them in her bofome, the firf foltering part, and place of their nourifhment; That they opened their eyes towards heaven, before they kindled the fire, as the place of their hopes or originall, were no improper Ceremonies. Their laft vale-

SVale, vale, nos te ordi. quo natura permittet Segremur.

diction $\mathrm{f}$ thrice uttered by the attendants was alfo very folemn, and fomewhat anfwered by Chriftians, who thought it too little, if they threw not the earth thrice upon the enterred body. That in ftrewing their Tombs the Romans affected the Rofe, the Greeks Amar anthws and myrtle; that the Funerall pyre confifted of fweet fuell, Cypreffe, Firre, Larix, Yewe, and Trees perpetually verdant, lay filent expreffions of their furviving hopes: Wherein Chriftians which deck their Coffins with Bays have found a more elegant Embleme. For that he feeming dead, will reftore it felf from the root, and its dry and exuccous leaves refume their verdure again : which if we miftake not, we have alfo obferved in fures. Whether the planting of yewe in Churchyards, hold not its originall

from 


\section{Urne-Buriall.}

from ancient Funerall rites, or as an Embleme of Refurrection from its perpetual verdure, may alfo admit conjecure.

They made ufe of Mufick to excite or quiet the affections of their friends, according to different harmonies. But the fecret and fymbolicall hint was the harmonical nature of the foul; which delivered from the body, went again to enjoy the primitive harmony of heaven, from whence it firft defcended; which acsoxding to its progreffe traced by antiquity, came down by Cancer, and afeended by Capricormus.

They burnt not children before their eeth appeared, as apprehending their bodies too tender a morfell for fire, and that their griftly bones would fearce leave feparable reliques after the pyrall combuftion. That they kindled not fire in their houfes for fome dayes after, was a ftrict memoriall of the late afflicting fire. And mourning without hope, hey had an happy fraud againft excefive lamentation, by a common opinion that deep forrows difturbed their ghofts a.

2 Tu manes ne lade

That meos. 
That they buried their dead on their backs, or in a fupine pofition, feems agreeable unto profound fleep, and common pofture of dying; contrary to the moft naturall way of birth; Nor unlike our pendulous pofture, in the doubtfull ftate of the womb. Diogenes was fingular, who preferred a prone fituation

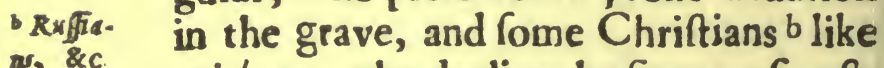
m, \&c. neither, who decline the figure of reft, and make choice of an erect pofture.

That they carried them out of the world with their feet forward, not inconfonant unto reafon : As contrary unto the native pofture of $\mathrm{man}$, and his production firft into it. And alfo agreeable unto their opinions, while they bid adieu unto the world, not to look again upon it; whereas Mabomet nns who think to return to a delightfull life again, are carried forth with their heads forward, and looking toward their houres.

They clofed their eyes as parts which firft die or firft difcover the fad effects of death. But their iterated clamations to excitate their dying or dead friend?, 


\section{Vrne-Buriall.}

or revoke them unto life again, was a vanity of affection; as not prefumably ignorant of the criticall tefts of death, by appofition of feathers, glaffes, and reflexion of figures, which dead eyes reprefent not; which however not ftrialy verifiable in frethand warm cadevers, could hardly elude the teft, in corps of four or five dayes.

That they fuck' $d$ in the laft breath of their expiring friends, was furely a practice of no medicall inftitution, but a loofe opinion that the foul paffed out that way, and a fondneffe of affection from fome * Pythagoricall foundation, thàt the fpirit of one body paffed into another; which they wilhed might be pompe futheir own.

That they powred oyle upon the pyre, was a tolerable practife, while the intention refted in facilitating the accenfion; But to place good Omens in the quick and Speedy burning, to facrifice unto the windes for a difpatch in this office, was a low form of fuperftition.

The Archimime or Fester attending the Funerall train, and imitating the freeches, gefture, and manners of the

* Franecfeo, Perucei. nebriz 
deceafed, was toolight for fuch folemnities, contradicting their Funerall Orations, and dolefull rites of the grave.

That they buried a peece of money with them as a Fee of the Elygan Ferriman, was a practife full of folly. But the ancient cuftome of placing coynes in confiderable Urnes, and the prefent practife of burying medals in the Noble Foundations of Earope, are laudable wayes of hiftoricall difcoveries, in actions, perfons, Chronologies; and pofterity will applaud them.

We examine not the old Laws of Sepulture, exempting certain perfons from buriall or burning. But hereby we apprehend that thefe were not the bones of perfons Planet-ftruck or burne with fire from Heaven : No Reliques of Traitors to their Gountrey, Self-killers, or Sacrilegious Malefactors; Perfons in old apprehenfion unworthy of the eartb; condemned unto the Tartara's of Hell, and bottomleffe pit of Plato, from whence there was no redemption.

Nor were only many cuftomes queftionable in order to their Obfequies, but allo 


\section{Urie-Busiall.}

alfo fundry practifes, fictions, and conceptions, difcordant or obfcure, of their ftate and future beings; whether unto eight or ten bodies of men to adde one of a woman, as being more inflammable, and unatuoully conftituted for the better pyrall combuftion, were any rationall practife: Or whether the complaint of Perianders Wife be tolerable, that wanting her Funerall burning the fuffered intolerable cold in Hell, 20cor: ding to the conftitution of the infernall houfe of Plato, wherein cold makes 2 great part of their tortures; it cannot paffe withont fome queftion.

Why the Female Ghofts appear unto vhyses, before the Heroes and mafculine Cpirits? Why the PSyche or foul of Tirefass is of the mafculine gender; who being blinde on earth fees more then all the reft in hell; Why the Funerall Suppers confifted of Egges, Beans,Smallage, and Lettuce, fince the dead are made to eat Afphodels about the Elyzian medows? Why fince there is no Sacrifice acceptable, nor any propitiation for the Covenant of the grave; men fet up the Deity of cMorta, and fruitlelly ado- 
red Divinities without ears? it cannot efcape fome doubt.

The dead feem all alive in the bumane Hades of Homer, yet cannot well fpeak, prophefie, or know the living, except they drink bloud, wherein is the life of man. And therefore the fouls of Penelope's Paramours conducted by Mersury chirped like bats, and thofe which followed Hercules made a noife but like a flock of birds.

The departed fpirits know things paft and to come, yet are ignorant of things prefent. Agamemnon foretels what thoul I happen unto 2 ly/es, yet ignorantly enquires what is become of his own Son. The Ghofts are afraid of fwords in $\mathrm{HO}$ mer, yet sybilla tels IEneas in Virgil, the thin habit of Pirits was beyond the force of weapons. The Ipirits put off their malice with their bodies, and Cafar and Porspey accord in Latine Heli, yet Ajax in Homer endures not a conference with Vlyfes: And Deiphobus appears all mangled in Virgils Ghofts, yet we meet with perfect thadows among the wounded ghofts of Hosser.

Since Charon in Lucian applauds his condi- 


\section{Vrne Buriall.}

condition among the dead, whether it be handfomely faid of Acbilles, that living contemner of death, that he had rather be a Plowmans fervant then Emperour of the dead? How Bercules his foul is in hell, and yet in heaven, and gultivs his foul in a Starre, yet feen by Emeas in hell, except the Ghofts were but Images and Thadows of the foul, re ceived in higher manfions, according to the ancient divifion of body, foul, and image or simulachrum of them both. The particulars of future beings muft needs be dark unto ancient Theories, which Chriftian Philofophy yet determines but in a Cloud of opinions. A Dialogue between two Infants in the womb concerning the ftate of this world, might handfomely illuftrate our ignorance of the next, whereof methinks we yet difcourfe in Platoes denne, and are but Embryon Philofophers.

Pythagor as efeapes in the fabulous hell of Dante a, among that fwarm of Philofophers, wherein whileft we ineet with Del inferno. c.uns.4. Plato and Secrases, Cato is to be found in no lower place then Purgatory. Among all the fet, Epicurus is moft confiderable, whom 
whom men make honeft without an $E i_{\text {y }}$ 。 zium, who conecmned life without encouragement of immortality, and making nothing after death, yet made nothing of the King of teriours.

Were the happineffe of the next world as clofely apprehended as the felicities of this, it were a martyrdome to live; and unto fuch as confider none hereafter, it muft be more then death to dye, which yot makes usiamazed at thofe audacities, that durft be nothing, and return into their chaos again. Certainly fuch fpirits as could conternn death, when they expected no better being after, would have fcorned to live had they known any. And therefore we applaud not the judgment of Macbiavel, that Chriftianity makes men cowards, or that with the confidence of but half dying, the defpi fed virtues of patience and humility, have abafed the fpirits of men, which Pagan principles exalted, but rather regulated the wildeneffe of audacities, in the attempts, grounds, and eternall fequels of death; wherein men of the boldeft fpirits are often prodigiouly teanerarious. Nor can we extenuate the deomenes valour 
valour of ancient Martyrs, who contemned death in the uncorimfortable feene

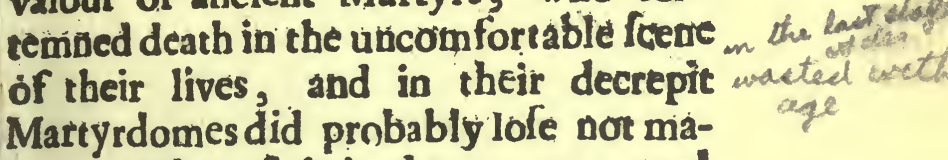
by moneths of their dayes, or parted with life when it was fearce worth the living. For (befide that long time paft holds no confideration unto a flender time to come) they had no fmall difadvantage from the conftitution of old age, which naturally makes men fearfull ; And complexionally fuperannuaated from the bold and couragious ethoughts of youth and fervent years. But the contempt of death from corpotrall animofity, promoteth not our fealicity. They may fet in the OrchePras, and nobleft Seats of Heaven, who have held up thaking bands in the fire, and humanely contended for glory.

Mean while Epicur us lyes deep in Dante's hell, wherein we meet with Tombs enclofing fouls which denied heir immortalities. But whether the wirtuous heathen, wholived better then he fpake, or erring in the principles of

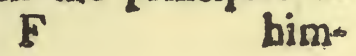


himfelf, yet lived above Philofophers of more fpecious Maximes, lye fo deep as he is placed; at leaft fo low as not to rife againft Chriftians, who beleeving or knowing that truth, have laftingly denied it in their practife and converfation, were a quxery too fad to in. fift on,

But all or moft apprehenfions refted in Opinions of fome furure being, which ignorantly or coldly beleeved, begat thofe perverted conceptions, Ceremonies, Sayings, which Chriftians pity or laugh at. Happy are they, which live not in that difadvantage of time, when men could ray little for futurity, but from reafon. Whereby the nobleft mindes fell often upon doubtfull deaths, and melancholly Diffolutions; With thefe hopes Socrates warmed his doubtfull fpirits, againft that cold potion, and $C_{\text {ato }}$ before he durft give the fatall ftroak fpent part of the night in reading the immortality of Plato, thereby confirming his wavering hand unto the animofity of that attempt. 


\section{Vrne Buriall.}

It is the heavieft ftone that melan. choly can throw at a man, to tell him he is at the end of his nature; or that there is no further ftate to come, unto which this feemes progreffionall, and otherwife made in vaine; Without this accomplifhment the naturall expectation and defire of fuch a ftate, were but a fallacy in nature, unfatisfied Confiderators; would quarrell the jutice of their conftitutions, and reft content that Adam had fallen lower, whereby by knowing no other Originall, and deeper ignorance of themfelves, they might have enjoyed the hiappineffe of inferionr Creatures; who in tranquility poffeffe their Conftitutions, as having not the apprebenfion to deplore their own natures. And being framed below the circumference of thefe hopes, or cognition of better being, the wifedom of God hath neceffitated their Contentment : But the fuperiour ingredient and obfcured part of our felves, whereto all prefent felicities afford no refting contentment, will be able at laft to

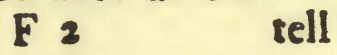


tell us we are more theu our prefent felves; and evacuate fuch hopes in the fruition of their own accomplifhments. 


\section{CHA P, V}

NOw fince thefe dead bones have 1 already out-lafted the living ones of Metbufelah, and in a yard under ground, and thin walls of clay, out-worn all the ftrong and fpecious buildings above it ; and quietly refted under the drums and tramplings of three conquelts; What Prince can promife fuch diuturnity unto his Reliques, or might not gladly fay,

* Sic ego componi verfus in offa velims. * Tibub Time which antiquates Antiguities, and hath an art to make duft of all things, hath yet fpared thefe minor Monuments. a oracule In vain we hope to be known by 0 - Cheldaice pen and vifible confervatories, when to cum Scbotiis pe unk we peli to be unknown was the means of their con- i borbonis. kinuation and obfeurity their protection: Bin nutiouIf they dyed by violent hands, and were 70 ov où If they dyed by violent hands, and were tuxai wa-

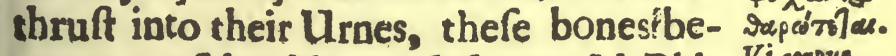
come confiderable, and fome old Phi- Vicorpus lofophers would honour a them, whofe relinquen. 
fouls they conceived moft pure, which were thus fnatched from their bodies; and to retain a ftranger propenfion unto them: whereas they weariedly left a languifhing corps, and with faint defires of re-union. If they fell by long and aged decay, yet wrapt up in the bundle of time, they fall into indiftinction, and make but one blot writh Infants, If we begin to die when we live, and long life be but a prolongation of death; our life is a fad compofition; We live with death, and die not in a moment. How many pulfes made up the life of Metbufelab, were work for Archimedes:

$D$ Ia the Pralme of Mofes. - According to the ancient $A$ rithmerick of the hund wherein the little singer of the righe hand contratied,fig . nified an hondred. Pierius in Aficroslypb. Common Counters fumme up the life of Unofes his man $b$. Our dayes become confiderable like petty fums by minute accumulations; where numerous fractions make up but fmall round numbers; and our dayes of a fpan long make not one little finger $e$.

If the nearneffe of our laft neceffity, brought a nearer conformity unto it, there were a happineffe in hoary hairs, and no calamity in half fenfes. But the long habit of living indifpofeth us for

dying 


\section{Urne-Buriall.}

dying; When Avarice makes us the fport of death; When even David grew politickly cruell; and Solomon could hardly be faid to be the wifett of men. But many are too early old, and before the date of age. Adverfity fretcheth our dayes, mifery makes * Alcmenas * One nights, and time hath no wings unto it. night as But the moft tedious being is that which can unwih it felf, content to be nothing, or never to have been, which was beyond the male-content of $\xi i b$, who curfed not the day of his life, but his Nativity: Content to have fo farre been, as to have a Title to future being; Although he had lived here but in an hidden ftate of life, and as it were an abortion.

What Song the Syrens fang, or what name Labilles affumed when he hid The puzhimfelf among women, though puzling Queftions are not beyond all conjecture. What time the perfons of thefe Olfuaries entred the famcus Nations of the dead, and flept with Princes and Counfellours, might admit a wide folution. Butlours, might admit a wide folution, vsa vexgãy bones, or what bodies thefe alhes made $g_{0}$.
bons

$$
\text { F } 4 \text { up, }
$$

ling quefi. ons of $\mathrm{T} i$. berius unto Grammsrians. Marcel. Donatus in Suet. Kavide हैo. 
up, were a queftion above Antiquarifm. Not to be refolved by man, nor eafily perhaps by fpirits, except 'we confult the Provinciall Guardians, or tutellary Obfervators. Had they made as good provifion for their names, as they have done for their Reliques, they had not fo grofly erred in the art of perpetuation. But to fubfift in bones, and be but Pyramidally extant, is a fallacy in duration. Vain afhes, which in the oblivion of names, perfons, times, and fexes, have found unto themfelves, a fruitleffe continuation, and only arife unto late pofterity, as Emblemes of mortall vanities; Antidotes againft pride, vainglory, and madding vices. Pagan vainglories which thought the world might laft for ever, had encouragement for ambition, and finding no Atropos unto the immortality of their Names, were never dampt with the neceffity of oblivion. Even old ambitions had the advantage of ours, in the attempts of their vain-glories, who acting early, and before the probable Meridian of time, have by this time found great accom- 
plifhment of their ddfignes, whereby the ancient Heroes have already out-lafted their Monuments, and Mechanicall prefervations. But in this latter Scene of time we cannot expect fuch Mummies unto our memories, when ambition may fear the Prophecy of Elias $\mathrm{e}$, and charles the fifth can never hope to live within two Metburela's of Hectorf.

And therefore reftleffe in quietude for the diuturnity of our memories unto prefent confiderations, feems a vanity almoft out of date, and fuperanuated peece of folly. We cannot hope to live fo long in our names, as fome have done in their - That the world may laft but fix thoufand years. f Heârs fame lafting above two lives of Metbufelab, before that famous

Priace was extant. perfons, one face of fanus holds no proportion unto the other. "Tis too late to be ambitious. The great mutations of the world are acted, or time may be too thort for our defignes. To extend our memories by Monuments, whofe death we dayly pray for, and whofe duration we cannot hope, without injury to our expectations, in the advent of the laft day, were a contradiction to our beliefs. We whofe generations are ordained in this fetting part of time, are provi- 
providentially taken off from fuch $\mathrm{i}$. maginations. bAnd eing neceffitated to eje the remaining particle of futurity, are naturaliy conftituted unto thoughts of the next world, and cannot excufaby decline the confideration of that duration, which maketh Pyramids pillars of now, and all that's paft a momerit.

Circles and right lines limit and clofe all bodies, and the mortall right-lined :0 The circle g, muft conclude and thut up all. charater There is no antidote againft the opium of death. of time, which temporally confidereth all things; Our Fathers finde their graves in our thort memories, and fadly tell us how we may be buried in our Survivors. Grave-ftones tell truth fcarce

- old ones being ta. ken up, and other bo. dies laid under them i Gruteri InScriptiones Antique.

fourty years $\mathrm{h}$ : Generations paffe while fome trees ftand, and old Families laft not three Oaks. To be read by bare Inferiptions like many in Gruteri , to hope for Eternity by Ænigmaticall Epithetes, or firft letters of our names, to be ftudied by Antiquaries, who we were, and have new Names given us like many of the Mummies, are cold 
confolations unto the Students of perpetuity, even by everlafting Languages.

To be content that times to come thould only know there was fuch a man. not caring whether they knew more of him, was a frigid ambition in Cardan k: difparaging his horofcopal inclination and judgement of himfelf, who cares to fubfift like Hippocrases Parients, or Acbilles horfes in Homer, under naked nominations, without deferts and piopris. noble acts, which are the halfame of our memories, the Entelecbia and foul of our fubfiftences. To be nameleffe in worthy deeds exceeds an infamous hiftory. The Canaanitifh woman lives more happily without a name, then $\mathrm{He}$ rodias with one. And who had not rather have been the good theef, then Pilate?

But the iniquity of oblivion blindely Icattereth her poppy, and deals with the memory of men without difinction to merit of perpetuity, Who can but pity the founder of the Pyramids? Heroftrains lives that burnt the Temple of Dir

- Caperem notwom effe quod frm, non opto $x t$ fciarur quaGis frm.

Card in vire 
$n a$, he is almoft loft that built it ; Time hath fpared the Epitaph of Adrasins horfe, confounded that of himfelf. In vain we compute our felicities by the advantage of our good names, fince bad have equall durations; and Therfites is like to live as long as Agamemnon, without The favour of the everlafting Regifter: Who knows whether the beft of men be known? or whether there be not more remarkable perfons forgot, then any that ftand remembred in the known account of time? the firlt man had been as unknown as the laft, and Methuselabs long life had been his only Chronicle. Oblivion is not to be hired: The greater part muft be content to be as though they had not been, to be found in the Regilter of God, not in the record of man. Twenty feven Names make up the firt ftory, and the recorded names ever fince contain not one living Century. The number of the dead long exceedeth all that thall live. The night of time far furpaffeth the day, and who knows when was the Elquinox? Euery houre addes unto that current Arithmetique, which fcarce ftands one moment, And fince 


\section{Vrne-Buriall.}

fince death muft be the Lucina of life, and even Pagans could doubt whether thus to live, were to dye. Since our longeft Sunne fets at right defcenfions, and makes but winter arches, and therefore it cannot be long before we lie down in darkneffe, and have our light in afhes. Since the brother of death daily haunts us with dying memento's, and time that grows old it felf, bids us hope no long duration: Diuturnity is a drean and folly of expectation.

Darkneffe and light divide the courfe of time, and oblivion thares with memory, a great part evers of our living beings; we flightly remember our feliciries, and the fmarteft Atroaks of affliCtion leave but Thort fmart upon us. Senfe endur eth no extremities, and forrows deftroy us or themfelves. To weep into ftones are fables. Afflictions induce callofities, miferies are lippery, or fall like fnow unou us, which notwithftand. ing is no unhappy ftupidity. To be ignorant of evils to come, and forgetfull of evils paft, is a mercifull provifion in nature, whereby we digeft the mixture 


\section{Hydriotaphia;}

of our few and evil dayes, and our delivered fenfes not relapfing into cutting remembrances, our forrows are not kept raw by the edge of repetitions. A great part of Antiquity contented their hopes of fubfiftency with a tranfmigration of their fouls. A good way to continue their memories, while having the advantage of plurall fucceffions, they could not but act fomething remarkable in fuch variety of beings, and enjoying the fame of their palfed felves, make accumulation of glory unto their laft durations. Others rather then be loft in the uncomfortable night of nothing, were content to recede into the common being, and make one particle of the pub. lick foul of all things, which was no more then to return into their unknown and * Ommia ve divine Originall again. Egyptian ingenitios 6 pa- nuity was more unfatisfied, contriving muni àvitheir bodies in fweet confiftences, to at$\mu \times, \beta i s \times n$. os ut olim Aquila d Symmectbos. v. Druf. Eccks. terd the return of their fouls. But all was vanity, feeding * the winde, and folly. The Fegyptian Mummies, which cambyses or time hath Spared, avarice now confumeth. Mummie is become 
Merchandife, Mizraim cures wounds, and Pharaob is fold for balloms.

In vain do individuals hope for Immortality, or any patent from oblivion, in prefervations below the Moon : Men have been deceived even in their flatteries above the Sun, and frudied conceits to perpetuate their names in heaven. The various Cofmography of that part hath already varied the names of contrived conftellations; Reimrod is loft in Orion, and Ofyris in the Dogge-ftarre. While we look for incorruption in the heavens, we finde they are but like the Earth; Durable in their main bodies, alterable in their parts: whereof befide Comets and new Stars, perfpectives begin to tell tales. And the fpots that wander about the Sun, with Pbaetons favour, would make clear conviction.

There is nothing Atrictly immortall, but immortality; whatever hath no beginning may be confident of no end. All others have a dependent being, and within the reach of deftruction, which is the peculiar of that neceffary effence that cannot deftroy it felf; And the higheft 
higheft ftrain of omniposency to be fo powerfully conftituted, as not to fuffes even from the power of it felf. But the fufficiency of Chriftian Immortality fruftrates all earthly glory, and the quality of either ftate after death, makes a folly of pofthumous memory. God who can only deftroy our fouls, and hath affured our refurrection, either of our bodies or names hath directly promifed no duration. Wherein there is fo much of chance that the boldeft Expectants have found unhappy fruftration; and to hold long fubfiftence, feems but a fcape in oblivion. But man is a Noble Animal, Splendid in afhes, and pumpous in the grave, folemnizing Nativities snd Deaths with equall luftre, nor omitting Ceremonies of bravery, in the infamy of his nature.

Life is a pure flame, and we live by an invifible Sun within us. A fmall fire fufficeth for life, great flames feemed too little after death, while men vainly affected precious pyres, and to burn like Sardanapalus, but the wifedom of funerall Laws found the folly of prodigall blazes, 
blazes, and reduced undoing fires, unto the rule of fober obfequies, wherein few could be fo mean as not to provide wood, pitch, a mourner, and an Urne.

Five Languages fecured not the Epitaph of Gordianus; The man of God lives longer without a Tomb then any by one, invifibly interred by Angels, and adjudged to obfcurity, though not without fome marks directing humane difcovery. Enoch and Elias without either tomb or buriall, in an anomalous ftate of being, are the great Examples of perpetuity, in their long and living memory, in ftrict account being ftill on this fide death, and having a late part yet to act upon this ftaye of earth. If in the decretory term of the world we thall not all dye but be changed, according to received tranllation; the laft day will make but few graves; at leaft quick RefurreCtions will anticipate lafting Sepultures; Some Graves will be opened before they be quite clofed, and Lazarus be no wonder. When many that feared to dye thall groane that they can dye G but 
2 Fornandes de rebus Ge. ticis.

:16.14.

but once, the difmall ftate is the fecond and living death, when life puts defpair on the damned; when men thall with the coverings of Mountaines, not of Monuments, and annihilation thall be courted.

While fome have ftudied Monuments, others have ftudiouly declined them: and fome have been fo vainly boifterous, that they durft not acknowledge their Graves; wherein b Alaricus feems moft fubtle, who had a River turned to hide his bones at the bottome. Even sylla that thought himfelf fafe in his Urne, could not prevent revenging tongues, and ftones thrown at his Monument. Happy are they whom privacy makes innocent, who deal fo with men in this world, that they are not afraid to meet them in the next, who when they dye, make no commotion among the dead, and are not touche with that pocticall taunt of I/aiab c.

Pyramids, Arches, Obelisks, were but the irregularities of vain-glory, and wilde enormities of ancient magnanimity. But the Imoft magnanimous refolution refts 
in the Chriftian Religion, which trampleth upon pride, and fets on the neck of ambition, humbly purfuing that infallible perpetuity, unto which all others muft diminifh their diameters, and be poorly feen in Angles of contingency d.

Pious fpirits who paffed their dayes in raptures of futurity, made little more of this world, then the world that was beAngulus contingentie, the leaft of Angles. fore it, while they lay obfcure in the Chaos of pre-ordination, and night of their fore-beings. And if any have been fo happy as truly to underftand Chriftian annihilation, extafis, exolution, liquefaction, transformation, the kiffe of the Spoure, guftation of God, and ingreffion into the divine thadow, they have already had an handfome anticipation of heaven; the glory of the world is furely over, and the earth in afhes unto them.

To fubfift in lafting Monuments, to live in their productions, to exift in their names, and predicament of Chymera's, was large fatisfaction unto old expectations, and made one part of their Elyziwnss. But all this is nothing in the Metaphyficks of true belief. To live indeed 


\section{4 \\ Hydriotapbia,}

I In Paris is to be again our felves, which being not where bodies foon confume. f A ftately Maufoleum or fepulchral pyle built by $A$. drianus in Rome, where now ftandeth the Caftle of S:Angelo only an hope but an evidence in noble beleevers; 'Tis all one to lye in St Innocents C Church-yard, as in the Sands of 正zJpt: Ready to be any thing, in the extafie of being ever, and as content with fix foot as the Moles of Adrianus $f$.

\section{Lucan}

Tabesne cadaver a Solvat

An rogus band refert. 


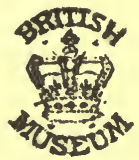




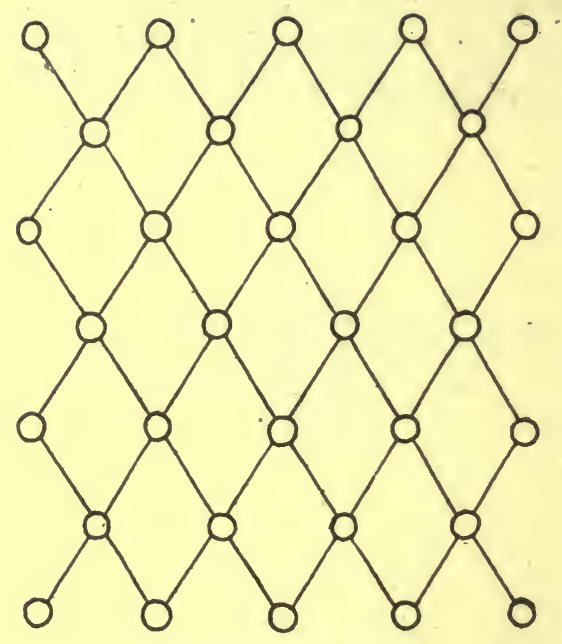

luid Quin cunce Jpeciofius, qui, in quam cungs partem Jectaueris, rectus est: Quintilian:" 


\section{THE \\ G A R D E N \\ OF}

$C \mathscr{R} \cup S$.

O R,

The Quincunciall,Lozenge, or Net-work Plantations of the Ancienrs, Artificially Naturally, Myftically Confidered.

B Y

Thomas Brown D. of Phyfick

Printed in the Year, 1658. 

เ

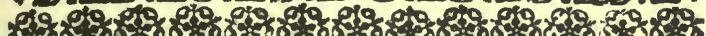

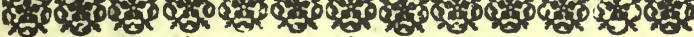

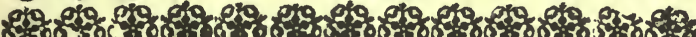
4 .

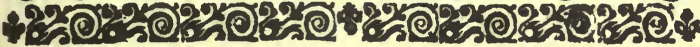

The Garden of Cyrus. OR.

The Quincunciall, Lozenge, or Net-work Plantations of the Anci ents, Artificially, Naturally, My fically confidered.

\section{CHAPTER I.}

Gent Vulcan gave arrows unto A Apollo and Diana the fourth 3a) $2 \mathrm{e}$ day after their Nativities, according to Gentile Theology, may paffe for no blinde apprehenfion of the Creation of the Sunne and Moon, in the work of the fourth day; When the diffufed light contracted into Orbes, 
and hooting rayes, of thofe Luminaries. Plainer Defcriptions there are from Pagan pens, of the creatures of a Plato in Timen. the fourth day; While the a divine Philofopher nnhappily omitteth the nobleft part of the third; And ovid ( whom many conceive to have borrowed his defcription from Mofes ) coldly deferting the remarkable account of the text, b fronde ueg in three words ${ }^{b}$, defcribeth this work filvas. of the third day; the vegetable creation, and firft ornamentall Scene of nature; the primitive food of animals, and firt ftory of Phyfick, in Dietetical confervation.

For though Phyfick may pleade high, from that medicall act of God, in cafting fo deep a fleep upon our firft $\mathrm{Pa}$ -

- draisenss, in opening the flelh. ¿quipsors, in taking out the rib.

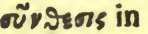
clofing up the part agdin. rent; And Chirurgery c finde its whole art, in that one paffage concerning the $\mathrm{Rib}$ of Adam, yet is there no rivality with Garden contrivance and Herbery: For if Paradife were planted the third day of the Creation, as wifer Divinity concludeth, the Nativity thereof was too early for Horofcopie; Gardens were before Gardiners, and but fome hours after the earth. 


\section{The Quincunx.}

Of decper donbt is its Topography, and locall defignation, yet being the primitive garden, and without much d controverfie feated in the Eaft; it is more then probable the firft curiofity, ambiguity and cultivation of plants, moft flourihed in thofe quarters. And finee the Ark of $20 a b$ firft toucht upon fome mountains of Armenia, the planting art arofe a For fome there is of the word Mikedem, whether $a b$ oriente or a again in the Eaft, and found its revolution not far from the place of its Nativity, about the Plains of thofe Regions. And if Zoroafter were either Chom, Cbus, or Mizraim, they were early proficients therein, who left (as Pliny delivereth) a work of Agriculture.

However the account of the Penfill or hanging gardens yf Babylon, if made by Semiramis, the third or fourth from Nimrod, is of no flender antiquity; which being not framed upon ordinary levell of ground, but raifed upon pillars, adnitting under-paffages, we cannot accept as the fitft Babylonian Gardens; But a more eminent progrefs and advancement in that art, then any that went before it : Somewhat anfwering or hinting the old Opinion concerning Paradife it felf, with principio.

many 


\section{Cyrus-Garden, Or}

many conceptions elevated, above the plane of the Earth.

Nebuchodonofor whom fome will have. to be the famous Syrien King of Diodorus, beautifully repaired that City; and 3 Gofephus. fo magnificently built his a banging gardens; that from fucceeding Writers be had the honour of the firft. From whence over-looking Babylon, and all the Region about it, he found no circumfeription to the eye of his ambition, sill over-delighted with the bravery of this Paradife; in his melancholy metamorphofis, he found the folly of that delight, and a proper punifhment, in the contrary habitation, in wilde plantations and wandrings of the fields.

The Perfsan Gallants who deftroyed this Monarchy, maintained their Botanicall bravery. Unto whom we owe the very name of Paradife: wherewith we meet not in Scripturc before the time of Solomson, and conceived originally Peryans. The word for that dilputed Garden, expreffing in the Hebrew no more then a Field enclofed, which from the fame Root is content to derive a garden and a Buckler. 
Cyres the elder brought up in Wonds and Mountains, when time and power enabled, purfued the dictate of his education, and brought the treafures of the field into rule and circum-fcription. So nobly beautifying the hanging Gardens of Babylon, that he was alfo thought to be the authour thereof.

Abafwerus (whom many conceive to have been Artaxerxes Loxgi-manus ) in the b Countrey and City of Flowers, and in an open Garden, entertained his Princes and people, while Vaftbi more modeftly treated the Ladies within the Palace thereof.

But if (as fome opinion) King Abafuerus were-Artaxerxes Mnemon, that found a life and reign anlwerable unto his great b'suban in Sufana. memory, our magnified Cyrus was his fecond Brother: who gave the occation of that memorable work, and almolt miraculous retrait of Xersoplion. A perfon of high fpirit and honour, naturally a King, though fatally prevented by the harmleffe chance of $p o, b$-geniture: Not only a Lord of Gardens, but a manuall planterthereof : difpofing his trees like his armies in regular ordination. So

Plutarch in the life of Artaxerxes. 
that while old Laertas hath found a name in Homer for pruning hedges, and clearing away thorns and bryars; while King Attalus lives for his poyfonous plantations of Aconites, Henbane, Hellebore, and plants bardly admitted within the walls of Paradife; While many of the Ancients do poorly live in the fingle names of Vegetables; All ftories dolook upon Cyrus, as the fplendid and regular planter.

Xenophon in Deconomico.

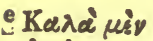
od d'viseg, di i

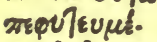
yos, of oo of oi sixos Tõy Sivşav, हैu= dabyea of minla xe$\lambda \omega ็$ s.

Ecicero ia Cat. Major.

According whereto Xenophon defcribeth his gallant plantation at Sardis, thus rendred by strebeus. e Arbores pari intervallo fit as, rectos ordines, of omnia perpulchre in Quincuncem directa. Which we thall take for granted as heing accordingly rendred by the moft elegant of the $f$ Latines; and by no made term, but in ufe before by Varro. That is the rows and orders fo handfomly difpofed; or five trees fo fet together, that a regular angularity, and through profpect, was left on every fide, Owing this name not only unto the Quintuple number of Trees, but the figure declaring that number. which being doubted at the angle, makes up the Letter $\chi$, that is the Em- 


\section{The Quincunx.}

phaticall decuffation, or fundamentall figure.

Now though in fome ancient and modern practice the area or decuffated plot, might be a perfect fquare, anfwerable to a Tuscan Pedeftall, and the 2uinquernio or Cinque-point of a dye; wherein by Diagonall lines the interfection was regular; accomodable unto Plantations of large growing Trees; and we muft not deny our felves the advantage of this order; yet thall we chiefly infift upon that of $g$ Curtius and Porta, in their brief defcription hereof. Wherein the decus/os is made within a longilaterall fquare, with oppofite angles, acute and 5 Benedia Curtius de Hortis.Bapto porta in vills. obtufe at the interfection; and fo upon progreffion making a Rbombus or Lozenge figuration, which feemeth very agreeable unto the Originall figure; $A n$ fwerable whereunto we obferve the decuffated characters in many confulary Coynes, and even in thofe of Conftantine and his Sons, which pretend their pattern in the Sky; the crucigerous Enfigne carried this figure, not tranfverly or rectangularly interlected, but in a decuffation, affer the form of an An- 


\section{Cyrus-Garden, Or}

drean or Burgundian crofs, which anfwereth this defcription.

Where by the way we fhall decline the old Theme, fo traced by antiquity of croffey and crucifixion: Whereof fome being right, and of one fingle peece without traverfion or tranfome, do lit. tle advantage our fubject. Nor thall we take in the myfticall $T a u$, or the Croffe of our bleffed Saviour, which having in fome defcriptions an Empedon or croffing foot-ftay, made not one fingle tranfverfion. And fince the Learned Lipfins hath made fome doubt even of the Croffe of St Ardrew, fince fome Martyrologicall Hiftories deliver his death by the generall Name of a croffe, and Hippolitus will have him fuffer by the fword; we fhould have enough to make out the received Croffe of that Martyr. Nor fhall we urge the labsrum, and famous Standard of Constantine, or make further ufe thereof, then as the firt Letters in the Name of our Saviour Chrift, in ufe among Chriftia Of Mari- ans, before the dayes of Conftantine, to der, Roma be obferved in a Sepulchral Monuments Solterranea. of Martyrs, in the Reign of $A \dot{d}$ rian, and Antoninus; 


\section{The Quincunx.}

Antoninus; and to be found in the Antiquities of the Gentiles, before the advent of Chrift, as in the Medall of King Ptolomy, figned with the fame characters, and might be the beginning of fome word or name, which Antiquaries have not hit on.

We will not revive the myfterious croffes of Egypt, with circles on their heads, in the breatt of serapis, and the hands of their Geniall fpirits, not unlike the character of Venus, and looked on by ancient Chriftians, with relation unto Chrift. Since however they firft began, the Egyptians thereby expreffed the proceffe and motion of the fpirit of the world, and the diffusion thereof upon the Celeftiall and Elementall nature; implyed by a circle and right-lined interfection. A fecret in their Telefmes and magicall Characters among them. Though he that confidereth the ${ }^{b}$ plain crofle upon the head of the Owl in the Laterane Obelisk, or the ${ }^{c}$ crolfe erected upon a picher diffufing ftreams of water into two bafins, with fprinkling branches in them, and all defcribed upon a two-footed Altar, as in the Hierogly-

b wherein the lower part is fome what longer, as defined by Upton de ftudio militari, and Yobannes de Bado Aureo; cum com. ment.clarif: er doctios. Bifai. - Cafal.dé Ritibus. Bofro nella Trionfazise croce. 
phicks of the brafen Table of Bembus; will hardly decline all thought of Chriftian fignality in them.

We fhall not call in the Hebrew Tensphe, or ceremony of their Oblations, waved by the Prieft unto the four quarters of the world, after the form of a crols; as in the peace-offerings. And if it were clearly made out what is remarkably delivered from the Traditions of the Rabbins, that as the Oyle was powred coronally or circularlly upon the head of Kings, fo the High-Prieft was anointed decuffatively or in the form of a $\mathrm{X}$; though it could not efcape a typicall thought of Chrift, from myfticall confaderators; yet being the conceit is Hebrew, we thould rather expect its verification from Alalogy in that language, then to confine the fame unto the unconcerned Letters of Greece, or make it out by the characters of Cadmoss or Palamedes.

Of this Quincunciall Ordination the Ancients practifed much difcourfed little; and the Moderns have nothing enlarged; which he that more nearly confidereth, in the form of its fquare $R$ bom- 


\section{The Quincunx.}

bus, and decuffation, with the feverall commodities, myfteries, parailelifmes, and refemblances, both in Art and $\mathrm{Na}$ ture, Thall eafily difcern the elegancy of this order.

That this was in fome wayes of praEtice in diverfe and diftant Nations, hints or deliveries there are from no flender Antiquity. In the hanging Gardens of Babylon, from Abydenus, Enfebrus, and others, d Curtius defcribeth this Rule of decuffation. In the memorable Garden of Alcinous anciently conceived an originall phancy, from Paradile, mention there is of well contrived order; For fo Horrar. 1.6. hath Didymus and Eustacbius expounded the emphatical word. Diomedes defcribing the Rurall poffeffions of his father, gives account in the fame Language of Trees orderly planted. And vlyges being a boy was promifed by his Father

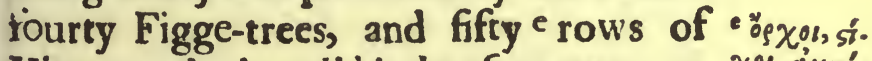

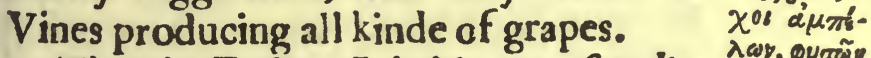

That the Eaftern Inhabitants of India, six o os, in made ufe of fuch order, even in open Plantations, is deducible from Theophra-

flus; who defcrribing the trees whereof Philoxenus they made their garmeats, plainly deli$\mathrm{H}_{3}$ vereth $\mathrm{H}_{3}$ vereth

d Decufatio ir $\int a$ jucun. dum ac peramanum conSpellum prebutt. Cart.

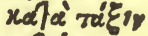
Фข'हia. 
vereth that they were planted $x a l^{\prime}$ " $p \chi^{8} \xi_{s}$ and in fuch order that at a diftance men would miftake them for Vineyards. The fame feems confirmed in Creece from a Eousaides dertidiv. Politi. fingular expreffion in $\mathrm{f}$ Ariftotle concerning the order of Vines, delivered by a military term reprefenting the orders of Souldiers, which alfoconfirmeth the antiquity of this form yet ufed in vineall plantations.

That the fame was ufed in Latine plantations is plainly confirmed from the commending penne of Varro, Quintilian, and handfome Defcription of 8 Indilge ore g Virgil.

dinzbus, nec fecius omnis in urgusm Arboribus pofiris, fecto via limite. quadree. Gecrg.2.

That the firft Plantations not long after the Floud were difpofed after this manner, the generality and antiquity of this order obferved in Vineyards, and Wine plantations, affordeth fome conjecture. And fince from judicious enquiry, Saturn who divided the world between his three ftones, who beareth a Sickle in his hand, who taughe the plantations of Vines, the ferting, grafting of trees, aud the beft part of Agriculture, is difcovered to be Keah, whether this early difperfed Husbandry in 


\section{The Quincurnx.}

Vineyards, had not its Originall in that Patriarch, is no fuch Paralogicall doubt.

And if it were clear that this was ufed by 2 oab after the Floud, I could eafily beleeve it was in ufe before it; Not willing to fix fuch ancient inventions no higher originall then Noab; Nor readily concaiving thole aged Heroes, whole diet was vegetable, and only, or chietly confifted in the fruits of the earth, were much deficient in their fplendid cultivations; or after the experience of fifteen hundred years, left much for future difcovery in B stanicall Agriculture, Nor fully perfwaded that Wine was the invention of Noab, that fermented Liquors, which often make themfelves, fo long efcaped their Luxury or experience; that the firft finue of the new world was no fin of the old. That Cain and $A$ bel were the firt that offered $\mathrm{Sa}$ crifice; or becaule the Scripture is (1lent that Adam or I/aac offered none at all.

Whether Abrabarn brought up in the firft planting Countrey, obferved not fom a rule hereof, when he planted a 
grove at Beer-heba; or whether at leaft a like ordination were not in the Garden of Solomon, probability may conteft. Anfwerably unto the wifedom of that eminent Botanologer, and orderly difpofer of all his other works. Efpecially fince this was one peece of Gallantry, wherein he purfued the fpecious part of felicity, according to his own defcription. I made me Gardens and Orchards, and planted Trees in them of all kindes Ecccler. 2. of fruit. I made me Pools of water, to water therewith the wood that bringeth forth Trees, which was no ordinary plantation, if according to the Targam, or Chaldee Parapbrafe, it contained all kindes of Plants, and fome fetched as far as India; And the extent thereof were from the wall of Ferufalem unto the water of Siloab.

And if Fordan were but Faar Eden, that is, the Riuer of Eden, Genefar but Ganfar or the Prince of Gardens; and it could be made out, that the Plain of fordans were watered not comparatively, but caufally, and becaufe it was the Paradife - Vet. Teffa- of God, as the Learned a Abrames hintmenti Pharuss. eth, he was not far from the Prototype ins and 
and originall of Plantations. And fince even in Paradife it felf, the tree of knowledge was placed in the middle of the Garden, whatever was the ambient figure, there wanted not a centre and rule of decuifation.? Whether the groves and facredPlantations of Antiquity, were not thus orderly placed, either by quaternio's, or quintuple ordinations, may favourably be doubted. For fince they were fo methodicall in the conftitutions of their temples, as to obferve the due fcituation, afpect, manner, form, and order in Architectonicall relations, whether they were not as diftinct in their groves and Plantations about them, in form and $\beta$ ecies refpectively unto their Deities, is not without probability of conjecture.And in their groves of the Sunne this was a fit number, by multiplication to denote the dayes of the year; and might Hieroglyphically fpeak as much, as the myfticall statua of d Janus in the Language of his fingers. And fince they were fo criticall in the number of his horles, the ftrings of his Harp, and rayes about his head, denoting the orbes

d Which King Numa fet up with hisfingers fo difpofed that they numerical$\mathrm{H}_{4}$ of 365 Pling. 
of heaven, the Seafons and Moneths of the Yeare; witty Idolatry would hardly be flat in other appropriations. 


\section{CH A P II}

NOr was this only a form of practife 1 in Plantations, but found imitation from high Antiquity. in fundry artificiall contrivances and manuall operations. For to omit the pofition of fquared Atones, cuneatim or wpedgmije in the Walls of Roman and Gotbick buildings; and the lithoffrata or figured pavements of the ancients, which confifted not all of fquare ftones, but were divided into triquetrous fegments, honey-combs, and fexangular figures, according to Vitrwviws; The fquared ftones and bricks in ancient fabricks, were placed after this order. And two above or below conjoyned by a middle ftone or Plintbus, obfervable in the ruines of Forum Nexva, the CMaufolewm of eAnguftus, the Pyramid of ceftius, and the fculpture $d$ raughts of the larger Pyramids of $\bar{E}-$ gypt. And therefore in the draughts of eminent fabricks, Painters do commonly 


\section{6 \\ Cyrus-Garden, Or}

monly imitate this order in the lines of their defcription.

In the Laureat draughts of fculpture and picture, the leaves and foliate works are commonly thus contrived, which is but in imitation of the Pulvinaria, and ancient pillow-work, obfervable in 10nick peeces, about columns, temples and altars. To omit many other analogies, in Architectonicall draughts, which art

- Of a firacture five parts, Fundementmm, it felf is founded upon ${ }^{b}$ fives, as having its fubject, and moft gracefull peeces divided by this number.

parietes, A-

perture, Compartitio, tudum, Leo. Alberti. Five Columes, Tufcm, Dorick, Ionick, Corintbian, Compornd. Five different intercolumniations, Pycneftylos, dyftylos,Syffylos, Ar coffylos, Euftylos. vitur.

The Triumphal Oval, and Civicall Crowns of Laurel, Oake, and Myrtle, when fully made, were pleated after this order. And to omit the croffed Crowns of Chriftian Princes; what figure that was which Anaftatius defcribed upon the head of Leo the third; or who firft brought in the Arched Crown; That of Charles the great, (which feems the firft remarkably clofed (rown,) was 
The Quincunx Artificially Cobfidered

framed after this c manner; with an in- c vit conterfection in the middle from the main fat exper-

croffing barres, and the interfpaces, unto the frontal circle, continued by handlome network-plates, much after this order. Whereon we thall not inlift, beganene opud chifflet; in in $\mathbf{B}$. $\mathbf{R}$. Bruxelli, \& Icon. f. caufe from greater Antiquity, and practice of confecration, we meet with the radiated, and ftarry Crown, upon the head of Auguffus, and many fucceeding Emperors. Since the Armenians and Parthians had a peculiar royall Capp; And the Grecians from Alexander another kinde of diadem. And even Diadems themfelves were but fafciations, and handfome ligatures, about the heads of Princes; nor wholly omitted in the mitrall Crown, which common pieture feems to fet too upright and forward upon the head of Aaron: Worne fometimes fingly, or doubly by Princes, according to their Kingdomes; and no more to be expected from two Crowns. at once, upon the head of Ptlomy. And fo eafily made out when hiftorians tell us fome bound up wounds, fome hang- ale speem. us, fome bound up wounds, fome hang- Afpilog. \&
ed themfelves with diadems.
erudid. 
The beds of the antients were corded fomewhat after this fathion: That is not directly, as ours at prefent, but obliquely, from fide to fide, and after the manner of network; whereby they ftrengthened the fpondx or bedlides, and fperit lefs cord in the work : as is demonftrated e Arifor. by e Blancanus. Mechen. exaft.

And as they lay in croffed beds, fo they fat upon fceming croffelegg'd feats: in which form the nobleft thereof were framed: Obfervable in the triumphall feats, the fella curulis, or Edyle Chayres, in the coyns of Ceftuis, Sylla, and Fulius. That they fat alfo croffe legg'd many noble draughts declare; and in this figure the fitting gods and goddeffes are drawn in medalls and medallions. And befide this kinde of work in Retiarie and hanging textures, in embroteries, and eminent needle-works; the like is obvious unto every eve in glals-windows. Nor only in Glaffie contrivances, but allo in Lattice and Stone-work, conceived in the Temple of Solomon; wherein the dxanow. windows are termed feneftre reticulate, or lights framed like nets. And agreea- 


\section{The Quincunx Artificially Confidered 109}

ble unto the Greek expreffion concerning Chrift in the $\mathrm{m}$ Canticles, looking $\mathrm{m}$ Cann 2. through the nets, which ours hath rendered, he looketh forth at the windows, Thewing himfelfe through the latteffe; that is, partly feen and unfeen, according to the vifible and invifible fide of his nature. To omit the noble reticulate work, in the chapters of the pillars of Solomon, with Lillies, and Pomegranats upon a network ground; and the Craticula or grate through which the athes fell in the altar of burnt offerings.

That the networks and nets of antiquity were little different in the form from ours at prefent, is confirmable from the nets in the hands of the Retiarie gladiators, the proper combatants with the fecutores. To omit the ancient Conopeion or gnatnet, of the Egyptians, the inventors of that Artifice : the ruiney labyrinths of Theocritus; the nolegaynets, which hung from the head under the noftrils of Princes; and that uneafie metaphor of Reticulum Jecoris, which fome expound the lobe, we the caule above the liver. As for that famous network of

Vulcan: 


\section{0}

\section{Cyrus-Garden, Or}

Vulcan, which incloled Mars and Venus,

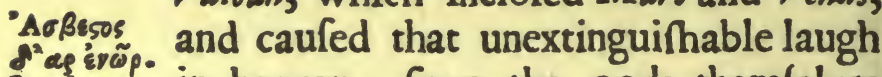
jo yidos. in heaven; fince the gods themlelves Hom. could not dilcern it, we thall not prie into it; Although why Vulcan bound them, Neptune loofed them, and Apollo fhould firft difcover them, might afford no vulgar mythologie. Heralds have not omitied this order or imitation thereof, whiles they Symbollically adorn their Scuchions with Mafcles Fufils and Saltyrs, and while they difpofed the figures of Ermins, and vaired coats in this Quincuncial method.

The fame is not forgot by Lapidaries while they cut their gemms pyramidally, or by xquicrural triangles. Perfpective pictures, in their Bafe, Horifon, and lines of diftances, cannot efcape thefe Rhomboidall decuffations. Sculptors in their ftrongeft Thadows, after this order do draw their double Haches. And the very Americans do naturally fall upon it, in their neat and curious textures, which is alfo obferved in the elegant artifices of Europe. But this is no law unto the woof of the neat Retiarie Spider, 
The Quincunx Artificially Confidered in I

which feems to weave without traniverfion, and by the union of right lines to make out a continued furface, which is beyond the common art of Textury, and may ftill nettle Mincrva the Goddeffe of that myfery. And he that thall hatch the little feeds, either found in fmall webs, or white round Egges, carried under the bellies of fome Spiders, and behold how as their firft production in boxes, they will prefently fill the fame with their webbs, may obferve the early, and untaught finger of nature, and how they are natively provided with a ftock, fufficient for fuch Texture.

The Rurall charm againft Dodder, $T$ etter, and Arangling weeds, was contrived after this order, while they placed a chalked Tile at the four corners, and one in the middle of their fields, which though ridiculous in the intention, was rationall in the contrivance, and a good way to diffure the magick through all parts of the cavea.

Somewhat after this manner they ordcred the little frones in the old game of As in the contention between Minerva and Aracbne. 


\section{Cyrus-Garden, Or}

Pentalitbifmus, or cafting up five ftones to catch them on the back of their hand. And with fome refemblance hereof, the Proci or Prodigall Paramours difpoled b In Euffac their men, when they played at b Persechius. lope. For being themfelves an hundred and eight, they fet fifty four ftones on either fide, and one in the middle, which they called Penelope, which he that hit was mafter of the game.

In Cheffe-boards and Tables we yet finde Pyramids and Squares, I wilh we had their true and ancient defcription, farre different from ours, or the chet mat of the Perfians, and might continue fome elegant remarkables, as being an inven-

Plato. tion as High as Hermes the Secretary of OSyris, figuring the whole world, the motion of the Planets, with Eclipfes of Sunne and Moon.

Phyficians are not without the ufe of this decuffation in feverall operations, in ligatures and union of diffolved continuities. Mechanicks make ufe herenf in forcipall Organs, and Inftruments of Incifion; wherein who can but magnifie the power of decuffation, infervient to 


\section{The Quincunx Artificially Confidered II3}

contrary ends, folution and confulidation, unioil, and divifion, illuftrable from Ariffotle in the old Nucifragium or Nutcracker, and the Inftruments of Evulfion. compreffion or incifion; which confitting of two Vectes or armes, converted towards each other, the innitency and ftrelie being made upon the bypom maciblion or fulciment in the deculfation, the greater compreffion is made by the union of two impulfors.

The Roman b Batalin was ordered afier this manner, whereof as fufficiently known Virgil hach left but an hint, and oblcure intimation. For thus were the maniples and cohorts of the Haftati, Priscipes and Triarii placed in their bodies, the $\mathrm{Em}$ wherein confifted the ftrength of the perours. Salmas. in the a Mounfieur de Peysefo \& de Re militari Romanorum. the Republike, before the divifion of the Legion in. toten Co- 
Roman battle. By this Ordination they

Kant
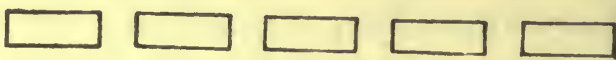

$\boldsymbol{P}^{\boldsymbol{r}}$.
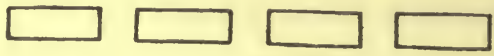

Tr.
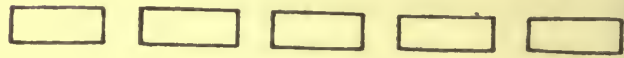

readily fell into each other; the $\mathrm{Hafla}$ ti being preffed, handfomely retired into the intervalls of the principes, thefe into that of the Triarii, which making as it were a new body, might joyntly renew the battle, wherein confifted the fecret of their fucceffes. And therefore c Polybius it was remarkably c fingular in the battle of Africa, that Scipro fearing a rout from the Elephants of the Enemy, left not the Principes in their alternate diftances, whereby the Elephants paffing the vacuities of the Haflati, might have mu upon them, but drew his battle into 
The Quincunx Artificially Confidered 115

right order, and leaving the paffages bare, defeated the mifchief intended by the Elephants. Out of this figure were made too remarkable forms of $B$ attle, the Cuneas and Forceps, or the theare and wedge hattles, each made of half a $R$ bombus, and but differenced by pofi. tion. The wedge invented to break or work into a body, the forceps to environ and defeat the power thereof, compo: fed out of the felecteft Souldiery and difpofed into the form of an $V$, wherein receiving the wedge, it inclofed it on both fides. After this form the famous d $\mathcal{N}$ aßes ordered his battle againft the Franks, and by this figure the slmans were enclofed, and cur in peeces.

The Rhombus or Lozenge figure fo vifible in this order, was alfo a remarkable form of battle in the Grecian C Cavalry, e Iliaso obferved by the Theffelians, and Philip Tat. King of Macedon, and frequently by the Partbisns, As being moft ready to turn every way, and beft to be commanded, as having its ductors, or Commanders at each Angle.

The CAacedonian Pbalanx (a long time thought invincible) confifted of a long I2 fquare.

- Agatbins Antrianuso 


\section{$116 \quad$ Cyrms-Garden, Or}

fquare. For though they might be fixteen in Rank and file, yet when they fhut clore, fo that the fixt pike advanced before the firt, though the number might be fquare, the figure was oblong. anfwerable unto the Quincunciall quadrate of Curtius. According to this fquare Thucydides delivers, the Atherians difpofed their battle againft the Lacedemoni$f$ sy $\pi$ rau- ans f brickwife, and by the fame word óต.

s Secto via limite qua. dret. Comment. in Virgil. the Learned Guellius expoindeth the quadrate of $\mathrm{g}$ Virgil, after the form of a brick or tile.

And as the firft ftation and pofition of trees, fo was the firft habitation of men, not in round Cities, as of later foundation ; For the form of Babylos the firtt City was fquare, and fo thall alfo be the laft, according to the defcription of the holy City in the Apocalyps. The famons pillars of seth before the floud, had alfo the like foundation, if they were but antidiluvian Obelisks, and fuch as cham and his Egyptian race, imitated after the Floud.

But Ninereb which Authours acknowledge to have exceeded Babylon, was of Diod. Sic. a h longilaterall figure, ninety five Furlongs 


\section{The Quincunx Artificially'Confidered 117}

longs broad, and an hundred and fifty long, and fo making about fixty miles in circuit, which is the meafure of three dayes journey, according unto military marches, or caftrenfiall manfions. So that if fones entred at the narrower fide, he found enough for one dayes walk t. attain the heart of the City, to make his Proclamation. And if we imagine a Ciry extending ?rom Wayt to London, the expreffion will be moderate of fix fcore thoufand Infants, although we allow vacuities, fields, and intervals of habitaticn as there nceds inuft be when the monuinent of Nisus tock up no leffe then ten fur!nngs.

$A_{1}, d$, though none of the feven wonders, yet a noble peere of Antiquity, and made by a Copy exceeding all the reft, had its principall parts difpofed after this manner, that is, the Labyrinth of Crete, built upon a long quadrate, containing five large fquares, communicaring by right inflections, terminating in the centre of the middle fquare, and lodging of the Minotalur, if we conform unto the i Antonio defcription of the elegant medall thereof in $i$ Aroftino, And though in many acdollen edag. li?.

$$
I_{3} \text { counts }
$$


counts we reckon grolly by the fquare, yet is that very often to be accepted as a long fided quadrate, which was the figure of the Ark of the Covenant, the table of the Shew-bread, and the Ptone wherein the names of the twelve Tribes were engraved, that is, three in a row, naturally making a longilaterall Figure, the perfect quadrate being made by Dine.

What figure the Atones themfelves maintained, tradition and Scripture are filent, yet Lapidaries in precious ftones affect a Table or long fquare, and in fuch proportion, that the two laterall, and alfo the three inferiour Tables are equall unto the fuperiour, and the angles of the laterall Tables, contain and conftitute the byporbenufa, or broader fides fubtending.

That the Tables of the Law were of this figure, general imitation and tradition hath confirmed; yet are we unwilJing to load the foulders of Mofes with fuch maflie ftones, as fome pictures lay upon them, fince 'tis plainly delivered that he came down with them in his band; fince the word Atrictly taken im- 
The QuincunxArtificially Confidered II

plies no fuch maffie hewing, but cutting, and fafhioning of them into thape and furface; fince fome will have them $\mathrm{E}$ meralds, and if they were made of the materials of Mount Sina, not improbable that they were marble: Since the words were not many, the letters fhort of five hundred, and the Tables written on both fides required no fuch capacity.

The beds of the Ancients were different from ours at prefent, which are almoft fquare, being framed ob-long, and about a double unto their breadth; not much unlike the area, or bed of this Quincuncial quadrate. The fingle beds of greece were a fix foot, and a little more a Arifoo, in length, three in breadth; the Giant- Mechan. like bed of $O g$, which had four cubits of bredth, nine and a half in length, varied not much from this proportion. The Funeral bed of King Cbeops, in the greater Pyramid, which holds feven in length, and four foot in bredth, had no great difformity from this meafure; And what foever were the bredth, the length could hardly be leffe, of the tyrannical bed of Procruffes, fince in a fhorter meafure he had not been fitted with perfons for his

$$
\text { I } 4 \text { crueliy }
$$



\& Plat, in chral oed, or Amazonian $k$ Tomb in the vit, Ihef. markot-place of Megara, wasin the form of a Lozenge; readily made out by the compolure of the body. For the arms not lying fafciated or wrapt up after the Greciose manner, but in a middle diftention, the ancluding limes will ftrictly make out that figure, 


\section{CHA P. III.}

NOw although this elegant ordinaI tion of vegetables, hath found coincidence or imiration in fundry works of Art, yet is it not alfo deftitute of naturall examples, and though overlookeci by all, was elegantly obfervable, in feverall works of nature.

Could we fatisfie our felves in the pofition of the lights above, or difcover the wifedom of that order fo invariably maintained in the fixed Stars of heaven; Could we have any light, why the ftellary part of the firft maffe, feparated into this order, that the Girdle of Orion thould ever maintain its line, and the two Starres in Charles's Wain never leave pointing at the Pole-Starre, we might abate the Pythagoricall Mufick of the Spheres, the fevenfold Pipe of Panz and the ftrange Cryptography of Gaffarell in his Starrie Booke of Heaven. 
But not to look fo high as Heaven or the fingle Quincunx of the Hyades upon the neck of Tawrus, the Triangle, and remarkable Crufero about the foot of the Centaur; obfervable rudiments there are hereof in fubterraneous concretions, and borlies in the Earth; in the Gypfum or 1 inm Rhomboides, in the Favaginites or honey-comb-ftone, in the Afleria and Astroites, and in the crucigerous ftone of S. lago of gallicia.

The fame is obfervably effected in the Fulus, Cutkins, or pendulous excrefcencies of feverall Trees, of Wall-

Capitula

Copenussate

Rerceren

Buabini, whereof though he Gith pervaro reperiunmor bistan. mom invenimex. yet we finde thein com. monly with ns and in ereat num. bers. nuts, Alders, and Hazels, which hanging all the Winter, and maintaining their Net-worke clole, by the expan: fion thereof are the early foretellers of the Spring, difcoverable alfo in long Pepper, and elegantly in the falms of Calamus Aromaticus, fo plentifully growing with us in the firtt palmes of Willowes, and in the Flowers of Sycamore, Petafites, Afphodelus, and Blatiaris, before explication. After fuch order ftand the Howery Branches in our beft fpread 
The Quincunx Naturally Confidered.

Spread Verbascum, and the feeds about the fpicous head or torch of Tapfas Barbatus, in as fair a regularity 28 the circular and wreathed order will admit, which advanceth one fide of the fquare, and makes the fame Rhomboidall.

In the fquamous heads of Scabious, Knappoeed, and the elegant Facea Pinea, and in the Scaly compolure of the OakRofe, which fome years moft aboundeth. After this order hath Nature planted the Leaves in the Head of the common and prickled Artichoak; wherein the black and thining Flies do Thelter themfelves, when they retire from the purple Flower about it; The fame is alfo found in the pricks, fockets, and impreffions of the feeds, in the pulp or bottome thereof; wherein do elegantly ftick the Fathers of their Mother. To omit the Quincunciall Specks on the top of the Mifcle-berry, efpecially that which grows upon the Tilia or Lime-Tree. And the remarkable difpofure of thofe yellow fringes about the purple Peftill of Aaron, and elegant clufters of Dragons, fo peculiarly fecured by nature, with

Antbo.Grac inter Epi. grammale vespaidn

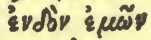

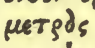
rayioas Ex $x$ करी? 


\section{Cyrus-Garden, Or}

an unibrella or skreening Leef about them.

The Spongy leaves of fome Sea. expecially wracks, Fucus, Oaks, in their feverall the porks croviturs Imperati, sporota, or Alga $\pi$ तa Tirespos. Deubini.

kindes, found about the Shoar, with ejectments of the Sea, are over-wroughe with Net-work elegantly containing this order, which plainly declareth the naturality of this texture; And how the needle of mature deligbteth to work, even in low and doubt ful vegetations.

The Arbustetwre or Thicket on the head of the Tearell, may be obferved in this order: And he that confidereth that fabrick fo regularly palifadoed, and ftemm'd with Howers of the royall colour; in the houfe of the folitary maggot, may finde the Seraglio of Solomon, And contemplating the calicular fhafts, and uncous difpolure of their extremities, fo accommodable unto the office of abfterfion, not condemne as wholly improbable the conceit of thofe who ac- Ier, 2,22. cept it, for the herbe d Boritb. Where by the way, we could with much inquiry never difcover any tranffiguration, in this abftemious infect, although we 
The QuincrunxNaturally Confidered. 125

have kept them long in their proper houles, and boxes Where fome wrapt up in their webbs, have lived upon their. own bowels, from September unto July.

In fuch a grove doe walke the little creepers about the head of the burre. And fuch an order is oblerved in the aculeous prickly plantation, upon the beads of feveral common thifles, remarkably in the notable palifados about the flower of the milk. Thiftle; and he that inquireth into the little bottome of the globe-thiftlc, may finde, that gallant bufh arife from a fcalpe of like dilpofure.

The white umbrella or medicall bulh of Elder, is an Epirome of this order : 2rifing from five main fremms Quincuncially difpofed, and tollerably maintained in their fubdivifions. To omit the lower obfervations in the feminal fpike of Mercurie weld, and Plantane.

Thus hath nature ranged the flowers of Santfoyne, and French honey fuckle; and fomewhat after this manner hath ordered the bufh in Fupiters beard, ot houfe- 


\section{6 \\ Cyrus-Garden, Or}

boufeleek; which old fuperftition fet on the tops of houfes, as a defenfative againft lightening, and thunder. The like in Fenny Seagreen or the water Astrutioess. "Souldier; which, though a militarie name from Greece, makes out the Roman order.

A like ordination there is in the favaginous Sockets, and Lozenge feeds of the noble flower of the Sunne. Wherein in Lozenge figured boxes nature thuts up the feeds, and balfame which is about them,

But the Firre and Pinetree from their fruits doe naturally dictate this pofition. The Rhomboidall protuberances in Pineapples maintaining this Quinouncial order unto each other, and each Rhombus in it felfe. Thus are alfo difpofed the triangular foliations, in the conicall fruit of the firre tree, orderly thadowing and protecting the winged feeds below them.

The like fo often occurreth to the curiofity of obfervers, efpecially in fpicated feeds and flowers; that we fhall not need to take in the fingle Quincunx of Fuchfi- 
The Quincunx Naturally Confidered, 127 us in the grouth of the malle fearn, the feedie difpofure of Gramen Ifchemon, and the trunk or neat Reticulate work in the codde of the Sachell palme.

For even in very many round thalk plants, the leaves are fet after a Quintuple ordination, the firft leaf anfwering the fitth, in lateral difpofition. Wherein the leaves fucceflively rounding the ftalke, in foure at the furtheft the compals is abfolved, and the fifth leafe or Sprout, returns to the polition of the other fift before it; as in accounting upward is often obfervable in in furre pellitorye, Ragweed, the fproutes of Oaks, and thorns upon pollards, and very remarkably in the regular difpofure of the rugged excrefcencies in the yearly thoots of the Pine.

But in fquare ftalked plants, the leaves ftand refpectively unto each other, either in crofle or decuffation to thofe above or below them, arifing at croffe pofitions; whereby they thadow not each other, and bettter refift the force of winds, which in a parallel fituation, and upon fquare ftalkes would more forcibly 


\section{Cyrus-Garden, Or}

forcibly bear upon them.

And to omit, how leaves and fprouts. which compaffe not the ftalk, are often fet in a Rhomboides, and making long; and (hort Diagonals, doe ftand like the leggs of Quadrupeds when they goe : Nor to urge the thwart enclofure and furdling of flowers, and bloffomes, before explication, as in the multiplyed leaves of Pionie; And the Chiafmus in five leaved flowers, while one lies wrapt about the ftaminous beards, the other foure obliquely thutting and clofing upon each other; and how even flow: er's which confift of foure leaves, ftand not ordinarily in three and one, but two, and two croffewife unto the Stylus; even the Autumnal budds, which awante the returne of the fun, doe after the winter folftice multiply their calicular leaves, making little Rbombufes, and network figures, as in the Sycamore and $\mathrm{Li}_{-}$ lac.

The like is difcoverable in the original production of plants, which firt putting forth two leaves, thofe which fucceed, bear not over each other, but 


\section{The Quincunx Naturally Confidered. 129}

thoot obliquely or croffewife, untill the Italke appeareth; which fendeth nor forth its firft leaves without all order unto them; and he that from hence can diffeover in what pofition the two firft leaves did arife, is no ordinary obfervator.

Where by the way, he that oblerveth the rudimental fpring of feeds, thall finde ftrict rule, although not after this order. How little is required unto effectual generation, and in what diminutives the plaftick principle lodgeth, is exemplified in feeds, wherein the greater mafs affords fo little comproduction. In Beanes the leaf and root fprout from the Germen, the main fides fplit, and lye by, and in fome pull'd up near the rime of blooming we have found the pulpous fides intire or little wafted. In Acorns the nebb dilating fplitteth the two fides, which fometimes lye whole, when the Oak is fprouted two handfuls. In Lupins thefe pulpy fides do fometimes arife with the ftalk in a refemblance of two fat leaves. Wheat and Rye will grow up, if after they have K 
thot fome tender Roots, the adhering pulp be taken from them. Beanes will profper though a part be cut away, and fo much fet as fufficeth to contain and keep the German clofe. From this fupertluous pulp in unkindely, and wet years, may arife that multiplicity of little infects, which infeft the Roots and Sprouts of tender Graines and pulfes.

In the little nebbe or fructifying principle, the motion is regular, and not tranfvertible, as to make that ever the leaf, which nature intendeth the root; obfervable from their converfion, until they attain their right pofition, if feeds be fet inverfedly.

In vain we expect the production of plants from different parts of the feed, from the fame corculum or little original proceed both germinations; and in the power of this flender particle lye many Roots, that though the fame be pull'd away, the generative particle will renew them again, and proceed to a perfect plant ; And malt may be obferved to grow, though the Cummes be fallen from it. 
The Quincunx Naturally Confidered. I/I

The feminall nebbe hath a defined and fingle place, and not extended unto both extremes. And therefore many too vulgarly conceive that Barley and Oats grow at both ends; For they arife from one pancitilio or generative nebbe, and the Speare Miding under the husk, firft appeareth nigh the toppe. But in Wheat and Rye being bare the prouts are feen togerher. If Barley unhulled would grow, both would appear at once. Bur in this and Oat-meal the nebbe is broken away, which makes them the milder food, and leffe apt to raife fermentation in Decoctions.

Men taking notice of what is outwardly vifible, conceive a fenfible priority in the Root. But as they begin from one part, fo they feem to ftart and fet. out upon one fignall of nature. In Beans yet foft, in Peafe while they adhere unto the Cod, the rudimentall Leafe and Root are difcoverable. In the Seeds of Rocket and Muftard, Sprouting in Glaffes of water, when the one is manifeft the other is alfo peeceptible. In

$$
\mathrm{K}_{2} \text { muddy }
$$


muddy waters apt to breed Dwckweed, and Periwinkles, if the firft and rudimentall ftroaks of Duckweed be obferved, the Leaves and Root anticipate not each other. But in the Date-ftone the firft fprout is neither root nor leaf diftinctly, but borh together; For the Germination being to paffe through the the narrow Navell and hole about the midft of the ftone, the generative germ is faine to enlengthen it felf, and hooting out about an inch, at that diftance divideth into the afcending and defcending portion.

And though it be generally thought that Seeds will root at that end, where they adhere to their Originals, and obfervable it is that the nebbe fets moft often next the ftalk, as in Grains, Pulfes, and moft frnall Seeds, yet is is hardly made out in many greater plants. For in Acornes, Almonds, Piftachios, Wallnuts, and accuminated thells, the germ pnts forth at the remoteft part of the pulp. And therefore to fet Seeds in that pofture, wherein the Leaf and Roots may thoot right without contortion, 
The Quincunx Naturally Confidered 133 tion, or forced circumvolution, which might render them ftrongly rooted, and ftraighter, were a Criticifme in Agriculture. And nature feems to have made fome provifion bereof in many from their figure, that as they fall from the tree they may lye in Pofitions agreeable to fuch advantages.

Befide the open and vifible Tefticles of plants, the feminall pores lie ingreat part invifible, while the Sun findes polypody in ftone-wals, the little ftinging Nettle, and nighthade in barren fandy High-wayes, Scurvy-grafe in Greeneland, and unknown plants in earth broughe from remote Countries, Befide the known longevity of fome Trees, what is the moft lafting herb, or feed, feems not eafily determinable. Mandrakes upon known account have lived near an hundred yeares. Seeds found in Wilde-Fowls Gizards have fprouted in the earth. The Seeds of Marjorane and Stramonium carelefly kept, have grown after feven years. Even in Garden-plots long fallow, and digged up, the feeds of Blattaris and yellow henbane,and after

K 3 twelve 


\section{4 Cyrus-Garden, Or}

twelve years burial have produced themfelves again.

That bodies are firft fpirits $P$ aracelfus could affirm, whicn in the maturation of Seeds and fruits, feems obfcurely - In met. implied by a caristotle, when he deliam Gabee. vereth, that the firituous parts are converted into water, and the water into earth, and attefted by obfervation in the maturative progreffe of Seeds, wherein at firft may be difcerned a Hlatuous diftenfion of the husk, afterwards a thin liquor, which longer time digefteth into 2 pulp or kernell obfervable in $\mathrm{Al}$ monds and large Nuts. And fome way anfwered in the progreffionall perfealon of animall femination, in its fpermaticall maturation, from crude pubefcency unto perfection. And even that feeds themielves in their rudimentall difcoveries, appear in foliaceous furcles, or Sprouts within their coverings, in a diaphonous gellie, before deeper incr-ffation, is alfo vifibly verified in Cherries, Acorns, Plums.

From feminall confiderations, either in reference unto one mother, or diftin- 


\section{The Quincunx Naturally Confidered.}

Cion from animall production, the holy Scripture defcribeth the vegetable creation; And while it divideth plants but into Herb and Tree, though it feemeth to make but an accidental divifion, from magnitude, it tacitely containeth the naturall diftinction of vegetables, ob. ferved by Herbarifts, and comprehending the four kinds. For fince the moft naturall diftinction is made from the production of leaf or ftalk, and plants after the two firft feminall leaves, do either proceeed to fend forth more leaves, or a ftalk, and the folious and ftalky emiffion diftinguifheth herbs and trees, and Itand Authentically differenced, but from the accidents of the ftalk.

The Equivocall production of things under undifcerned principles, makes a large part of generation, though they feem to hold a wide univocacy in their fet and certain Originals, while almoft every plant breeds its peculiar infect, moft a Butcerfly, moth or fly, wherein the Oak feems to contain the largeft feminality, while the Julus, Oak, apple, dill, woolly tuft, foraminous roundles

$$
\mathrm{K}_{4}
$$

upon 


\section{Cyrus-Garden, Or}

upon the leaf, and grapes under ground make a Fly with fome difference.

The great variety of Flyes lyes in the variety of their originals, in the feeds of $\mathrm{Ca}_{2-}$ terpillars or Cankers there lyeth not onIy a Butterfly or Moth, but if they be fterill or untimely caft, their production is often a Fly, which we have allo obferved from corrupted and mouldred Egges, both of Hens and Fifhes; To omit the generation of Bees out of the bodies of dead Heifers, or what is

scbone. frrange yet well attefted, the production celdere de Pife. of Eeles in the backs of living Cods and Perches.

The exiguity and fmallneffe of fome feeds extending to large productions is one of the magnalities of nature, fome. what illuftrating the work of the Crea tion, and vaft production from notbing $\Sigma$ Dodiffim. The true a feeds of Cyprefle and Ram. Laurenburs horre

pions are indiftinguifhable by old eyes Of the feeds of Tobacco a thoufanc make not one grain, Tha difputed feed: of Harts tongue, and Maidennair, tequire a greater number. From fuch un difoernable leminalities arife fpontaneou: 
The Quincunx Naturally Confidered.

productions. He that would difeern the rudimentall ftroak of a plant, may behoid it in the Originall of Duckweed, at the bigneffe of a pins point, from convenient water in glaffes, wherein a watchfull eye may alfo difcover the puncticular Originals of Periwincles and

Gnats.

That feeds of fome Plants are leffe then any animals, feems of no clear decifion; That the biggeft of Vegetables exceedeth the biggeft of Animals, in full bulk, and all dimenfions, admitsexception in the Whale, which in length and above ground meafure, will allo conrend with tall Oakes. That the richeft odour of plants, furpaffeth that of Animals may feem of fome doubt, fince animall-musk, feems to excell the vegetable, and we finde fo noble a fcent in the Tulip-Fly, and b Goat-Beetle.

Now whether feminall nebbes hold any fure proportion unto feminall enclofures, why the form of the germe doth not anfwer the figure of the enclofing pulp, why the nebbe is feated upon b The long and tender green $\mathrm{Ca}_{-}$ pricernus rarely found, we could never meet with but two. the folid, and not the channeld fide of 
the feed 25 in grains, why fince we often meet with two yolks in one fhell, and fometimes one Egge within another, we do not oftener meet with two nebbes in one diftinct feed : why fince the Egges of a Hen laid at one courfe, do commonly out-weigh the bird, and fome moths coming out of their cafes, without affiftance of food, will lay fo many Egges as to our-weigh their bodies, trees rarely bear their fruit, in that gravity or proportion: Whether in the germination of feeds according to Hippocrates, the lighter part afcendeth, and maketh the fprout, the heavieft tending downward frameth the root; Since we obferve that the firft fhoot of feeds in water, will fink or bow down at the upper and leafing end: Whether it be not more rational Epicurifme to contrive whole difhes out of the nebbes and fpirited particles of plants, then from the Gallarures and treddles of Egges; fince that part is found to hold no feminal thare in Oval Generation, are quaries which might enlarge but muft conclude this digreffion. 


\section{The Quincunx Naturally Confidered, 139}

And though not in this order, yet how nature delighteth in this number, and what confent and coordination there is in the leaves and parts of flowers, it cannot efeape our obfervation in no fmall number of plants. For the calicular or fupporting and dofing leaves, do anfwer the number of the flowers, efpecially in fuch as exceed not the number of Swallows Fgges; as in Violets, Stichwort, bloffomes, and flowers of one leaf have often five divifions, anfwered by a like number of calicular leaves; as Gentianella, Convolvulus, Bellflowers. In many the flowers, blades, or ftaminous thootes and leaves are all equally five, as in cockle, mullein and Blattaria; Wherein the flowers before explication are pentagonally wrapped up, with fome refemblance of the blatte or moth from whence it hath its name: But the contrivance of nature is fingular in the opening and fhutting of Bindeweeds, performed by five inflexures,diftinguifhable by pyramidcall figures, and alfo different colours.

The rofe at firft is thought to have been 
been of five leaves, as it yet groweth wilde among us; but in the molt luxuriant, the calicular leaves do ftill maintain that number. But nothing is more admired then the five Brethren of the Rofe, and the ftrange difpofure of the Appendices or Beards, in the calicular leaves thereof, which in defpair of refolution is tolerably falved from this contrivance, beft ordered and fuited for the free clofure of them before explication. For thofe two which ase fmooth, and of no beard are contrived to lye undermoft, as without prominent parts, and fit to be fmoothly covered; the other two which are befet with Beards on either fide, ftand outward and uncovered, but the fifth or half-bearded leaf is covered on the bare fide but on the open fide ftands free, and bearded like the other.

Befides a large number of leaves have five divifions, and may be circumferibed by a Pentagen or figure of five $\mathrm{An}$ gles, made by right lines from the extremity of their leaves, as in Maple, Vine, Figge-Tree : But five-leaved 


\section{The QuincurxNaturally Confidered. I41}

flowers are commonly difpofed circularly about the Stylass; according to the higher Geometry of nature, dividing a eircle by five radii, which concurte not to make Diameters, as in Quadrilaterall and fexangular Interfections.

Now the number of five is remarkable in every circle, not only as the firft fphxrical number, but the meafure of fphxrical motion. For fphxerical bodies move by fives, and every globular figure placed upon a plane, in direct volutation, returns to the firft point of contaQtion in the firft touch, accounting by the Axes of the Diameters or Cardinall points of the four quarters thereof. And before it arriveth unto the fame point again, it maketh five circles equall unto it felf, in each progreffe from thofe quarters, abfolving an equall circle.

By the fame number doth nature divide the circle of the Sea-Starre, and in that order and number difpofeth thofe elegant Semi-circles, or dentall fockets and egges in the Sea Hodgehogge. And no mean Obfervations hereof 
hereof there is in the Mathematicks of the neateft Retiary Spider, which concluding in fourty four Circles, from five Semidiameters beginneth that elegant texture.

And after this manner doth lay the foundation of the circular branches of the Oak, which being five-cornered, in the tender annual fprouts, and manifefting upon incifion the fignature of a Starre, is after made circular, and fwel'd into a round body: Which praElem.li.4. Citce of nature is become a point of art, and makes two Problemes in Euclide. But the Bryar which fends furth thoots and prickles from its angles, maintains itt pentagonall figure, and the unobferved fignature of a handfome porch withinit. To omit the five fmall buttons dividing the Circle of the Ivy-berry, and the five characters in the Winter fralk of the Walnut, with many Other Obfervables, which cannot efcape the eyes of fignal difoerners; Such as know where to finde cljax his name in Gallitricum, or Aajons Mitre in Henbane. 


\section{The Quincunx Naturally Confidered. 143}

Quincuncial forms and ordinations,are alfo obfervable in animal figurations. For to omit the hioides or throat-bone of animals; the furcula or merry-thought in birds, which fupporteth the capule, affording a paffage for the windepipe and the gullet, the wings of Flyes, and difpolure of their legges in their firft formation from maggots and the pofition of their horns, wings and legges, in their Aurelian cafes and fwadling clouts : The back of the Cimex Arborews, found often upon Trees and leffer plants, doth elegantly difcover the Burgundian decuffation; And the like is obfervable in the belly of the Notonecton, or water-Beetle, which fwimmeth on its back, and the handfome Rhombuffes of the Seapoult, or Werrell, on either fide the Spine.

The fexangular Cels in the Honeycombs of Bees, are difpofed after this order, much there is not of wonder in the confufed Houfes of Pifmires, though much in their bufie life and actions, more in the edificial Palaces of Bees and Monarchical fpirits; who make their combs 
combs fix-corner'd, declining a circle, whereof many ftand not clofe together, and compleatly fill the area of the place; But rather affecting a fix-fided figure, whereby every cell affords a common fide unto fix more, and alfo a fit receptacle for the Bee it felf, which gathering into a Cylindrical Figure, aptly enters its fexangular houfe, more nearly approaching a circular Figure, then either doth the Square or Triangle. And the Combes themfelves fo regularly contrived, that their murual interfections make three Lozenges at the bottome of every Cell; which feverally regarded make three Rows of neat Rhomboidall Figures, connected at the angles, and fo continue three feveral chains throughout the whole comb.

As for the Favago found commonly on the 8ea thoar, though named from an honey-comb, it but rudely makes out the refemblance, and better agrees with the round Cels of humble Bees. He that would exactly difcern the thop of a Bees mouth, need oblerving eyes, and good augmenting glaffes; wherein is 
The Quincunx Naturally Confidered. I 45

difcoverable one of the neateft peeces in nature, and muft have a more piercing eye then mine; who findes out the thape of Buls heads, in the guis of Drones preffed out behinde, according to the experiment of Gomefows; wherein notwithftanding there feemeth fomeGom. ds what which might incline a pliant fancy to credulity of fimilitude.

A refemblancehereof there is in the orderly and rarely difpored Cels, made by Flyes and Infects, which we have often found faftened about fmall fprigs, and in thofe cottonary and woolly pillows, which fometimes we meet with faftened unto Leaves, there is included an elegant Net-work Texture, out of which come many fmall Flies. And fome refemblance there is of this order in the Egges of fome Butterflies and moths, as they frick upon leaves, and other fubftances; which being dropped from behinde, nor directed by the eye, doth neatly declare how nature Geometrizeth, and obferveth order in all things,

A like correfpondency in figure is L found 
found in the skins and outward teguments of animals, whereof a regardable part are beautiful by this texture. As the backs of feveral Snakes and Serpents, elegantly remarkable in the Apis, and the Dart-fnake, in the Chiafmus and larger decuffations upon the back of the Rattlefnake, and in the clofe and finer texture of the Mater formicarum, or fnake that delights in Anthils; whereby upon approach of outward injuries, they can raife a thicker Phalanx on their backs, and handfomely contrive themfelves into all kindes of Hexures : Whereas their bellies are commonly covered with fmooth femicircular divifions, as beft accommodable unto their quick and gliding motion.

This way is followed by nature in the peculiar and remarkable tayl of the Bever, wherein the fcaly particles are difpofed, fomewhat after this order, which is the plaineft refolution of the wonder of Bellonius, while he faith, with incrediblc Artifice hath Nature tramed the tayl or Oar of the Bever: where by the 
The Quincunx Naturally Confidered.

way we cannot but with a model of their houfes, fo much extolled by fome Defcribers: wherein fince they are fo bold as to venture upen three ftages, we might examine their Artifice in the coutignations, the rule and order in the compartitions; or whether that magnified ftructure be any more then a rude rectangular pyle or meer hovell-building.

Thus works the hand of nature in the feathery plantation about birds, Obfervable in the skins of the ${ }^{*}$ breaft, legs and Pinions of Turkies, Geefe, and Ducks, and the Oars or finny feet of * Elegantly confícuous on the infide of Water-Fowl: And fuch a naturall Net the fripis the fcaly covering of Fifhes, of Mul- ped skins lets, Carps, Tenches, $6 c^{c}$. even in fuch as are excoriable and confift of fmaller feales, as Bretts, Soals, and Flounders. The like Reticulate grain is obfervable in fome Ruffas Leather. To omit the Fowl, of theCormorant,Gorhonder, Wearell, Loonatic. ruder Figures of the oftracion, the triangular or cunny fifh, or the pricks of the Sea:Porcupine.

The fame is alfo obfervable in fome part of the skin of man, in habits of neat $L_{2}$ tex. 
texfure, and therefore not unapily compared unto a Net: We tball not affirm that from fuch grounds, the Egyptian Embalmers imitated this texture yet in their linnen folds the fame is ftill obfervable among their neateft Mummies, in the figures of $I /$ is and O/gris, and the Tutelary fpirits in the Bembine Table. Nor is it to be over-looked how Orus, the Hieroglyphick of the world is defcribed in a Net-work covering, from the thoulder to the foot. And (not to enlarge upon the cruciated character of Trismegiflus, or handed croffes, fo often occurring in the Needles of $P$ baraob, and Obelisks of Antiquity) the Statuce Ifoice, Teraphims, and little Idols, found about the Mummies, do make a decuffation or Facubs Croffe, with their armes, like that on the head of $E$ phraim and Ganafjes, and this decuffis is alfo graphically defcribed between them.

This Reticulate or Net-work was alfo confiderable in the inward parts of man, not only from the firt subtegmen or warp of his formation, bot in the netty 
The Quincunx Naturally Confidered

filves of the veins and veffels of life; wherein according to common Anatomy the right and tranfverfe fibres are decuffated, by the oblique fibres; and fo muft frame a Reticulate and Quincunciall Figure by their Obliquations, Emphatically extending that Elegant expreffion of Scripture. Thou haft curiounly embroydered me, thou halt wrought me up after the fineft way of texture, and as it were with a Needle.

Nor is the fame obfervable only in fome parts, but in the whole body of man, which upon the extenfion of arms and legges, doth make out a fquare, whofe interfection is at the genitals. To omit the phantaftical Quincunx, in Plato of the firft Hermaphrodite or double man, united at the Loynes, which Fupiter after divided.

A rudimentall refemblance hereof there is in the cruciated and rugged folds of the Reticulum, or Net-like Ventricle of ruminating horned animals, which is the fecond in order, and culinarily called the Honey-comb. For many di

$$
L_{3} \text { vifions }
$$


vilions there are in the ftomack of feverall animals; what number they maintain in the scarus nnd ruminating Fifh, cominon defcription, or our own experiment hath made no difcovery. But in the Vertricle of Porpufes there are three divifions. In many Birds a crop, Gizard, and little receptacle before it; but in Cornigerous anjmals, which chew the cudd, there are no lefs then four of diftinct pofition and office.

The Reticulam by thefe croffed cels, makes a further digeftion, in the dry and exuccous part of the Aliment received from the firft Ventricle. For at the bottome of the gullet there is a double Orifice; What is firft received at the mouth defcendeth into the firft and greater ftomack, from whence it is re turned into the mouth again; and after a fuller maftication, and falivous mixture, what part thereof defcendeth again, in a moift and fucculent body, it nides down the fofter and more permeable Orifice, into the Omafus or third ftomack; and from thence conveyed 


\section{The Quincunx Naturally Confidered. I5 I}

into the fourth, receives its laft digeftion. The other dry and exuccous part after rumination by the larger and ftronger orifice beareth into the firft ftomack, from thence into the Reticulum, and fo progreffively into the other divifions. And therefore in Calves newly calved, there is little or no ufe of the two firft Ventricles, for the milk and liquid aliment flippeth down the fofter Orifice, into the third ftomack; where making little or no ftay, it paffeth into the fourth, the feat of the cougulmm, or Runnet, or that divifion of ftomack which feems to bear the name of the whole, in the Greek tranllation of the Priefts Fee, in the Sacrifice of Peace-offerings.

As for thofe Rhomboidal Figures made by the Cartilagineous parts of the Wezon, in the Lungs of great Fifhes, and other animals, as Rondeletius difcovered, we have not found them fo to anfiver our figure as to be drawn into illuftration; Something we expected in the more difcernable texture of the lungs of frogs, which notwithftanding being

$$
\text { L } 4
$$

but 
but two curious bladders not weighing above a grain, we found interwoven with veins not obferving any juft order. More orderly fituated are thofe cretaceous and chalky concretions found fometimes in the bigneffe of a fmall fech on either fide their fpine; which being not agreeable unto our order, nor yet obferved by any, we thall not here difcourfe on.

But bad we found a better account and tolerable Anatomy, of that promi2 issa. de- nent jowle of the a sperma Geti Whale, fcribed in then queftuary operation, or the ftench
our $r$ feudo. Epidem. Edit.3. of the laft caft upon our thoar, permitted, we might have perhaps difcovered fome handfome order in thafe Net-like feares and fockets, made like honey-combs, containing that medicall matter.

Laftly, The inceffion or locall motion of animals is made with analogy unto this figure, by decuffative diametrals, Quincunciail $L$ ines and angles. For to omit the enquiry how Buttertlies and breezes mave their four wings, how birds and fithes in ayre and water move 
The Quincunx Naturally Confidered.

by joynt ftroaks of oppofite wings and Finnes, and how falient animals in jumping forward feem to arife and fall upon a fquare bafe; As the ftation of molt Quadrupeds, is made upon a long fquare, fo in their motion they make a Rhomboides; their common progreffion being performed Diametrally, by decuffation and croffe advancement of their legges, which not obferved begot that remarkable abfurdity in the pofition of the legges of caffors horfe in the Capitol. The Snake which moveth circularly makes his fpires in like order, the convex and concave fpirals an wering each other at alternate diftances; In the motion of man the armes and legges obferve this thwarting pofition, but the legges alone do move Quincuncially by fingle angles with fome refemblance of an $\mathbf{V}$ meafured by fucceffive advancement from each foot, and the angle of indenture great or leffe, according to the extent or brevity of the ftride.

Studious Obfervators may difcover more analogies in the orderly book of

pature, 


\section{Cyrus-Garden, Or}

nature, and cannot efcape the Elegancy of her hand in other correfpondencies. The Figures of nails and crucifying appurtenances, are but precarioully made out in the Graradilla or flower of Chrifts paffion: And we defpair to behold in thefe parts that handfome draught of crucifixion in the fruit of the Barbado Pine. The feminal Spike of $P$ balaris, or great thaking graffe, more nearly anfwers the tayl of a Rattle-Snake, then many refemblances in Porta: And if the - Orchis An- man b Orcbis of Columna be well made etbropopbora, Fabii Co.

Inomine. out, it excelleth all analogies. In young Wallnuts cut athwart, it is not hard to apprehend Atrange characters; and in thofe of fomewhat elder growth, handfome ornamental draughts about a plain crofle. In the root of ofmosed or Water fern, every eye may difcern the form of a Half Moon, Rain-bow, or half the character of Pifces. Some finde Hebrew, A rabick, Greek, and Latine Characters in Plants; In a common one among us we feem to reade Acaia, Vivik, Lilil.

Right lines and circles make out the bulk 
The Quincunx Naturally Confidered. 155

bulk of plants; In the parts thereof we finde Helicall or fpirall roundles, voluta's, conicall Sections, circular Pyramids, and fruftums of Arcbimedes; And cannot overlook the orderly hand of nature, in the alternate fucceffion of the flat and narrower fides in the tender Thoots of the Afhe, or the regular inequality of bigneffe in the five-leaved flowers of Henbane, and fomething like in the calicular leaves of Twt fon. How the fpots of Perficaria do manifeft themfelves between the fixt and tenth ribbe. How the triangular capp in the ftemme or fylus of Tuleps doth conftantly point at three outward leaves. That fpicated flowers do open firtt at the ftalk. That white flowers have yellow thrums or knops. That the nebbe of Beans and Peafe do all look downward, and fo preffe not upon each other; And how the feeds of many pappous or downy flowers lockt up in fockets after a gomphofis or mortis-articulation, diffufe themfelves circularly into branches of rare order, obfervable in Tragopogon or Goats-beard,conformable to the Spiders web, 


\section{Cyrus-Garden, Or}

ureb, and the Radii in like manner teiarely inter-woven.

And how in animall natures, cven colours bold correfpondencies, and mutuall correlations. That the colour of the Carerpillar will thew again in the Butterfly, with fome latitude is allowable. Though the regular fpots in their wings feem but a mealie adhefion, and fuch as may be wiped away, yet fince they come in this variety, out of their cafes, there muft be regular pures in thofe parts and membranes, defining fuch Exudations.

- Suet. in vit, Axg.

That $b$ Anguftus had native notes on his body and belly, afrer the order and number in the Starre of Charles wayne, will rot feem ftrange unto aftral Phyfiognomy, which accordingl y coniidereth moles in the body of man, or Phyficall Obfervators, who from the pofition of moles in the face, reduce them to rule and correfpondency in other parts. Whether after the like method medicall conjecture may not be raifed, upon parts inwardly affected; fince parts about the lips are the critical feats of Puftules difcharged 


\section{The QuincunxNaturally Confidered. 157}

charged in Agues; And fcrophulous tumours about the neck do fo often Ipeak the like about the Mefentery, may alfo be confidered.

The ruffet neck in young Lambs feems but adventitious, and may owe its tincture to fome contaction in the womb; But that if Theep have any black or deep ruffet in their faces, they want not the fame about their legges and feet; That black Hounds have mealy mouths an. feet; That black Cows which have ar. $f$ white in their tayls, fhould not miffe of fome in their bellies; and if all white in their bodies, yet if black-mouth'd, their ears and feet maintain the fame colour, are correfpondent tinctures not ordinarily failing in nature, which eafily $\mathrm{u}=$ nites the accidents of extremities, fince in fome generations the tranfmutes the parts themfelves, while in the Aurelian Metamorphofs the head of the canker becomes the Tayl of the Butterfly. Which is in fome way not beyond the contrivance of Art, in fubmerfions and Inlays, inverting the extremes of the plant, and fetching the root from the top, and allo imitated 
imitated in handfome columnary work, in the inverfion of the extremes; wherein the Capitel, and the Bafe, hold fuch near correlpondency.

In the motive parts of animals may be difcovered mutuall proportions; not only in thofe of Quadrupeds, but in the thigh-bone, legge, foot-bone, and claws of Birds. The legs of Spiders are made after a fefqui-tertian proportion, and the longlegs of fome locufts, double unto fome others. But the internodial parts of Vegetables, or fpaces between the joints, are contrived with more uncertainty; though the joints themfelves in many plants, maintain a regular number.

In vegetable compofure, the unition of prominent parts feems molt to anfwer the Apopbyjes or procelfes of Animall bones, whereof they are the produced parts or prominent explantations. And though in the parts of plants which are not ordained for motion, we do not expect correfpondent Articulations; yet in the fetting on of fome flowers, and feeds in their fockets, and the lineal commiffure of the pulpe of feverall feeds, 
The Quincunx Naturally Confidered. may be obferved fome thadow of the Harmony; fome fhow of the Gomphofis or mortis-articulation.

As for the Diarthrofis or motive Articulation, there is expected little Analogy, though long-ftalked leaves doe move by long lines, and have oblervable motions, yet are they made by outward impulfion, like the motion of pendulous bodies, while the parts themfelves are united by fome kinde of fymphyfes unto the ftock.

But ftanding vegetables, void of motive-Articulations, are not without many motions. For befide the motion of vegetation upward, and of radiacion unto all quarters, that of contraction, dilatation, inclination, and contortion, is difcoverable in many plants. To omit the rofe of Fericho, the ear of Rye, which moves with change of weather, and the Magical Spit, made of no rare plants, which windes before the fire, and rofts the bird without turning.

Even Animals near the Claffis of plants, feem to have the moft reftleffe motions. The Summer-worm of Ponds and plafh- 
Found often in fome form of redmaggot in the ftanding waters of Cifterns in the Sum.

mer. es makes a long waving motion; the hair-worm feldome lies ftill. He that would behold a very anomalous motion, may obferve it in the Tortile and tiring ftroaks of a Gatworms. 


\section{CHAP. IIII.}

A $S$ for the delights, commodities, $A$ myfteries, with other concernments of this order, voe are unwilling to fly them over, in the fhort deliveries of Virgil, Varro, or others, and fhall therefore enlarge with additionall ampliations.

By this pofition they had a juft pro= porrion of Earth, to fupply an equality of nourifhment. The diftance being ordered, thick or thin, according to the magnitude or vigorous attraction of the plant, the goodneffe, leanneffe, or propriety of the foyle, and therefore the zule of solon, concerning the territory of Atbens, not extendible unto all; allowing the diftance of fix foot unto com: mon Trees, and nine for the Figge and Olive.

They had a due diffofion of their roots on all or both fides, whereby they maintained fome proportion to $M$ theis 


\section{Cyrus-Garden, Or}

their height, in Trees of large radication. For that they ftrictly make gor' theit profundeur or-depth unto their height, according to common conceit, enentum and that expreflion of a Virgil, though verice ad confirmable from the plane Tree in Pliauras Axthereas, santum radice ad tarsare rendit.

$n y$, and fome few examples, is not to be expected from the generation of Trees almolt in any kinde, either of fide-fpreading, or tap-roots: Except we meafure them by lateral and oppofite diffufions; nor commonly to be found in minor or hearby plants; If we except Sea-holly, Liquorith, Sea-ruh, and fome others.

They had a commodious radiation in their growth; and a due expanfion of their branches, for thadow or delight. For trees thickly planted, do runne up in height and branch with no expanfion, thooring unequally or fhort, and thinne upon the neighbouring fide. And therefore T'rees are inwardly bare, and fpring, and leaf from the outward and Sunny fide of their branches.

Whereby they alfo avoided the pe-

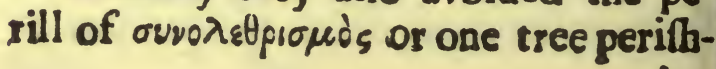


The Quincunx Miftically Confidered. $16_{3}$

ing with another, as it happeneth offtimes from the lick effluviums or entanglements of the roots, falling foul with each other. Obfervable in Elmes fet in hedges, where if one dieth the neighbouring Tree profpereth not long afier.

In this fituation divided into many intervals and open unto fix paffages, they had the advantage of a fair pertlation from windes, brufhing and clennfing their furfaces, relaxing and clofing their pores unto due perfpiration. For that they afford large efflaviwens perceptible from odours, diffuled at great diftances, is oblervable from Onyons out of the earth; which though dry, and kept until the fpring, as they thoor forth large and many leaves, do notably abate of their weight. And mint growing in glaffes of water, until it arriveth unto the weight of an ounce, in a thady place, will fometimes exhauft a pound of water.

And as they fend forth much, fo may they receive fomewhat in: For befide the common way and road of reception $\mathrm{M}_{2}$ 
by the root, there may be a refection and imbibition from without; For gentle thowrs refrefh plants, though they enter not their roots; And the good and bad effluviums of Vegetables, promote or debilitate each other. So Epithymum and Dodder, rootleffe and out of the ground, maintain themfelves upon Thyme, Savory, and plants, whereon they hang.And Ivy divided from the root, we have obferved to live fome years, by the cirrous parts commonly conceived but as tenacles and holdfaftsunto it. The ftalks of mint cropt from the root ftripped from the leaves, and fet in glaffes with the root end upward, \& out of the water, we have oblerved to fend forth fprouts and leaves without the aid of roots, and fcordium to grow in like manner, the leaves fet downward in water. To omit feverall Sea-plants, which grow on fingle roots from ftones, although in very many there are fide-fhoots and fibres, befide the faftening root.

By this open pofition they were fairly expofed unto the rayes of Moon and Sunce, to confiderable in the growth of 
The Quincunx Miftically Confidered. $16_{5}$

Vegetables. For though Poplars, Willows, and feverall Trees be made to grow about the brinks of Acharon, and dark habitations of the dead; Though fome plapts are content to grow in obfcure Wells; wherein alfo old Elme pumps afford fometimes long bufhy fprouts, not obfervable in any aboveground: And large fields of Vegetables are able to maintain their verdure at the bottome and Thady part of the Sea; yet the greateft number are not content without the actual rayes of the Sunne, but bend, incline, and follow them; As large lifts of folifequious and Sun-following plants. And fome ob. ferve the method of its motion in their owne growth and converfion twining towards the Weft by the South, as Bryony, Hops, Woodbine, and feveral kindes of Bindeweed, which we thall more admire; when any can tell us, they obferve another motion, and Twift by the North at the Astipodes. The fame plants rooted againft an erect North-wall full of holes, will finde a

$$
\mathrm{M}_{3}
$$

way 
166 Cyrus-Garden, Or

way through them to look upon the Sunne. And in tender plants from muftard feed, fown in the winter, and in a plot of earth placed inwardly againft a South-window, the tender ftalks of two leaves arofe not erect, but bending towards the window, nor looking much higher then the Meridian Sun. And if the pot were turned they would work themfelves into their former declinations, making their converfion by the Eaft. That the Leaves of the Olive and fome other Trees folftitially turn, and precifely tell us, when the Sun is entred Cancer, is fcarce expectable in any Climate; and Theophraftus warily obferves it; Yet fomewhat thereof is oblervable in our own, in the leaves of Willows and Sallows, fome weeks after the So:ftice. But the great Convolvalus or white-Hower'd Bindweed obferves both motions of the Sunne, while the flower ewifts Equinoctionally from the left hand to the right, according to the daily sevolution; The ftalk twineth ecliptically from the right to the left, according to the anqual converfion. 
The Quincunx Miftically Confidered $\quad 167$

Some commend the expofure of thefe orders unto the Weftern gales, as the moft generative and fructifying breath of heaven. Bue we applaud the Husbandry of Solomon, whereto agreeth the doctrine of Theophrastus. Arife O Northwinde, and blow thou South upon my garden, that the fpices thereof may tlow out; For the North-winde clofing the pores, and fhutting up the efflwiums, when the South doth after open and relax them; the Aromatical gummes do drop, and fweet odours fly actively from them. And if his garden had the fame fituation, which mapps, and charts afford it, on the Eaft fide of Ferufalem, and having the wall on the Weft; thefe were the windes, unto which it was well expored.

By this way of plantation they encreafed the number of their trees, which they loft in Quaternio's, and fquare-orders, which is a commodity infifted on by Varro, and one great intent of nature, in this pofition of flowers and feeds in the elegant formation of plants, and the former Rules obferved in naturall $M_{4}$ and 
and artificiall Figurations.

Whether in this order and one Tree in fome meafure breaking the cold, and pinching gufts of windes from the ther, trees will not better maintain their inward circles, and either efcape or moderate their excentricities, may alfo be confidered. For the circles in Trees are naturally concentricall, parallell unto the bark, and unto each o ther, till froft and piercing windes contract and clofe them on the weatherfide the oppofite femicircle widely enlarging, and at a comely diffance, which hindreth oftrimes the beauty and roundneffe of Trees, and makes the Timber leffe ferviceable; whiles the afcending juyce not readily paffing, fettles in knots and inequalities, And therefore it is no new courfe of Agriculture, to oblerve the native pofition of Trees according toNorth and South in their tranfplantations.

The fame is alfo obfervable underground in the circinations and fphrerical rounds of Onyons, wherein the cir. cles of the Orbes are ofttimes larger, 
The Quincunx Miftically Confidered $16 \mathrm{~g}$ and the meridionall lines ftand wider upon one fide then the other. And where the largeneffe will make up the number of planetical Orbes, that of $L v$ 220, and the lower planets excede the dimenfions of siturne, and the higher: Whether the like be not verified in the Circles of the large roots of Briony and Mandrakes, or why in the knotts of Deale or Firre the Circles are often eccentricall, although not in a plane, but vertical and right pofition, deferves a further enquiry.

Whether there be not fome irregularity of roundneffe in moft plants according to their pofition? Whether fome fmall compreffion of pores be not perceptible in parts which ftand againft the current of waters, as in Reeds, Bullsufhes, and other vegetables toward the ftreaming quarter, may allo be obferved, and therefore fuch as are long and weak, are commonly contrived into a roundneffe of figure, whereby the water preffeth leffe, and flippeth more fmoothly from them, and even in flags of flat-figured leaves, the greater part obvert 
obvert their tharper fides unto the current in ditches.

But whether plants which float upon the furface of the water, be for the moft part of cooling qualities, thofe which thoot above it of heating vertues, and why? whether Sargaffo for many miles floating upon the Weftern Ocean, or Sea-lettuce, and Phafganium at the bottome of our Seas, make gond the like qualities? Why Fenny waters afford the hotteft and fweeteft plants, as Calamus, Cyperus, and Crowfoot, and mudd caft out of ditches moft naturally produceth Arfmart, Why plants fo greedy of water fo little regard oyl? Why fince many feeds contain much oyle within them, they endure it not well without, either in their growth or production? Why fince Seeds thoot commonly under ground, and out of the ayre, thofe which are let fall in thallow glaffes, upon the furface of the water, will fooner fprout then thofe at the bottome? And if the water be covered with oyle, thofe at the bottome will hardly fprout at all, we have not 
The Quincurax Miftically Confidered.

room to conjecture.

Whether Ivy would not leffe offend the Trees in this clean ordination, and well kepe paths, might perhaps deferve the queftion. But this were a quxery only unto fome habitations, and little concerning Cyrus or the Babylonian territcry; wherein by no induftry Harpalus could make Ivy grow : And Alexander hardly found it about thofe parts to imitate the pomp of Bacchus. And though in thefe Northern Regions we are too much acquainted with one Ivy, we know too little of another, whereby we apprehend not the cxpreffions of Antiquity, the a Splenetick medicine of Galen, and the Emphafis of the Poet, in the $b$ beauty of the white lvy.

The like concerning the growth of alba.
Miffeltoe, which dependeth not only of the /pecies, or kinde of Tree, but much alfo of the Soil. And therefore common in fome places, not readily found in others, frequent in Frasce, not fo common in spain, and fcarce at all in the Territory of Ferraya : Nor eafily to be found where it is moft required

- Galen. de med. Secundum loc. b Hedere formofior alba. 
upon Oaks, leffe on Trees continually verdant. Athough in fome places the Olive efcapeth it not, requiting its detriment, in the delightfull view of its red Berries; as Clufsus obferved in Spain, and Belloniss about Hiernfaless. But this Parafiticall plant fuffers nothing to grow upon it, by any way of art; nor could we ever make it grow where nature had not planted it; as we have in vain attempted by inocculation and incifion, upon its native or forreign ftock. And though there feem nothing improbable in the feed, it hath not fucceeded by fation in any manner of ground, wherein we had no reafon to defpair, fince we reade of vegetable horns, and

tinfsbolen. how Rams horas will root about Goa.

But befides thefe rurall commodities, it cannot be meanly delectable in the variety of Figures, which thefe orders 0 pen, and clofed do make. Whileft every inclofure makes a Rhombus, the fi gures obliquely taken a Rhomboides, the intervals bcunded with parallell lines, and each interfection built upon 
The Quincunx Miftically Confidered.

a fquare, affording two Triangles or Pyramids vertically conjoyned; which in the ftriet Quincunciall order doe oppofitely make acute and blunt Angles.

And though therein we meet not. with right angles, yet every Rhombus containing four Angles equall unto two right, it virtually contains two right in every one. Nor is this ftrange unto fuch as obferve the naturall lines of Trees, and parts difpofed in them. For neither in the root doth nature affect this angle, which thooting downward for the ftability of the plant, doth beft effect the fame by Figures of Inclination; Nor in the Branches and ftalky leaves, which grow moft at acure angles; as declining from their head the root, and diminifhing their Angles with their altitude: Verified alfo in leffer Plants, whereby they better fupport themfelves, and bear not fo heavily upon the ftalk: So that while near the root they often make an Angle of feventy parts, the fprouts near the top will often come fhort of thirty 


\section{Cyrus-Garden, Or}

thirty. Enen in the nerves and mafter veins of the leaves the acute angle ruleth; the obtufe but feldome found, and in the backward part of the leaf, reflecting and arching about the ftalk. But why ofttimes one fide of the leaf is unequall unto the other, as in Hazell and Oaks, why on either fide the mafter vein the lelfer and derivative channels not directly oppofite, nor at equall angles, refpectively unto the adverfe fide, but thofe of one part do often exceed the other, as the Wallnut and many more deferves another enquiry.

Now if for this order we affect coniferous and tapering Trees, particularly the Cypreffe, which grows in a conicall figure; we have found a Tree not only of great Ornament, but in its Effentials of affinity unto this order. A folid Rhombus being made by the converfion of two Equicrurall Cones, as Archimedes hath defined. And thefe were the common Trees about Babylon, and the Eaft, whereof the Ark was made; and Alexander found no Trees fo accomodable to build his $\mathrm{Na}$ - 


\section{The QuincunxMiftically Confidered. I75}

vy; And this we rather think to be the Tree mentioned in the Canticles, which ttricter Botanology will hardly allow to be Camphire.

And if delight or ornamentall view invite a comely difpofure by circular amputations, as is elegantly performed in Hawthorns; then will they anfwer the figures made by the converfion of a Rhombus, which maketh two concentricall Circles; the greater circumference being made by the leffer angles, the leffer by the greater.

The Cylindrical figure of Trees is virtually contained and latent in this order. A Cylinder or long round being made by the converfion or turning of a Parallelogram, and moft handfomely by a long fquare, which makes an equall, ftrong. and lafting figure in Trees, agreeable unto the body and motive parts of animals, the greateft number of Plants, and almoft all roots, though their ftalks be angular, and of many corners, which feem not to follow the figure of their Seeds; Since many angular Seeds fend forth round ftalks, and fphxricall feeds 


\section{Cyrus-Garden, Or}

arife from angular fpindles, and many rather conform unro their Roots, as the round ftalks of bulbous Roors, and in nberous Roots ftemmes of like figure. But why fince the largeft number of Plants maintain a circular Figure, there are fo few with teretous or lunground leaves; why coniferous Trees are tenuifolious or narrowleafed, why Plants of few or no joynts have commonly round ftalks, why the greateft number of hollow ftalks are round ftalks; or why in this variety of angular ftalks the quadrangular moft exceedeth, were too long a fpeculation; Mean while obvious experience may finde, that in Plants of divided leaves above, nature ofien beginneth circularly in the two firft leaves below, while in the fingular plant of Ivy, the exercifeth a contrary Geometry, and beginning with angular leaves below, rounds them in the upper branches.

Nor can the rows in this order want delight, as carrying an afpect anfwerable unto the dipteros brpathros, or double order of culumns open above; the 
The Quincunx Miftically Confidered.

oppofite ranks of Trees ftanding like pillars in the Cavedia of the Courts of famous buildings, and the Portico's of the Templa fabdialia of old; Somewhat imitating the Periftylia or Cloyfter buildings, and the Exedra of the Ancients, wherein men difcourfed, walked and exercifed; For that they derived the rule of Columnes from Trees, efpecially in their proportionall diminutions, is illuftrated by Vitrweviss from the thafts of Firre and Pine. And though the inter-arboration do imitate the Areostylos, or thin order, not ftrictly anfwering the proportion of intercolumniations; yet in many Trees they will not exceed the intermiffion of the Columnes in the Court of the Tabernacle; which being an hundred cubits long, and made up by twenty pillars, will afford no leffe then intervals of five cubits.

Befide, in this kinde of arpect the fight being not diffufed but circumfcribed between long parallels and the $\bar{\varepsilon} \pi i \sigma x b-$ $a^{\prime} \sigma e^{\prime}{ }^{\prime} s$ and adumbration from the branches, it frameth a penthoufe over the eye, and maketh a quiet vifion: And 


\section{$178 \quad$ Cyrus-Garden, Or}

therefore in diffufed and open afpects, men hollow their hand above their eye, and make an artificiall brow, whereby they direct the difperfed rayes of fight, and by this thade preferve a moderate light in the chamber of the eye ; keeping the papilla plump and fair, and not contracted or fhrunk as in light and vagrant vifion.

And therefore providence hath arched and paved the great houfe of the world, with colours or mediocrity, that is, blew and green, above and below the fight, moderately terminating the acies of the eye. For moft plants, though green above ground, maintain their Originall white below it, according to the candour of their feminall pulp, and the rudimental leaves do firft appear in that colour; obfervable in Seeds fprouting in water upon their firft foliation. Green feeming to be the firft fupervenient, or above-ground complexion of Vegetables. feparable in many upon ligature or inhumation, as Succory, Endive, A rtichoaks, and which is alfo loft upon fading in the Autumn. 
The Quincunx Miftically Confidered.

And this is alfo agreeable unto water it felf, the alimental vehicle of plants, which firft altereth into this colour; And containing many vegetable feminalities, revealeth their secds by greenneffe : and therefore fooneft expected in rain or ftanding water, not eafily found in diftilled or water ftrongly boiled; wherein the Seeds are extinguifhed by fire and decoction. and therefore laft long and pure without fuch alteration, affording neirher uliginous coats, gnatworms, Acari, hair-worms, like crude and common water; And therefore molt fit for wholfome beverage, and with malt makes Ale and Beer without boyling. What large water-drinkers fome Plants are, the Canary-Tree and Birches in fome Northern Countries, drencting the Fields about them do fufficiently demonftrate How water it felf is able to maint ain the growth of Vegetables, and withnut extinction of their generative or medicall verrues; Befide the experiment of Helmonts tree, we have found. in fome which have lived fix years in glafles, The feeds of Scurvy-graffe

$$
N=
$$




\section{Cyrus-Garden, Or}

growing in waterpots, have been fruit. full in the Land; And A Aarum after a years fpace, and once cafting its leave: in water, in the fecond leaves, hath. handlomely performed its vomiting ope. ration.

Nor are only dark and green colors, bu thades and fhadows contrived through the great Volume of nature, and trees ordained not only to protect and thadow others, bur by their fhades and fhadowing parts, to preferve and cherifh them. felves. The whole radiacion or branchings thadowing the ftock and the root, the leaves, the branches and fruit, too much expofed in the windes and fcorching Sunne. The calicular leaves inclofe the tender flowers, and the flowers themfelves lye wrapt about the feeds, in their rudiment and firft formations, which being advanced the flowers fall away; and are therefore contrived in variety of figures, beft fatisfying the intention; Handfomely obfervable in hooded and gaping flowers, and the Butterfly bloomes of leguminous plants, the lower leaf clofely involving the ru- 


\section{Tbe Quincunx Miftically Confidered $18 \mathrm{I}$}

dimental Cod, and the alary or wingy divifions embracing or hanging over it.

But Seeds themfelves do lic in perpetual thades, either under the leaf, or thut up in coverings; And fuch as lye bareft, have their husks, skins, and pulps about them, wherein the nebbe and generative particle lyeth moift and fecured from the injury of Ayre and Sunne. Darkneffe and light hold interchangeable dominions, and alternately rule the feminal ftate of things. Light unto a Plato is darkneffe unto fupiter. Legions of feminall ldaa's lye in their fecond Chaos and Orcus of Hipocrat "s; till putting on the habits of their forms, they thew themfelves upon the ftage of the world, and open dominion of fove. They that held the Stars of heaven were but rayes and Hafhing glimples of the Empyreall light, through holes and perforations of the upper heaven, took of the natural thadows of ftars, while according to better difcovery the poor Inhabitants of the Moone have but 2 Lux orco, tenchra fovi, rencibre orco, lux fovi. Hip. pucr. de diata.

a polary life, and muft paffe half their

$$
\mathrm{N}_{3} \text { dayes }
$$

S. Hevelii Seleno. graphia. 
dayes in the thadow of that Luminary.

Light that makes things feen, makes fome things invifible, were it not for darkneffe and the thadow of the earth, the nobleft part of the Creation had remained unfeen, and the Stars in heaven as invifible as on the fourth day, when they weie created above the Horizon, with the Sun, or there was not an eye to behold them. The greateft myftery of Religion is expreffed by adumbration, and in the nobleft part of Jewifh Types, we finde the Cherubims thadowing the Mercy-feat: Life it lelf is but the fhadow of death, and fouls departed but the thadows of the living: All things fall under this name. The Sunne it felf is but the dark fimulacbrum, and light but the fhadow of God.

Laftly, It is no wonder that this Quincunciall order was firft and ftill affected as gratefull unto the Eye: For all things are feen Quincuncially; For at the eye the Pyramidal rayes from the object, receive a decuffation, and fo ftrike a fecond bafe upon the Retina or hinder 


\section{The Quincunx Miftically Confidered. $\quad 18_{3}$}

hinder coat, the proper organ of Vifion; wherein the pictures from objects are repreferted, anfwerable to the paper, or wall in the dark chamber; after the decuffation of the rayes at the hole of the hornycoat, and their refraction upon the Chriftalline humour, anfwering the foramen of the window, and the convex or burning-glaffes, which refract the rayes that enter it. And if ancient Anatomy would hold, a like difpolure there was of the optick or vifual nerves in the brain, wherein Antiquity conceived a concurrence by decuffation. And this not only obfervable in the Laws of direct Vifion, but in fome part allo verified in the reflected rayes of fight. For making the angle of incidence equal to that of reflexion, the vifuall raye returneth Quincuncially, and after the form of $\mathrm{aV}$, and the line of reflexion being continued unto the place of vifion, there arifeth a femi-decuffation, which makes the object feen in a perpendicular unto it felf, and as farre below the reHectent, as it is from it above; oblerva-

$$
\text { N } 4
$$

ble 


\section{Cyrus-Garden, Or}

ble in the Sun and Moon beheld in water.

And this is alfo the law of reflexion in moved bodies and founds, which though not made by decuffation, obferve the rule of equality between incidence and reflexion; whereby whifpering places are framed by Ellipticall arches laid fide-wife; where the voice being delivered at the focus of one extremity, obferving an equality unto the angle of incidence, it will reflect unto the fous of the other end, and fo efcape the ears of the ftanders in the middle.

A like rule is obferved in the reflection of the vocull and fonorous line in Ecchoes, wrich cannot therefore be heard in all ftations. But happening in woody plantations, by waters, and able to return fome words; if reacht by a pleafant and well-dividing voice, there may be heard the lofteft notes in nature.

And this rot-only verified in the way of 'erce, bui in animall and intelleetuall receptions. Things entring upon the intellect by a Pyramid from without, 
The Quincunx Miftically Confidered. $\quad 185$ and thence into the memory by another from within, the common decuffation being in the underftanding as is delivered by a Bovillus. Whether the intellectual and phantaftical lines be not thus rightly difpofed, but magnified diminifhed, diftorted, and ill placed in the $\mathrm{Ma}$ thematicks of fome brains, whereby they have irregular appiehenfions of things, perverted notions, conceptions, and incurable hallucinations, were no unpleafant fpeculation.

And if Ægyptian Philofophy may obtain, the fcale of influences was thus difpofed, and the geniall fpirits of both worlds, do trace their way in afcending and defcending Pyramids, myftically apprehended in the Letter $X$, and the open Bill and ttradling Legges of a Stork, which was imitated by that Character.

Of this Figure Plato made choice to illuftrate the motion of the foul, both of the world and man; while he delivereth that God divided the whole conjunction length-wife, according to the figure of a Greek $X$, and then turning it about reflected it into a circle; By the circle im-

plying

- Car. Bovillus de intellodu. 
plying the uniform motion of the firft Orb, and by the right lities, the planetical and various motions within it. And this alfo with application unto the foul of man, which hath a double afpect, one right, whereby it beholdeth the body, and objects without; another circulat and reciprocal, whereby it beholdeth it felf. The circle declaring the motion of the indivifible foul, fimple, according to the divinity of its nature, and returning into it felf; the right lines refpecting the motion pertaining unto fenfe, and vegctation, and the central decuffation, the wondrous connexion of the feverall faculties conjointly in one fubftance. And fo conjoyned the unity and duality of the foul, and made out the three fubftances fo much confidered by him; That is, the indivifible or divine, the divifible or corporeal, and that third, which was the $s y$ fafis or harmony of thofe two, in the myftical decuffation.

And if that were clearly made' out which Fuftin Martyr took for granted, this figure hath had the honour to charaeqcrize and notifie our bleffed Saviour, as 
The Quincunx Miftically Confidered $\quad 187$ he delivereth in that borrowed expreffion from Plato; Decu[avit eums in univeryo, the hint whereof he would have Plato derive from the figure of the brazen Serpent, and to have miftaken the Letter $\mathrm{X}$ for $T$, whereas it is not improbable, he learned thefe and other myftical expreffions in his Learned Obfervations of $\mathbb{E}$ gypt, where he might obvioufly behold theMercurial characters, the handed croffes, and other my fteries not throughly underftood in the facred Letter X, which being derivative from the Stork, one of the ten facred animals, might be originally Æggptian, and brought into Greece by cadmus of that Countrey. 


\section{CH A P. V.}

TO enlarge this contemplation unto all the myfteries and fecrets, act comodable unto this number, were in excufable Pythagorifme, yet cannot omit the ancient conceit of five furna

- dika. med the number of a juftice; as juftly dividing between the digits, and - - hanging in the centre of Nine, deferi-

- - bed by fquare numeration, which angu-

- - larly divided will make the decuffated number; and fo agreeable uuto the Quincunciall Ordination, and rowes divided by Equality, and juft decorum, in the whole com-plantation; And might be the Originall of that com. mon game among us, wherein the fifth place is Soveraigne, and carrieth the chief intention. The Ancients wifely inftruding youth, even in their recreations unto virtue, that is, early to drive 
The QuincunxMiftically Confidered. 189

at the middle point and CentralSeat of juftice.

Nor can we omit how agreeable unto this number an handfome divifion is made in Trees and Plants, fince Phstarch, and the Ancients have named it the Divifive Number, jufly dividing the Entities of the world, many remarkable things in it, and alfo comprehending the a generall divifion of Ve-

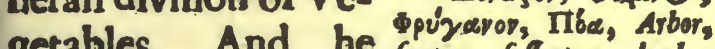
getables. And he frutex, suffrutex, berba, that confiders how and that fifth which commoft bloffomes of prehendech the funciand

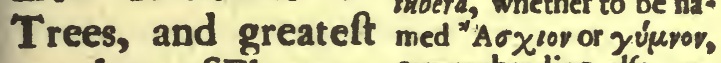
number of Flowers, comprehendipg allo cano confift of five leaves; cords, of fo many yards and therein doth reft length.

the fetled rule of

nature; So that in thofe which exceed there is often found, or eafily made a variety; may readily difcover how nature refts in this number, which is indeed the firft reft and paufe of numeration in the fingers, the naturall Organs thereof. Nor in the divifion of the feet of perfect animals doth nature ex- 
ceed this account. And even in the joints of feet, which in birds are moft multiplied, furpaffeth not this number ; So progreffionally making them out in many, that from five in the fore-claw the defcendeth unto two in the hindemolt; And $f o$ in fower feet makes up the number of joynts, in the five fingers or toes of man.

Not to omit the Quintuple Section - Elleipfis, of a a Cone, of handfome practife in parabola. Hyperbole, Circulus, Iriangalum. Ornamentall Garden-plors, and in $f($ me way difcoverable in fo many works of Nature; In the leaves, fruits, and feeds of Vegetables, and fcales of fome Fifhes, fo much confiderable in glaftes, and the optick doctrine; wherein the learned may confider the Cryftalline humour of the eye in the cuttle filh and Loligo.

He that forgets not how Antiquity named this the Conjugall or wedding number, and made it the Embleme of the molt remarkable conjunction, will conceive it duely appliable unto this handfome Oeconomy, and vegetable combination; May herce apprebend 


\section{The Quincunx Miftically Confidered. $19 \mathrm{x}$}

the allegoricall fence of that obfcure expreffion of a Hefiod, and afford no im- a тi probable reafon why Plato admitted his idef nuppiNuptiall guefts by fives, in the kindred of the ${ }^{b}$ married couple.

And though a harper myftery might as multas.

Rhodig.

b Plato de

leg. 6.

be implied in the Number of the five wife and foolith Virgins, which were to meet the Bridegroom, yet was the fame agreeable unto the Conjugall Number, which ancient Numerifts made out by two and three, the firft parity and imparity, the active and paffive digits, the materiall and formall principles in generative Societies. And not difcordant even from the cuftomes of the Romans, who admitted but $\mathrm{c}$ five Torches in their Nuptiall folemnities. Whether there were any myftery or not implied, the moft gec Plutarcó problem. Rom.I. nerative animals were created on this day, and had accordingly the largeft benediction: And under a Quintuple confideration, wanton Antiquity confidered the Circumftances of generation, while by this number of five they 
naturally divided the Nectar of the fifth Planet,

The fame number in the Hebrew myfteries and Cabaliftical accounts was d Archans. the d charadter of Generation; declades, Cubal. red by the Letter $H e$, the fifth in their Alphabet; According to that Cabalifticall Dogma: If Abram had not had this Letter added unto bis Name he had remained fruitleffe, and without the power of generation: Not onely becaufe hereby the number of his Name attained two hundred fourty eight, the number of the affirmative precepts, but becaufe as increated natures there is a male and female, fo in divine and intelligent productions, the mother of Life and Fountain of fouls in Cabalifticall Techuology is called Binab; whofe Seal and Character was He. So that being fterill before, he recived the power of generation from that meafure and manfion in the Archetype; and was made conformable unto Birab. And upon fuch involved Eod into confiderations, the e ten of Sarai was
He. ex- 


\section{The Quincuax Miftically Confidered. 193}

exchanged into five, If any (ball look upon this as a ftable number, and fitly appropriable unto Trees, as Bodies of Reft and Station, he hath berein a great Foundation in nature, who obferving much variety in legges and motive Organs of Animals, as ?wo, four, fix, eight, twelve, fourteen, and more, hath paffed over five and ten, and affigned them unto none, ior very few, as the Phalangium monftrofum Braflitanum, Clufii do Jac. de Laet. Cur. poster. America Defcript. If perfectly defcribed. And for the ftability of this Number, he fhall not want the fphericity of its nature, which multiplied in it felf, will return into its own denomination, and bring up the reare of the account. Which is allo one of the Numbers that makes up fthe myfticall Name of God, which confifting of Letters denoting all the fphrericall Numbers, ten, five, and fix; Emphatically fets forth the Notion of Trismegiftus, and that intelligible Sphere, which is the Nature of God. 
Many Expreffions by this Number occurre in Holy Scripture, perhaps unjuftly laden with myfticall Expofitions, and little concerning our order. That the Ifraelites were forbidden to eat the fruit of their new planted Trees, before the fifth yeare, was very agrceable unto the naturall Rules of Husbandry: Fruits being unwholfome and lath, before the fourth, or fifth Yeare. In the fecond day or Feminire part of five, there was added no approbation. For in the third or mafculine day, the fame is twice repeated; and a double benediction inclofed both Creations, whereof the one, in fome part was but an accomplifhLev 6 . ment of the other. That the Trefpaffer was to pay a fifth part above the head or principall, makes no fecret in this Number, and implied no more then ore part abcve the principall; which teing confidered in four parts, the additienall forfeit mult bear the Name of a fift. The five golden mice had flainly their determination from 
The Quincunx Miftically Confidered. 195

the number of the Princes; That five thould put to Highe an hundred mighe have nothing myftically implyed; conGidering a rank of Souldiers could fcarce confift of a leffer number. Saint paul had rather fpeak five words in a known then ten thoufand in an unknowne tongue: That is as little as could well be fpoken. A fimple propofition confifting of three words and a complexed one not ordinarily thort of five.

More confiderable there are in this myfticall account, which we muft not infift on. And therefore why the radicall Letters in the Pentateuch, Thould equall the number of the Souldiery of the Tribes; Why our Saviour in the Wilderneffe fed five thonfand perfons with five Barley Loaves, and again, but four thoufand with no leffe then feven of Wheat? Why Jofeph defigned five changes of Rayment unto Benjamin? and David took juft five pibbles out of the Brook againft the Pagan Champion? We leave it unto Arithmet-

Tíraes tives four $\mathrm{O}_{2}$ cail and one,nr five. Scalig. 
call Divinity, and Theologicall explanation.

Yet if any delight in new Problemee, or think it worth the enquiry, whether the Griticall Phyfician hath rightly hit the nominall notation of Quinque; Why the Ancients mixed five or three but not four parts of water unto their Wine: And Hippocrazes obferved a fifth proportion in the mixture of water with milk, as in Dy/enteries and bloudy fluxes. Under what abftrufe foundation Aftrologers do Figure the good or bad Fate from our Children, 'Axasi in a good Fortune, or the fifth houfe $\pi u x x^{n}$ or bona fortune the name of their Celeftiall Schemes. Whether the Ixgyptians defcribed a Starre by a of the fifth Figure of five points, with reference Conjunct, oppofite, rextile, trigonal, tezragonal. unto the ${ }^{b}$ five Capitall alpects, whereby they tranfmit their Influences, or abftrufer Confiderations? Why the $\mathrm{Ca}$ balifticall Dattors, who conceive the whole Sepbiroth, or divine emanations to have guided the ten-fringed Harp of David, whereby he pacified the evil fpirit of saul, in ftria numeration doe begin 


\section{The Quinounx Miftically Canfidered.}

begin with the Perihypate Mefon, or If fa ut, and fo place the Tiphereth anfwering $C$ fol fa ut, upon the fifth ftring: Or whether this number be oftner applied unto bad things and ends, then good in boly Scripture, and why? He may meet with abltrufities of no ready refolution.

If any thall queftion the rationality of that Magick, in the cure of the blind man by serapis, commanded to place five fingers on his Altar, and then his hand on his Eyes? Why fince the whole Comoody is primarily and naturally comprifed in c four parts, and Antiquity permitted not fo many perfons to Ipeak in one Scene, yet would not comprehend the fame in more or leffe then five acts? Why amongft Seaftarres nature chiefly delightoth in five points? And fince there are found fome of no fewer then twelve, and fome of feven, and nine there are fow or none difcovered of fix or eight ? If any thall enquire why the Flowers of Rive properly confift of fourLeaves, The firft and

$$
\mathrm{O}_{3} \text { third }
$$

crieg.7a. s, initrots, vódseas, eflaseopit: 


\section{Cyrus-Garden, Or}

third Flower have five? Why fince vnifoli- many Flowers bave one leaf or ${ }^{d}$ none, um,nulli- as Scaliger will have it, diverfe three, folivm. and the greateft number confift of five divided from their bottomes; there are yet fo few of two: or why nature generally beginning or fetting out with two oppofite leaves at the Root, doth fo feldome conclude with that order and number at the Flower? he thall not paffe his hours in vulgar fpeculations.

If any thall further quxry why magneticall Philolophy excludech decuffations, and needles rranfverfy placed do naturally diftract their verticities? Why Geomancers do imitate the Quintuple Figure, in their Mother Characters of Acquifition and Amiffion, Uce. fomewhat anfwering the Figures in the Lady or fpeckled Beetle? With what Equiry, Chiromantical conjecturers decry thefe decuffations in the Lines and Mounts of the hand? What that decuffated Figure intendeth in the medall of Alexander the Great? Why the Goddeffes fit commorly 


\section{The Quincunx Miftically Confidered 199}

monly croffe-legged in ancient draughts, Since 7 uno is defcribed in the fame as a veneficial pofture to hinder the birth of Hercules? If any thall doube why at the Amphidromicall Feafts, on the fifth day after the Childe was born prefents were fent from friends, of Polipuffes, and Curtle-filhes? Why five mutt be only left in that Symbolicall mutiny among the men of Cadmus? Why Protexs in Homer the Symbole of the firlt matter, before be fetled himfelf in the midt of his Sea-monfters, doch place them out by fives? Why the fifth years Oxe was acceptable Sacrifice unto Jupiser? Or why the Noble cantoninus in fome fence doth call the foul it felf a Rhombus? He Thall not fall on trite or triviall difquifitions. And thefe we in vent and propofe unto acuser enquirers, naufeating crambe verities and queftions over-queried. Flat and flexible rruths are beat out by every hammer; But $V u l$. can and his whole forge fureat to work our Achiller his armour. A large field is jet left unto tharper difcerners to en-

$$
\mathrm{O}_{4}
$$

large 


\section{Cyrus.Gardem, Or}

large upon this order, to fearch out the quasernio's and figared draughts of this nature, and moderating the ftudy of names, and meer nomenclature of plants, to erect generalities, difclofe unobferved proprieties, not only in the vegetable Thop, but the whole volume of nature; affording delightful Truths, confirmable by fenfe and ocular Obfervation, which feems to me the fureft path, to trace the Labyrinth of Truth. For though difcurfive enquiry and rationall conjeeture, may leave handfome gaftes and flefh-wounds; yet without conjunction of this expect no mortal or dif-

3 Fyades near the Forizon abour midnight, at that time. patching blows unto errour.

But the a Quincunx of Heaven runs low, and 'ris time to clofe the five parts of knowledge; Weare unwilling to spin out our awaking thoughts into the phantafmes of fleep, which often continaeth prrocogitations; making Cables of - De Inform. Cobwebbes and Wilderneffes of handniis. - Artemodo. fome Groves. Befide b Hippocrates hath res \& A pomazar. fpoke fo little and the $c$ Oneirocriticall Mafters, haveleft fuch frigid Interpretations 


\section{The Quincunx Miftically Confidered. 20I}

tations from plants, that there is little encouragement to dream of Paradife it felf. Nor will the fweeteft delight of Gardens afford much comfort in Ileep; wherein the dulneffe of that fenfe Thakes hands with delectable odours; and though in the $\mathrm{d}$ Bed of Cleopatra, a strewed can hardly with any delight raife up the ghoft of a Rofe.

Night which Pagan Theology could make the daughter of Cheos, affords no advantage to the defcription of order : Although no lower then that Maffe can we derive its Genealogy. All things began in order, fo thall they end, and fo thall they begin again; according to the ordainer of order and myftical Mathematicks of the City of Heaven.

Though somnes in Homer be fent to rowfe up Agsmemnon, I finde no fuch effects in thefe drowfy approaches of 1 cep. To keep our eyes open longer were but to act our Astipodes. The Hunt fimen are up in America, and they are already paft their firft lleep in Perffa, But who can be drow- 
drowfie at that howr which freed us from everlafting fleep? or have flumbring thoughts at that time, when Aleep it felf muft end, and as fome conjecture all thall awake again?

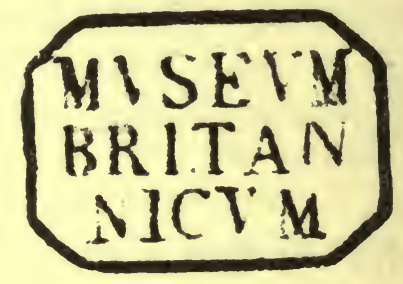

$$
\text { FI } ᄌ I s .
$$




\section{THE \\ STATIONER \\ TO THE \\ R E A D E R.}

T Cannot omit to advertife, that a Book was publifhed not long fince, Entituled, Natures Cabinet Unlockt, bearing the Name of this Authour: If any man have been benefited thereby this Authour is not fo ambitious as to challenge the honour thereof, as having no hand in that Work. To diftinguifh of true and fpurious Pecces was the $\mathbf{O}$ riginall Criticifme, and fome were fo handfomely counterfeited, that the Entitled Authours needed not to difclaime them. But 
But fince it is fo, that either he muft write himfelf, or Others will write for him, I know no better Prevention then to ad his own part with leffe intermif fion of his Pen.

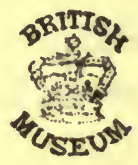

Books 


\section{Books Printed for Hen. Broome at the Gun in Ivy-Lane.}

The Souls conflict, Being Eight Sermons, fix whereof were preached at $O x f o r d$. The 2weens Excbanga, A Comedy, By Rechard Brome.

Two E\ays of Love and CAsarriage. The Grand Impoftor Examined, Or, tbe life and Triall of James Nayler.

The Souls Tournkey, Being a Conference betwixt $\mathrm{M}^{\mathrm{r}}$ Hanum and $\mathrm{M}^{\mathrm{r}}$ Tuke Moderator of Gr. Coll. in London.

Books now in the Preße wobicb will fbortly be extant.

The Affinity of facred Liturgies, By Hamon LEftrange, Efq.

Five New Comedies which were never before publifht, By Richard Brome. A Learned and much defired Commentary on the robole Epiftle to the Pbilippians, By Natb. Tucker Late Preacher of the Gorpel at Portfmouth. 


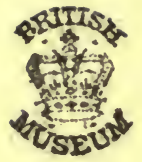




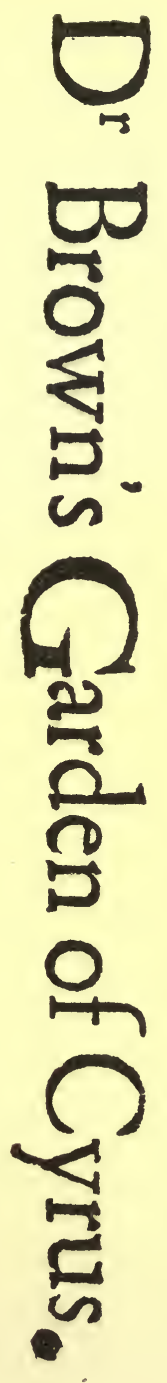





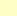

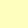




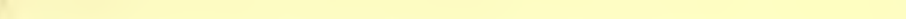


-

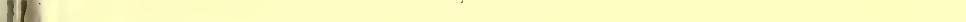

1 
$-$ 

. 

PR

3327

A 65

$1658 \mathrm{a}$
Browne, Sir Thomas

Hydriotaphia

\section{FEB 231990 .}




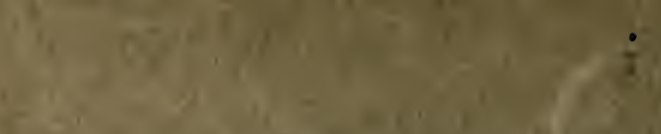

72,1

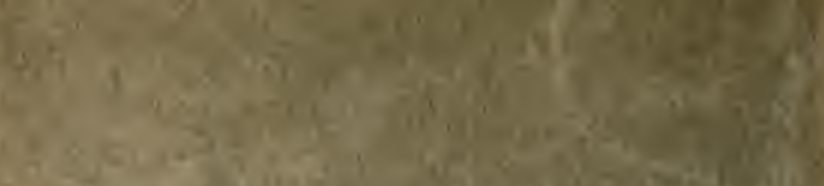

r.

B.

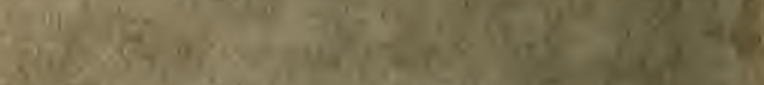
What ating

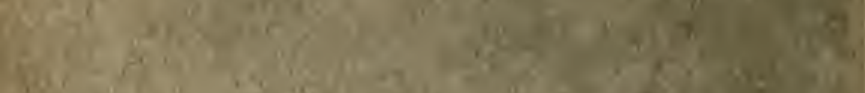

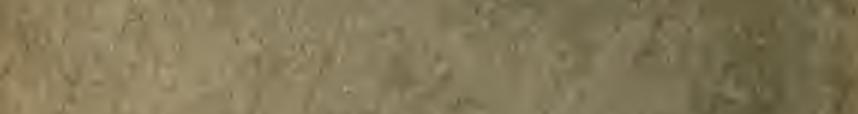

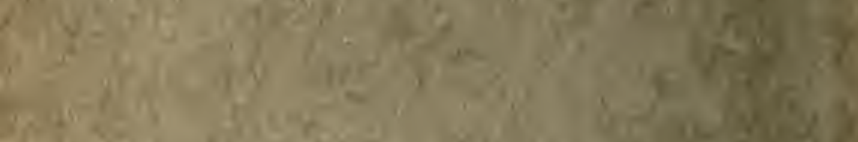

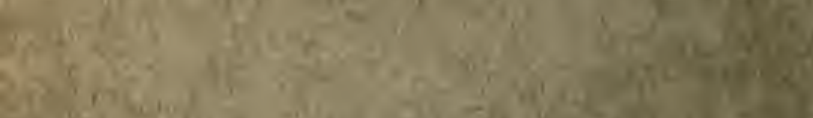

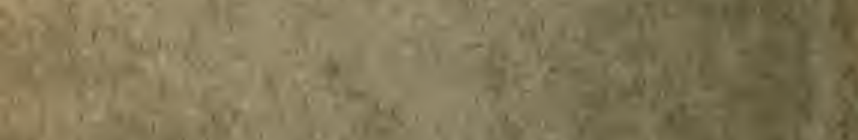

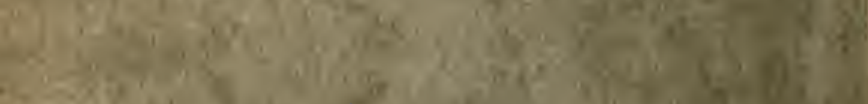

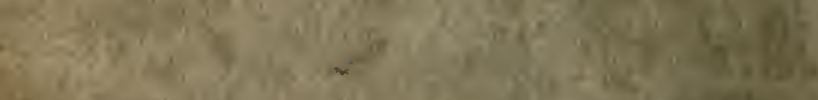

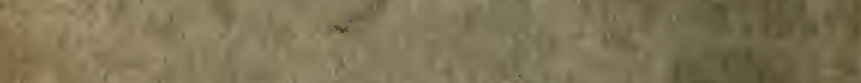

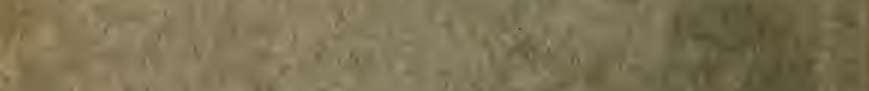

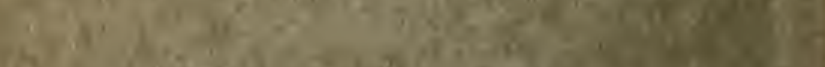

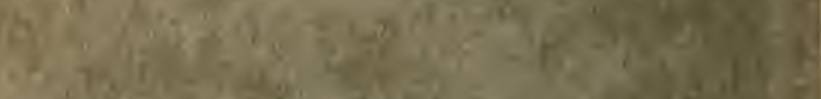

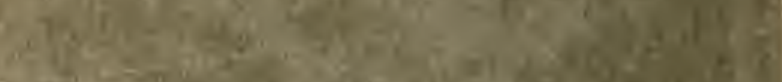

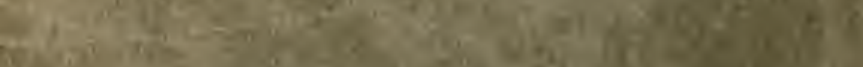

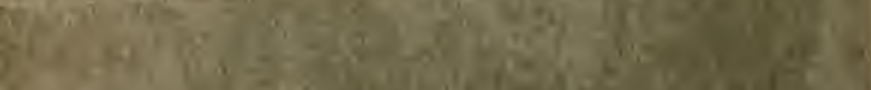

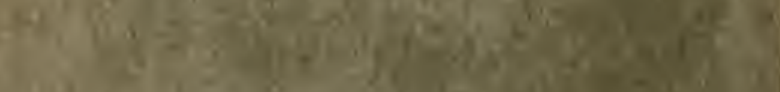

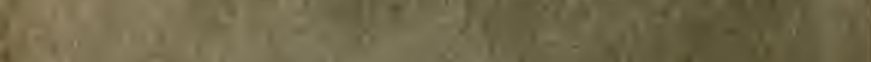

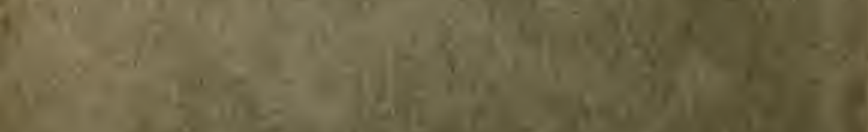

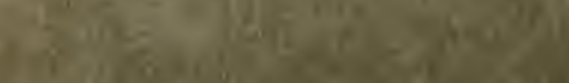
- 